Celina Pereira

\title{
MEDINDO A GOVERNABILIDADE NO BRASIL: \\ O presidencialismo de coalizão nos governos FHC, Lula e Dilma
}


Celina Pereira

\section{MEDINDO A GOVERNABILIDADE NO BRASIL: \\ O presidencialismo de coalizão nos governos FHC, Lula e Dilma}

Dissertação apresentada ao Programa de Pós-Graduação em Ciência Política, da Universidade de Brasília, como parte dos requisitos para obtenção do título de Mestre em Ciência Política.

Linha de Pesquisa: Política e Instituições

Orientador: Prof. Dr. Denilson Bandeira Coêlho 
Celina Pereira

\section{MEDINDO A GOVERNABILIDADE NO BRASIL: O presidencialismo de coalizão nos governos FHC, Lula e Dilma}

Dissertação submetida ao Programa de Pós-Graduação em Ciência Política, da Universidade de Brasília, como parte dos requisitos para obtenção do título de Mestre em Ciência Política.

Aprovada em 30 de março de 2017.

\section{Banca Examinadora:}

Prof. Dr. Denilson Bandeira Coêlho - Orientador

Universidade de Brasília - UNB, IPOL

Prof. Dr. Fernando de Barros Filgueiras - Examinador externo

Universidade Federal de Minas Gerais - DCP, UFMG

Escola Nacional de Administração Pública - ENAP

Prof. Dr. Rafael Silveira e Silva - Examinador externo Instituto Legislativo Brasileiro - ILB 


\section{DEDICATÓRIA}

Ao Chico e ao Beto, meus maiores mestres da Ciência Política. 


\section{RESUMO}

Este trabalho investiga a recente crise político-institucional brasileira, marcada pelo tensionamento da relação entre governo e Congresso. Analisa-se o período entre 1995 e 2016, que compreende os dois mandatos de Fernando Henrique Cardoso, de Luís Inácio Lula da Silva e de Dilma Rousseff. Para isso, o estudo propõe o que denomina "hemograma da governabilidade", composto por 13 (treze) indicadores e diversos dados relativos ao período. Os resultados demonstram distintos graus de governabilidade nas gestões presidenciais, com menores níveis nos governos Dilma, sobretudo no segundo mandato. A partir desses achados de pesquisa, das bases teóricas do presidencialismo de coalizão e da literatura sobre perfis presidenciais, defende-se a existência de importante relação, no caso brasileiro, entre o estilo de governar do núcleo duro do Executivo e a governabilidade.

Palavras-chave: Presidencialismo de coalizão - Governabilidade - Crise política Instituições - Atores - Hemograma da governabilidade - Perfil presidencial - Núcleo duro 


\begin{abstract}
This study investigates the recent Brazilian political-institutional crisis, marked by the tensions between the government and the Congress. For this, the phenomena of the governability is analysed from 1995 to 2016, which includes the two mandates of Fernando Henrique Cardoso, Luis Inácio Lula da Silva and Dilma Rousseff. The work proposes the so-called "diagnostic test of governability", composed by 13 (thirteen) indicators and different data for the period. The results indicate different degrees of governability in presidential administrations, with lower levels in Dilma's governments, especially in the second term. Based on these research findings, the theoretical bases of coalitional presidentialism and the literature on presidential styles, the study argues for the existence of an important relationship, in the case of Brazil, between the center of government profile and the governability.
\end{abstract}

Keywords: Coalitional presidentialism - Governability - Political crisis - Institutions Actors - Diagnostic test of governability - Presidential style - Center of government 


\section{LISTA DE TABELAS}

Tabela 1 - Ondas explicativas do presidencialismo de coalizão

Tabela 2 - Situação e quórum para deliberação das votações nominais, por tipo de proposição 43

Tabela 3 - Dimensões e indicadores de governabilidade 45

Tabela 4 - Composição partidária dos gabinetes, no início e fim dos mandatos, de 1995 a 2016

Tabela 5 - Tempo médio de permanência dos ministros titulares, por mandato, de 1995 a 2016

Tabela 6 - Ministros responsáveis pela articulação com o Congresso, por mandato, de 1995 a 2016

Tabela 7 - Taxa de fracionalização da Câmara dos Deputados, por mandato, de 1982 a 2006

Tabela 8 - Resultado do hemograma da governabilidade 75

\section{LISTA DE GRÁFICOS}

Gráfico 1 - Número de propostas enviadas ao Congresso, por mandato, de 1995 a 2016

Gráfico 2 - Taxa de participação do Executivo, por mandato, de 1995 a 2016. 47

Gráfico 3 - Ondas explicativas do presidencialismo de coalizão 48

Gráfico 4 -Taxa de sucesso do Executivo, por mandato, de 1995 a 2016 .49

Gráfico 5 - Taxa de dominância do Executivo, por mandato, de 1995 a 2016 .50

Gráfico 6 -Taxas de participação, sucesso e dominância do Executivo, por mandato, de 1995 a 2016.

Gráfico 7 - Número de vetos por ano, de 1995 a 2016 .52

Gráfico 8 - Número de vetos por ano, de 1995 a 2016 .53

Gráfico 9 - Percentual de conflito em medidas provisórias, por mandato, de 1995 a 2016 .55

Gráfico 10 - Número de deputados da coalizão, por mandato, de 1995 a 2016 .56

Gráfico 11 - Proporção entre o número de deputados da coalizão e o total de deputados, no fim dos mandatos, de 1995 a 2016 .57

Gráfico 12 - Taxa de disciplina da coalizão, por mandato, de 1995 a 2016. 60

Gráfico 13 - Taxa de disciplina da coalizão, por mandato, de 1995 a 2016. 61

Gráfico 14 - Número de deputados e taxa de disciplina da coalizão, por mandato, de 1995 a 2016. 
Gráfico 15 - Percentual de ministros sem filiação partidária, no início e no fim dos mandatos, de 1995 a 2016.

Gráfico 16 - Taxa de coalescência, por mandato, de 1995 a 2016

Gráfico 17 - Tempo médio de permanência dos ministros, por mandato, de 1995 a 2016

Gráfico 18 - Número efetivo de partidos políticos, por mandato, de 1995 a 2016 .70

Gráfico 19 - Número de partidos e de deputados de partidos com menos de 10 (dez) cadeiras na Câmara dos Deputados, por mandato, de 1995 a 2016.

\section{LISTA DE SIGLAS E ACRÔNIMOS}

\begin{tabular}{|c|l|}
\hline CEBRAP & Centro Brasileiro de Análise e Planejamento \\
\hline IPEA & Instituto de Pesquisa Econômica Aplicada \\
\hline FHC & Fernando Henrique Cardoso \\
\hline MP & Medida provisória \\
\hline PMDB & Partido do Movimento Democrático Brasileiro \\
\hline PSDB & Partido da Social Democracia Brasileira \\
\hline PT & Partido dos Trabalhadores \\
\hline
\end{tabular}




\section{SUMÁRIO}

1 INTRODUÇÃ

2 O PRESIDENCIALISMO DE COALIZÃO E SUAS INSTITUIÇÕES............... 17

3 AS ONDAS EXPLICATIVAS DO PRESIDENCIALISMO DE COALIZÃO ... 23

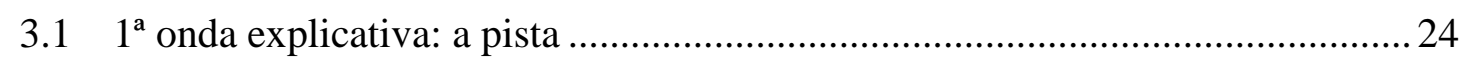

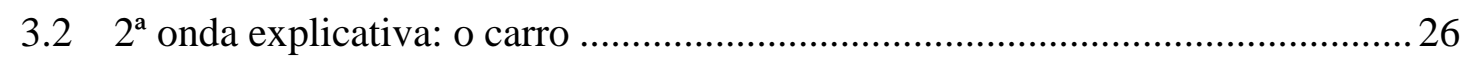

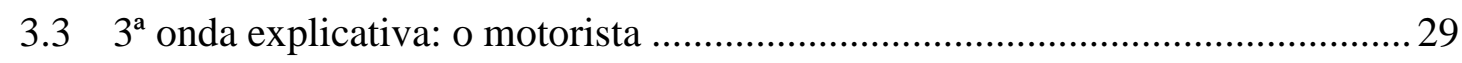

4 HEMOGRAMA DA GOVERNABILIDADE ......................................................... 40

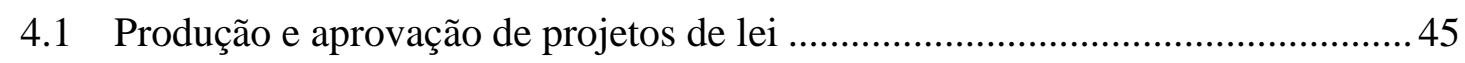

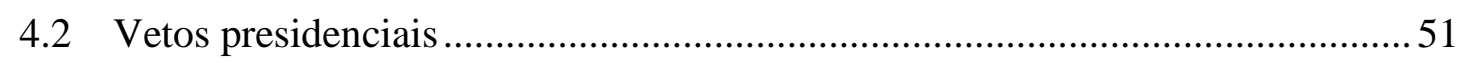

4.3 Aprovação de medidas provisórias .................................................................. 55

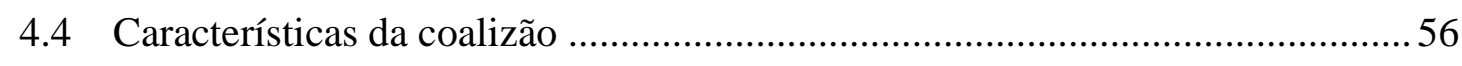

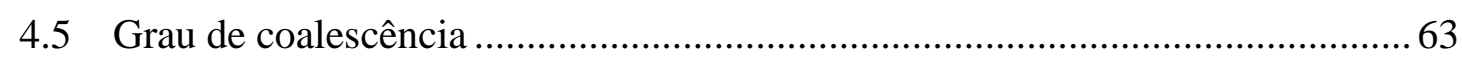

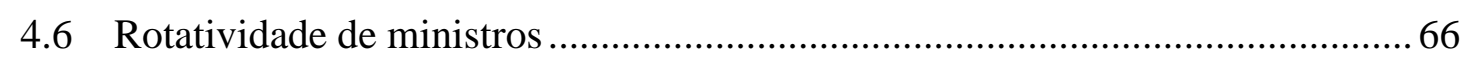

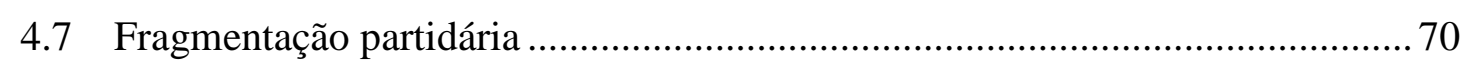

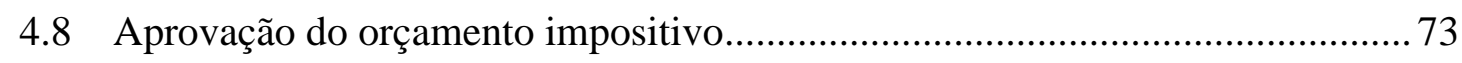

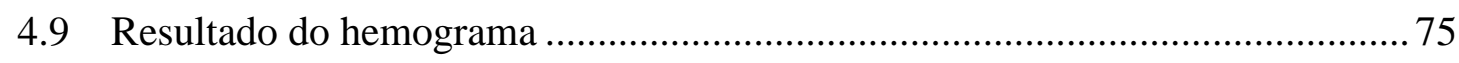

5 ESTILO DE GOVERNAR E GOVERNABILIDADE ...................................... 76

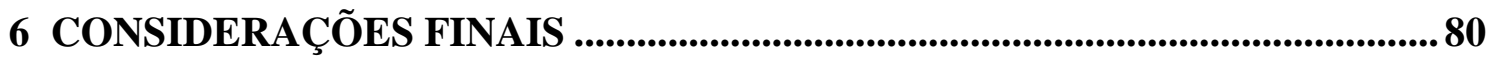

REFERÊNCIAS BIBLIOGRÁFICAS ...........................................................................8 84 


\section{INTRODUÇÃO}

O sistema político brasileiro, composto pela reunião de características presidencialistas, multipartidárias e representação proporcional, é chamado pela literatura de "presidencialismo de coalizão". Enquanto alguns cientistas políticos enxergam alto potencial desestabilizador dessa combinação institucional, outros defendem a existência de instrumentos capazes de equilibrar a relação entre os Poderes.

Nos últimos anos, notadamente a partir de 2014, há uma crise de governabilidade no Brasil, marcada especialmente pela deterioração da relação entre Executivo e Legislativo, em que aumentam, a cada dia, os custos de transação relacionados à condução governamental e à adoção de políticas públicas. Esse processo, inclusive, culminou com o impeachment de Dilma Rousseff e o estabelecimento de um "governo provisório", altamente frágil e instável. A agenda legislativa, por sua vez, tem sido tomada por pautas relacionadas à disputa política pura, pouco responsivas às demandas da sociedade.

As principais instituições do presidencialismo de coalizão brasileiro estão vigentes e consolidadas desde a Constituição de 1988, especialmente a partir de 1995. Ou seja: as regras do jogo são praticamente as mesmas desde então, o que levaria a crer que os processos políticos tenderiam a certa estabilidade. Em momentos anteriores, os conflitos entre Executivo e Legislativo parecem ter sido absorvidos pelo próprio sistema, evitando a paralisia. Recentemente, o equilíbrio foi interrompido, com o surgimento de uma crise político-institucional mais aguda e produtora de instabilidade. Desse modo, a explicação exclusivamente institucionalista - de que os resultados políticos decorrem das regras do jogo - parece não cobrir todo o fenômeno. Como e por quê isso ocorreu? Este trabalho parte, portanto, da premissa de que a crise política atual é reflexo da baixa governabilidade nos últimos anos, decorrente da falta de apoio parlamentar ao Executivo. Nesse sentido, a hipótese de pesquisa é que diferentes estilos de governar geram diferentes níveis de governabilidade.

Dadas a relevância e atualidade do fenômeno, os cientistas políticos brasileiros têm buscado explicações para a situação política atual. Amorim Neto $(2016)^{1}$, por exemplo, lança algumas hipóteses para sua compreensão, argumentando que o evento

${ }^{1}$ Conferência proferida no "Seminário Internacional 30 Anos de Presidencialismo de Coalizão: Balanço e Perspectivas de Reforma”, em 16 de junho de 2016, em Brasília-DF. 
pode ser explicado por dois tipos de circunstâncias que teriam conduzido à crise. Para ele, as "condições necessárias" seriam: i) a crise econômica internacional; ii) a rigidez orçamentária; e iii) a alta fragmentação partidária. Além delas, seriam “condições suficientes": i) a fragmentação e a heterogeneidade da coalizão; ii) o próprio sistema presidencialista; iii) a Operação Lava-Jato, que constrangeu a classe política; e iv) a personalidade política da presidenta. Segundo seu argumento, enquanto os cinco primeiros fatores são mais conhecidos e explorados pela literatura, os dois últimos são bem menos "triviais".

Sobre o assunto, Abranches (2014) desenvolve a tese dos ciclos do presidencialismo de coalizão. O primeiro seria o chamado "ciclo centrípeto", caracterizado pela "presidência com sinal fortemente positivo". Nele, o presidente goza de alta popularidade, o desempenho econômico é favorável, a inflação está sob controle, e a renda real é estável ou crescente. Neste contexto, o chefe do Executivo sequer precisa de muita habilidade ou empenho para negociar a adesão da coalizão a seu projeto de governo ou neutralizar as tentativas da oposição de abrir dissidências na coalizão. Tratase, portanto, de um ciclo de gestão da coalizão facilitada pelo ambiente e pelo alto poder de atração do presidente.

No "ciclo de ambivalência", por sua vez, o sinal positivo da presidência é fraco e com poucos sinais de apoio dos eleitores. A força centrípeta não tem mais capacidade de atração suficiente para evitar a dispersão de segmentos dos maiores parceiros da coalizão - às vezes até mesmo do partido presidencial -, e os efeitos da fragmentação partidária se fazem sentir mais fortemente. A rivalidade entre os parceiros passa a afetar o núcleo central do governo, que tem que conviver também com crises de corrupção. Na economia, o cenário é de estagnação, alta da inflação e queda da renda real. $\mathrm{O}$ autor situa o final do $1^{\mathrm{o}}$ mandato da Presidenta Dilma Rousseff nesse ciclo (ABRANCHES, 2014).

Por fim, no "ciclo centrífugo", a presidência passa a ter sinal negativo. A popularidade cai fortemente e a liderança presidencial é contestada, da mesma forma que o núcleo central do governo. Há paralisia decisória e legislativa, levando o sistema a uma crise de governança.

Também a respeito da crise, Araújo (2015) reúne dados sugestivos de que, no governo Dilma, a gestão da coalizão não considerou que a relação com o Congresso é mais complexa do que a simples distribuição de cargos, mas supõe a motivação dos atores partidários para implementar políticas. Nesse caso, a centralização do controle pelo 
núcleo duro teria prejudicado a articulação entre os dois Poderes e levado ao enfraquecimento da lealdade parlamentar em relação à presidente.

Neste trabalho, o período analisado será de 1995 a 2016, ou seja, os dois mandatos de FHC (Fernando Henrique Cardoso), Lula (Luis Inácio Lula da Silva) e Dilma (Dilma Vana Rousseff). Esse recorte temporal deve-se a três principais motivos. O primeiro decorre da teoria de Power (2009), segundo a qual o presidencialismo de coalizão mostrase verdadeiramente consolidado no Brasil a partir de 1995, quando a coordenação entre Executivo e Legislativo passou a ser mais efetiva, possibilitando aos presidentes a construção de supermaiorias no Congresso. A segunda razão é que, durante o período, foram formadas distintas coalizões no que se refere ao tamanho e ao espectro ideológico, e com grande variação da agenda de políticas públicas, o que viabiliza um amplo e rico escopo temporal para a análise. A terceira justificativa, de menor relevância, é que FHC foi o primeiro presidente eleito após a redemocratização que conseguiu concluir o mandato.

Desse modo, a questão central que se coloca aqui é: nos mandatos FHC, Lula e Dilma, quais os indicativos e as causas das mudanças no padrão de relacionamento com o Congresso, que refletiram na governabilidade e desencadearam a crise política?

Conforme será tratado adiante, a literatura trata o presidencialismo de coalizão basicamente sob duas abordagens. A primeira descreve o sistema político brasileiro como muito vulnerável, gerador de altos custos de governar e tendente à paralisia decisória, em virtude da combinação explosiva de suas instituições (Cf. ABRANCHES, 1988; AMES, 2001; ANASTASIA, 2004; PEREIRA; MULLER, 2002).

Outra parte dos autores, por sua vez, argumenta que o sistema possui ferramentas de coordenação entre o Executivo e parlamento, viabilizando a governabilidade. Dessa forma, os poderes presidenciais e as normas procedimentais seriam capazes de matizar o potencial desestabilizador da combinação de regras (Cf. FIGUEIREDO; LIMONGI, 1998. FIGUEIREDO, 2001; SANTOS, 2002; RENNÓ, 2006; PEREIRA; MELO, 2012).

No âmbito de cada uma dessas correntes, há tanto abordagens mais teóricas quanto estudos empíricos acerca da governabilidade e da dinâmica da relação entre os Poderes. Entre as pesquisas aplicadas - que mais dialogam com os propósitos deste trabalho -, há estudos i) que tratam do papel das instituições políticas como indutoras de 
comportamentos, e ii) outros mais diretamente relacionados à governabilidade. Ambos serão tratados a seguir, a começar pelos primeiros.

Ames (2001) analisa as estratégias de campanha dos candidatos à Câmara dos Deputados, a partir dos dados sobre as disputas pela reeleição em 1990 e as emendas orçamentárias dos congressistas. Na pesquisa, o autor conclui que as regras do sistema eleitoral induzem os parlamentares ao atendimento às suas clientelas eleitorais.

Em outro estudo, ele examina a motivação dos deputados brasileiros, a partir de dados sobre o conteúdo das votações na Assembleia Nacional Constituinte e o início do governo Collor. Ele constata o peso do fisiologismo nas duas ocasiões, fazendo com que os parlamentares mais beneficiados por programas e recursos votassem a favor do fortalecimento do Executivo (AMES, 2001).

Ao verificar também as votações realizadas entre 1991 e 1998, a partir de um “modelo de cooperação e deserção das maiorias partidárias”, Ames (2011) constata que os líderes têm baixa capacidade de indução de suas bancadas à cooperação e dependem do apoio dos parlamentares em cada questão específica.

Lemos (2001) reúne as 817 propostas legislativas nas áreas de educação e saúde apresentadas entre 1988 e 1994. A autora verifica que na atividade parlamentar são mais presentes os projetos de cunho mais geral e difuso do que aqueles voltados para públicos e regiões específicas, do tipo pork-barrel. Segundo ela, esse resultado está relacionado às instituições legislativas, à estrutura do Congresso e à segmentação da atividade parlamentar.

Ricci (2003), por sua vez, avalia as propostas aprovadas e rejeitadas pelo Congresso, bem como as vetadas pelo Executivo, de 1991 a 2002. No seu estudo, ele cria uma tipologia para os projetos de lei de acordo com o seu conteúdo, enquadrando-os nas categorias propostas, e verifica quais as deliberações do Congresso e do Executivo em relação a cada um. O autor conclui que as instituições eleitorais, sobretudo as regras proporcionais, somadas aos custos internos do processo legislativo, desestimulam os parlamentares a produzirem leis de caráter paroquial.

Lemos e Ricci (2011), a partir da análise de uma série de surveys aplicados a parlamentares por mais de vinte anos, identificam que a maior parte afirma que os próprios eleitores demandam comportamentos clientelistas, especialmente em relação à 
obtenção de emendas parlamentares. Analisando esse resultado sob a perspectiva institucional, tal percepção também tem relação com as instituições eleitorais.

Por outro lado, as pesquisas relacionadas mais diretamente à governabilidade recaem, em geral, sobre aspectos específicos do fenômeno, medindo o comportamento de determinado indicador considerado capaz de captar a capacidade de governar.

Limongi (2006), por exemplo, a partir de dados sobre a produção e aprovação de projetos de lei referentes ao período de 1988 a 2006, calcula as seguintes taxas:

- de participação: percentual de projetos de inciativa do Executivo sobre o total de projetos tramitados

- de dominância: percentual de projetos de iniciativa do Executivo aprovados em relação ao total de projetos aprovados;

- de sucesso: percentual de projetos de iniciativa do Executivo aprovados em relação ao total de projetos de inciativa do Executivo;

O autor também levanta a disciplina partidária da base do governo, isto é, a proporção de deputados da coalizão que votaram de acordo com a indicação expressa do líder do governo, de 1988 a 2006 (LIMONGI, 2006).

Freitas (2013), por sua vez, realiza a mensuração da disciplina partidária de 1989 a 2011, com foco na concordância dos partidos com o governo na Câmara e no Senado. Em seu estudo, ela conclui que existe forte coordenação entre as posições dos Poderes, e que os líderes têm papel central no processo.

Amorim Neto (2006), com o objetivo de medir a correspondência entre o peso no Congresso e a participação ministerial, calcula a taxa de coalescência a partir do mandato de Sarney. Santos (1986) mensura a fragmentação partidária entre 1946 e 1964, e calcula também as a taxa de aprovação de projetos de lei no período, concluindo que os piores resultados foram observados na véspera do golpe militar.

A medição empírica da governabilidade no Brasil é realizada pela literatura de maneira pontual, esparsa e desagregada. Além disso, alguns sinalizadores da capacidade de governar, ainda que tratados na teoria, são pouco explorados em termos quantitativos - com medição, consolidação de dados e cálculos. 
É o caso, por exemplo, dos vetos presidenciais - medidas extremas, que retratam o conflito não resolvido durante o processo legislativo, - e das medidas provisórias - cuja não votação, alteração, rejeição ou veto representam também dissenso entre os Poderes. Do mesmo modo, não são exploradas taxas como rotatividade de ministros, tamanho proporcional da coalizão, número de partidos com menos de dez cadeiras na Câmara, as quais farão parte da proposta metodológica que será apresentada neste trabalho.

Do mesmo modo, a aprovação do orçamento impositivo, que tornou obrigatória a execução das emendas individuais, foi mais abordada pela literatura em relação às suas potenciais consequências do que como fenômeno indicativo da fragilidade do governo. Antes de 2014, a efetividade das propostas parlamentares ao orçamento dependia da coordenação com o Executivo para a concretização do desembolso de recursos (Cf. LEMOS E RICCI, 2011). Com a mudança de regra, houve evidente alteração na correlação de forças entre os Poderes.

Este estudo pretende, portanto, analisar comparativamente o fenômeno da governabilidade durante os dois mandatos de FHC, Lula e Dilma, por meio de análises quantitativas. Para isso, serão utilizados indicadores i) recorrentes na literatura e ii) propostos no âmbito deste trabalho, com base no suporte teórico a ser oportunamente apresentado.

A pesquisa aqui desenvolvida faz uso de dados secundários de duas fontes: i) o sítio eletrônico da Presidência da República, que contém a relação de todos os atos normativos, por ano; ii) o Banco de Dados Legislativos do Centro Brasileiro de Análise e Planejamento (CEBRAP) ${ }^{2}$. No primeiro caso, as bases foram acessadas diretamente, e os tratamentos foram realizados manualmente para o posterior trabalho de cálculos e construções gráficas. No segundo, os dados foram tratados de duas formas: i) quanto a alguns indicadores, os dados brutos - como relação de partidos, parlamentares e coalizões, bem como listas de atos normativos, informações diversas sobre autoria, trâmite, votação e vetos - foram enviados pela equipe técnica do CEBRAP, em vários arquivos de Excel, e precisaram ser organizados, consolidados e trabalhados para a realização dos cálculos e elaboração dos gráficos e tabelas pretendidos; ii) quanto a outros

\footnotetext{
${ }^{2}$ Agradecimento à Joyce Luz, do CEBRAP, que disponibilizou os dados e gentilmente esclareceu várias questões.
} 
indicadores, os cálculos puderam ser realizados por meio de software do próprio CEBRAP, a partir da utilização de filtros específicos.

O tratamento e a análise dos dados permitirão o desenvolvimento de uma metodologia que consiste na principal contribuição empírica deste trabalho. Esse instrumental, além de ter gerado os achados desta pesquisa, é apresentado como proposta de ferramenta para medir e comparar as condições de governar em quaisquer governos, a partir de indicadores utilizados com diferentes intensidades, ou mesmo não explorados, pela literatura.

Nesse sentido, o tratamento dos dados empíricos dá origem ao que será oportunamente denominado "hemograma da governabilidade", uma proposta de método para a exploração do fenômeno da crise, que contempla, basicamente, dimensões ligadas às propostas legislativas, às características da coalizão, à dinâmica da composição ministerial e à fragmentação partidária. Os sinalizadores da governabilidade serão indicadores ligados ao sucesso das propostas normativas, à estabilidade ministerial, à disciplina e satisfação da base e à multiplicidade de partidos. Os resultados obtidos por meio dessa análise indicarão o nível de dificuldade observado em cada mandato na relação entre Executivo e Legislativo e, portanto, as diferentes capacidades de governar.

Nessa perspectiva, o estudo aqui desenvolvido parte da premissa de que ocorreu, sim, um processo de abalo da relação entre Executivo e Legislativo, em que a base parlamentar de apoio tornou-se cada vez mais desgovernada. O trabalho desenvolve-se, portanto, a partir desse pressuposto. Seu objetivo principal é mapear os indicativos da saúde do presidencialismo de coalizão, que diagnosticam os sinais da crise política, e problematizar as explicações exclusivamente institucionalistas. Como objetivos específicos e contribuições secundárias ao debate acerca do sistema político brasileiro, a pesquisa irá:

i) comprovar o processo de redução da governabilidade nos últimos anos, por meio de dados quantitativos;

ii) desenvolver ferramenta metodológica - "hemograma" - capaz de medir a governabilidade no tempo e identificar sinais de crise;

iii) apresentar a sistematização analítica da literatura sobre o presidencialismo de coalizão em ondas explicativas; 
iv) propor maior exploração de fatores não institucionalistas como explicação para o fenômeno da crise, incluindo-os como uma terceira onda explicativa.

Para isso, o estudo está organizado em cinco seções, considerando esta introdução. Na próxima (segunda), são apresentadas as bases teóricas do presidencialismo de coalizão e suas instituições. A terceira aborda o que se propõe chamar de "ondas explicativas" sobre o sistema político brasileiro. Na quarta seção, é explorada a premissa acerca da interrupção do equilíbrio nos últimos anos. Para isso, realiza-se um teste diagnóstico do estado de saúde do presidencialismo de coalizão - o "hemograma da governabilidade" , composto por 8 (oito) dimensões e 13 (treze) indicadores resultantes da consolidação, cruzamento e análise de diferentes dados relativos ao período de 1995 a 2016 . A quinta seção traz a discussão sobre o perfil do núcleo duro dos governos e sua possível relação com a governabilidade. Na última, são tecidas as considerações finais. 


\section{O PRESIDENCIALISMO DE COALIZÃO E SUAS INSTITUIÇÕES}

Há autores que acreditam que o sistema presidencialista, por si só, explicaria parcialmente a instabilidade da democracia em alguns países da América Latina (CHEIBUB e PRZEWORSKI, 2004). Outros, contudo, agregam novos elementos à análise, argumentando que o problema, especialmente no caso do Brasil, residiria na combinação explosiva entre presidencialismo, federalismo, bicameralismo, multipartidarismo e representação proporcional (ANASTASIA, 2004).

Se por um lado a reunião desses elementos expressa as heterogeneidades sociais, econômicas, políticas e culturais do Brasil - marcadas por desigualdades, conflitos de interesses, fracionamento partidário, propensão à formação de amplas coalizões, forte tradição presidencialista e proporcional -, a coexistência dessas instituições é entendida por grande parte da literatura como geradora de efeitos desestabilizadores. O dilema institucional brasileiro, portanto, seria o de encontrar soluções institucionais que promovessem a governabilidade (ABRANCHES, 1988; MAINWARING, 1997; POWER, 2009; SANTOS, 2003).

Abranches (1988), de forma pioneira, chama esse traço do sistema político brasileiro de "presidencialismo de coalizão", em contraposição ao presidencialismo de gabinete, caracterizado pelo controle parlamentar sobre o Executivo. $\mathrm{O}$ autor é um dos primeiros a identificar que o presidencialismo pode funcionar como o parlamentarismo, no qual os presidentes minoritários comportam-se como primeiros ministros de sistemas multipartidários europeus, vendo-se obrigados a costurar maiorias no Congresso por meio da aproximação com partidos que não são os seus (POWER, 2009, p. 133).

Contrariando o que afirma parte da literatura, Power (2011) parte de um estudo de Cheibub, Przeworski e Saiegh (2002) para argumentar que o presidencialismo de coalizão não é uma exclusividade brasileira. Segundo a pesquisa, governos de coalizão existem em $78 \%$ dos países parlamentaristas e $66 \%$ das nações presidencialistas. De todo modo, o Brasil é o país na América Latina onde os presidentes mais dependem de coalizões para garantir uma maioria parlamentar (POWER, 2009, p.135).

O processo de construção dessas coalizões, segundo Abranches (1988), envolveria três momentos: i) a formação da aliança eleitoral, em torno de diretrizes programáticas e princípios; ii) a composição do governo, marcada por disputa por cargos; e iii) a transformação da aliança em coalizão governante, quando surgem os conflitos de agenda. 
O caminho crítico para a consolidação da coalizão estaria, pois, entre o segundo e o terceiro momento, em que o Executivo tem que fazer uso de recursos de poder que detém, para garantir a governabilidade e evitar a inoperância.

Em sistemas multipartidários, caracterizados pelo fracionamento, a permanente construção de acordos que compatibilizem as divergências é um exercício fundamental para a estabilidade da coalizão. Nesse sentido, os apoios para aprovação de matérias no Congresso são mantidos sobretudo por meio de liberação de emendas parlamentares e provimento de cargos. Com a ocupação dos Ministérios por quadros de outros partidos, aumentam os custos de transação para negociações referentes a políticas públicas de interesse do governo, tornando mais complexa a coordenação horizontal.

Para Ames (2001), as crises de governabilidade no Brasil resultam da grande quantidade de veto-players. Isso decorre do conjunto de instituições disfuncionais, particularmente as regras eleitorais - a representação proporcional em lista aberta, a existência de grandes distritos a as baixas barreiras à entrada de partidos.

Segundo ele, as prerrogativas constitucionais dos presidentes brasileiros são insuficientes para neutralizar sua condição de refém das demandas fisiológicas e clientelistas dos parlamentares. Para o andamento de sua agenda, o Executivo tem que atuar em permanente distribuição de cargos, programas, obras e recursos, sendo necessárias constantes alterações táticas nesses incentivos no decorrer de sua administração. O presidente ainda tem que lidar com os interesses dos ministros, que podem ter prioridades políticas distintas das suas (AMES, 2001).

Ricci (2003) também reconhece a importância das instituições políticas para a indução do comportamento parlamentar, mas argumenta que elas desestimulam a prdução de projetos de lei do tipo pork-barrel. No seu estudo, o autor parte da análise das propostas do Legsilativo produzidas de 1991 a 2002.

Segundo ele, há altos custos procedimentiais, o que reduz os incentivos para estratégias paroquiais. Para o autor, os incentivos eleitorais levam os congressitas a concentrarem seus esforços na produção de uma legislação de caráter mais geral. Isso teria relação com o somatório de dois fatores principais: i) o arranjo institucional, que combina representação proporcional em distritos médios-grandes com população numerosa; e ii) os custos de transação intrínsecos aos trabalhos legislativos (RICCI, 2003). 
Na mesma linha, por meio da análise de projetos de lei relacionados às áreas de saúde e educação apresentados entre 1988 e 1994, Lemos (2001) observa que os parlamentares não concentram os benefícios em indivíduos, grupos ou localidades específicas. Ao contrário, as regras e procedimentos, bem como a estrutura do Congresso e a segmentação da atividade parlamentar, desestimulariam o comportamento paroquial do Legislativo.

De acordo com outros autores, essa junção de sistema proporcional, presidencialismo e o multipardirarismo pode não levar o sistema à paralisia, se consideradas as variáveis internas do processo decisório. No estudo de Figueiredo e Limongi (1998), por exemplo, os dados demonstram preponderância do Executivo sobre o Congresso que, por sua vez, atua de forma cooperativa e vota com disciplina. Isso seria decorrente dos mecanismos trazidos pela Constituição de 1988, como a ampliação dos poderes legislativos do Presidente e das ferramentas legislativas à disposição dos líderes dos partidos, que podem neutralizar as estratégias individualistas dos parlamentares.

Para Pereira e Melo (2012), se os partidos e presidentes não conseguissem construir maiorias capazes de governar, os sistemas presidenciais latino-americanos deveriam ter fracassado e gerado baixa governabilidade. De acordo com os autores, ao contrário do que sugeria a literatura da década de 1990, o presidencialismo de coalizão sustentou uma democracia forte e um governo estável no Brasil.

Segundo essa corrente, portanto, o Executivo teria poder de agenda, dominando o processo legislativo, o qual é organizado de forma muito centralizada e submetido a regras procedimentais que reproduzem princípios partidários. Logo, o presidente possuiria meios para induzir os parlamentares à cooperação, compelindo os congressistas a votarem de forma disciplinada para obtenção de recursos, como cotas de patronagem, influência política e retornos eleitorais. Para Santos (2003), essa concentração de poderes nas mãos do Executivo e de lideranças partidárias pode ser entendida como fruto da inércia institucional, ou da natureza path dependence da evolução institucional, por ser um traço do regime autoritário que se manteve mesmo após o período de transição democrática pelo qual o país passou na década de 1980 .

Especialmente a partir de 1995, o presidencialismo de coalizão tem se demonstrado uma instituição - ou um conjunto de instituições - consolidada, tendo sido incorporada ao sistema político e com tendência a se manter sem alterações significativas. 
Power, em trabalho publicado em 2011 - ainda sem ter condições de avaliar, portanto, o mandato Dilma - lança algumas hipóteses explicativas para tal fenômeno, sugerindo que isso poderia ser fruto, por exemplo: i) da liderança de Lula e de FHC, ii) da estabilização pós-1994, que criou melhores condições para apoio legislativo aos presidentes, iii) de fatores globais, regionais e nacionais que atenuaram a polarização política no Brasil ao longo do tempo, ou iv) do processo cumulativo de aprendizado político - democracy by trial and error. $\mathrm{O}$ autor diz acreditar que se trata de um somatório de fatores, mas aposta mais fortemente na última hipótese (POWER, 2011, p. 158-159). Para Freitas (2013), hoje estaria pacificado que o Brasil é governável. O presidente aprova a maioria das propostas que envia ao Legislativo, o que é demonstrado por "altas taxas de sucesso", e a maioria das leis decorre de projetos de iniciativa do Executivo, comprovado por "altas taxas de dominância" (FIGUEIREDO e LIMONGI, 1999).

A partir de uma pesquisa aplicada em 2009 aos deputados e senadores, Power (2009) conclui que os parlamentares reconhecem os problemas do presidencialismo de coalizão, como o estímulo à corrupção e ao clientelismo, a infidelidade partidária, a lentidão nas decisões e distorção dos resultados das urnas, visto que o eleitor não consegue antecipar o perfil do futuro governo. No saldo final, todavia, os congressistas são amplamente favoráveis ao sistema, acreditando que ele promove uma democracia de consenso, com representação de diversos interesses sociais, com moderação da polarização ideológica e se assemelhando ao parlamentarismo na prática. O julgamento parece ser que o presidencialismo de coalizão é falho, mas funciona.

Esse tipo de análise, que considera as regras do jogo como fatores que moldam comportamentos e influenciam os resultados, integra a abordagem denominada (neo)institucionalista. Essa escola surgiu em meados dos anos 1980 como reação às perspectivas behavioristas, focadas nos atores, para elucidar o papel desempenhado pelas instituições nos processos sociais e políticos. Trata-se de resposta a uma ênfase exagerada na agência sem estrutura - ou seja, a metodologia clássica da escolha racional - ou na agência sem agentes conscientes ou estruturas - ou seja, o comportamentalismo (SCHIMIDT, 2008, p. 313).

A perspectiva neoinstitucional possuiu três principais correntes - a da escolha racional, a histórica e a sociológica. De acordo com a primeira abordagem, a explicação sobre a origem das instituições estaria, sobretudo, nas funções exercidas por elas e nas 
vantagens que elas propiciam (HALL e TAYLOR, 1996, p. 205-206). A preocupação central, portanto, não é com os atores, mas com as regras, a partir do pressuposto de que a ação individual é uma adaptação ótima ao ambiente institucional e a própria interação entre os indivíduos é uma resposta otimizada à relação recíproca entre ambos - atores e instituições (TSEBELIS, 1998, p. 51).

Para o institucionalismo da escolha racional, cada instituição possui uma ou várias funções. A existência da instituição é explicada, pois, a partir do valor assumido por essas funções aos olhos dos atores influenciados pela instituição, e os indivíduos criam a instituição de modo a realizar esse valor. Se a instituição está submetida a algum processo de competição, ela deve sua sobrevivência ao fato de oferecer mais benefícios aos atores interessados do que as formas institucionais concorrentes (HALL; TAYLOR, 1996, p. 205-206).

As instituições podem também ser explicadas como resultados de escolhas feitas em momentos anteriores e que determinaram os processos subsequentes, dificultando o retorno às condições pretéritas ou a mudança de rota. De acordo com essa corrente, denominada neoinstitucionalismo histórico, condições antecedentes definem uma série de opções disponíveis para atores durante um ponto-chave de escolha. A seleção efetuada durante um momento crítico é consequencial, pois leva à criação de padrões institucionais ou estruturais que perduram ao longo do tempo (HAL; TAYLOR, 1996; MAHONEY, 2002, p. 4-6).

Por fim, o neoinstitucionalismo sociológico parte da premissa de que muitas medidas e procedimentos organizacionais não são adotados por serem eficientes, mas por representarem práticas culturais, tal como mitos e cerimônias que fazem parte das sociedades. Nessa perspectiva, as instituições não são somente as regras e procedimentos formais, mas também os sistemas de símbolos, os esquemas cognitivos e os modelos morais que fornecem "padrões de significação" que guiam a ação humana. (HALL; TAYLOR, 1996, p. 207, 208).

Assim, para o (neo) institucionalismo mais puro, o que importa são as características que decorrem da estrutura institucional, e não das qualidades pessoais de determinado líder (LIMONGI e FIGUEIREDO, 2006). O foco de todas as correntes neoinstuticionalistas reside, pois, na criação, permanência e alteração das instituições. São os atores, no entanto, que as adotam, as definem e operam sob seu regramento. Ainda 
que determinado arcabouço institucional constranja ou estimule os comportamentos, a estrutura das instituições seria suficiente para explicar os resultados políticos, especialmente as situações de crise?

Além disso, a supervalorização das instituições formais também parece insatisfatória para a compreensão dos outputs políticos. Ignorar as instituições informais, que vão desde as burocráticas e legislativas ao clientelismo e patrimonialismo, implica o risco de perder a visão de muitos dos incentivos e restrições reais que fundamentam o comportamento político (HELMKE; STEVEN LEVITSKY, 2003).

Nessa perspectiva, a partir do suporte teórico brevemente apresentado acima, este trabalho irá dialogar com os postulados institucionalistas, por meio da análise da governabilidade no período de 1995 e 2016 e da proposição de hipóteses explicativas para a recente crise. 


\section{AS ONDAS EXPLICATIVAS DO PRESIDENCIALISMO DE COALIZÃO}

Após a publicação do texto seminal de Abranches, em 1988, a literatura tem analisado os pressupostos e conclusões do autor acerca do presidencialismo de coalizão. Para boa parte dos autores, o modelo político brasileiro tem sido capaz de promover, com algumas oscilações, a fluidez nas relações Executivo-Congresso e a governabilidade. Mesmo em momentos críticos, as instituições e os instrumentos inerentes ao sistema têm respondido, promovendo o restabelecimento dos canais de comunicação política e de definição e implementação das políticas públicas (MARTINS, 2016).

Como avaliar, então, essa suposta interrupção de equilíbrio no bojo do sistema brasileiro, à luz das teorias e estudos desenvolvidos pela literatura? A reflexão que será proposta aqui organiza o debate teórico como se fosse formado por camadas ou ondas explicativas, que não se opõem, mas vão se acumulando e agregando novos elementos à compreensão do presidencialismo de coalizão brasileiro.

$\mathrm{Na}$ tentativa de tornar mais clara essa análise, serão adotadas metáforas ${ }^{3}$ para a abordagem das explicações teóricas relacionadas ao tema. A elaboração analítica, que será apresentada no tópico seguinte, pode ser sintetizada da seguinte forma:

Tabela 1 - Ondas explicativas do presidencialismo de coalizão

\begin{tabular}{|c|l|c|}
\hline $\begin{array}{c}\text { Onda } \\
\text { explicativa }\end{array}$ & \multicolumn{1}{c|}{ Descrição } & Metáfora \\
\hline \multirow{2}{*}{$1^{\text {a }}$} & $\begin{array}{l}\text { A base institucional do presidencialismo de coalizão, formada pela } \\
\text { combinação entre presidencialismo, multipartidarismo e representação } \\
\text { proporcional, tende a levar o sistema à ingovernabilidade. }\end{array}$ & Pista \\
\hline $2^{\text {a }}$ & $\begin{array}{l}\text { O próprio sistema político possui instrumentos que promovem a } \\
\text { coordenação entre Executivo e Parlamento, de modo a evitar a }\end{array}$ & Carro \\
\hline $3^{\text {a }}$ & $\begin{array}{l}\text { A construção de condições para a governabilidade depende também do } \\
\text { estilo de governar do núcleo duro do governo. }\end{array}$ & Motorista \\
\hline
\end{tabular}

Fonte: Elaboração própria

\footnotetext{
${ }^{3}$ Agradecimento especial ao Professor Rafael Silveira, pela valiosa sugestão das metáforas.
} 


\section{1 $1^{\text {a }}$ onda explicativa: a pista}

Independentemente da espécie, o gênero neoinstitucionalista é o pano de fundo de todas as análises que consideram que os resultados políticos têm relação com as instituições, e essa abordagem é o ponto de partida analítico para a onda explicativa aqui tratada, que tem como marco teórico a publicação seminal de Abranches, em 1988, autor do termo "presidencialismo de coalizão".

Essa onda será considerada como uma primeira camada de análise teórica acerca do sistema político brasileiro, que enxerga como explosiva a combinação entre as suas instituições, levando a alto risco de instabilidade e paralisia decisória. Por dizer respeito à base institucional do modelo, sugere-se aqui que essa abordagem seja vista como o piso de sustentação do presidencialismo de coalizão, formado por suas instituições, que precisa ser percorrido para a geração de resultados políticos, como uma pista.

No presidencialismo de coalizão, a fragmentação partidária leva o Executivo a ter que adotar um conjunto de práticas para conseguir governar. Ele precisa costurar uma ampla maioria, muitas vezes até oposta ideológica e programaticamente e composta por forças políticas muito distintas, às vezes adversárias. O "dilema institucional” brasileiro, portanto, faz do Presidente um permanente refém do Congresso, embora eleito diretamente, ao contrário do que ocorre no parlamentarismo (ABRANCHES, 1988).

Abranches (1988) descreve o sistema político brasileiro como sendo caracterizado pela instabilidade, pelo alto risco de paralisia decisória e pelo permanente perigo de ruptura da ordem política. Nesse sentido, o Executivo possui baixa liberdade para recomposição de forças por meio de reforma ministerial, sem que se ameacem as bases de sustentação. A coalizão, por sua vez, é inconstante e frágil, tornando permanente o perigo da formação de coalizões de veto no parlamento, o que conduz à paralisia decisória e à ruptura da ordem política. É possível compreender a tese de Abranches, portanto, como uma primeira onda explicativa sobre o presidencialismo de coalizão.

$\mathrm{Na}$ mesma linha, Mainwaring (1997) reconhece a difícil combinação das instituições políticas brasileiras - presidencialismo, sistema multipartidário fragmentado e partidos indisciplinados -, defendendo que essa junção não é compensada por prerrogativas institucionais do presidente, levando à necessidade de manutenção de uma base de apoio no Congresso. Para enfrentar o risco de formação de governos minoritários, 
como o partido do presidente dificilmente obtém a maioria no parlamento, ele precisa do apoio de outros partidos para evitar a paralisia decisória, que culminaria no "imobilismo político". A paralisia decisória decorreria, portanto, de processos de intensificação e dispersão de preferências e de fragmentação dos recursos políticos, o que estimula a formação de coalizões de veto ad hoc e dificulta a formação de maiorias governativas estáveis, levando ao impasse permanente (SANTOS, 1986).

De acordo com estudo de Cheibub e Przeworski (2004), o presidencialismo por si só já é um sistema muito vulnerável, independentemente de os governos serem ou não de coalizão. Segundo Pereira e Mueller (2002), o Brasil padece de quase todas as patologias institucionais reconhecidas pela literatura como responsáveis pelo custo de governar. Para Power (2000), a combinação de presidencialismo com sistema proporcional de lista aberta dirigiu o sistema rumo ao personalismo, coalizões ad hoc, clientelismo e paroquialismo.

Em seu estudo sobre a governabilidade no Brasil, Ames (2012) atribui às instituições eleitorais a fragilidade do sistema político. Para ele, a representação proporcional em lista aberta o enfraquecimento dos partidos e dos líderes partidários, visto que os eleitores escolhem candidatos individuais e as lideranças não têm controle sobre as listas.

Na sua visão, os líderes partidários não conseguem controlar suas bancadas, e os congressistas acabam por "vender" sua cooperação pelo preço e forma que mais lhes convêm. O presidente, por sua vez, precisa permanente reconstruir maiorias, tendo que fazer uso de contrapartidas clientelistas e fisiológicas em troca de apoio parlamentar.

Isso gera um sistema travado, que eleva o custo do processo decisório e a qualidade das decisões, que exige do Executivo benesses fisiológicas para o andamento dos seus projetos e a alteração do status quo (AMES, 2012).

A literatura aqui apresentada aborda o presidencialismo de coalizão como resultante de um conjunto de instituições que, combinadas, oferecem alto risco à estabilidade e à governabilidade. Neste trabalho, para representar essa abordagem teórica, propõe-se, conforme já dito, que o sistema político brasileiro seja visualizado como uma pista, com todas as curvas, obstáculos e buracos que precisam ser transpostos para que o governo funcione. 


\section{2 $2^{\text {a }}$ onda explicativa: o carro}

Como uma segunda onda explicativa, sucedendo a tese da ingovernabilidade e da paralisia decisória decorrentes da combinação entre as instituições políticas brasileiras, há autores que defendem que o sistema possui instrumentos que promovem a coordenação da ação entre o Executivo e o Legislativo, de modo a evitar o imobilismo institucional e viabilizar a condução do governo (FIGUEIREDO; LIMONGI, 1998; FIGUEIREDO, 2001; SANTOS, 2002; RENNÓ, 2006; PEREIRA; MELO, 2012). Neste trabalho, esse tipo de análise será considerado a segunda onda explicativa, entendida metaforicamente como o carro que trafega pela base institucional do sistema político - a pista - superando seus buracos, curvas e obstáculos.

Segundo Moisés (2011), as publicações mais recentes consideram superados os receios levantados no período de transição democrática, quando inclusive foi cunhada a expressão "presidencialismo de coalizão". Não se verificaram paralisia decisória ou relações conflituosas entre Executivo e Legislativo, tampouco instabilidade política. O autor afirma que a literatura reconhece o comportamento parlamentar disciplinado, de acordo com as orientações das coalizões transmitidas pelas lideranças do governo e partidárias. Desse modo, o sistema político tem garantido a aprovação dos projetos do Executivo, bem como o predomínio deste na formação da agenda legislativa.

Figueiredo e Limongi (1998), em trabalho que discute as bases institucionais do presidencialismo de coalizão, afirmam que não se comprovam os argumentos usualmente apresentados para questionar os governos de coalizão no presidencialismo. Analisando depoimentos de parlamentares e as políticas implementadas, ressaltam que o Congresso não tem sido obstáculo intransponível à implementação da agenda do Executivo.

Em outros estudos sobre a dinâmica da relação entre os poderes, Limongi e Figueiredo (1994, 1995 e 1996) concluíram que, fazendo uso de instrumentos institucionais disponíveis, os presidentes não negociam individualmente com parlamentares, mas com partidos e maiorias. O governo possui, portanto, diversas ferramentas de intervenção nos trabalhos legislativos, e os líderes partidários capazes de disciplinar o comportamento de seus membros em plenário. Logo, a atuação na arena legislativa é previsível e consistente (FIGUEIREDO; LIMONGI, 1998; SANTOS, 2003). 
Também segundo os autores, a Constituição de 1988 dotou os presidentes e líderes partidários de instrumentos eficazes de controle da agenda parlamentar, permitindo superar problemas de ação coletiva e negociação inerente ao legislativo brasileiro fragmentado. O Executivo passou a ter as novas prerrogativas, como iniciativa exclusiva para projetos orçamentários e fiscais, apresentação de emendas constitucionais, edição de medidas provisórias e pedidos de urgência na tramitação de projetos de lei. As novas regras da Câmara dos Deputados, aprovadas logo após a promulgação da Constituição de 1988, conferiram direitos aos líderes dos partidos em relação aos deputados considerados individualmente. As lideranças passaram a ter as prerrogativas de determinar a agenda do plenário, representar todos os membros do seu partido no Legislativo, restringir alterações e votações separadamente e nomear e substituir membros de comissões (FIGUEIREDO; LIMONGI, 2007).

Pereira e Melo (2012) também contestam a ideia de que a junção entre presidencialismo e multipartidarismo seria capaz de levar o sistema político à paralisia e a democracia à ruptura. Ao contrário do que alegam os críticos, os autores argumentam que tal arranjo institucional teria funcionado bastante bem, como seria o caso do Brasil, Chile e Uruguai.

Para eles, a chave para a funcionalidade no sistema estaria em três fatores. Em primeiro lugar, na força do presidente, que significa um Executivo constitucionalmente poderoso com a capacidade de ser pró-ativo e reativo, ou seja, mudar o status e evitar iniciativas indesejáveis da oposição (PEREIRA; MELO, 2012).

Além disso, a estabilidade do sistema também estaria ancorada nos bens de troca institucionalizados - "meios de pagamento" - para garantir a cooperação da coalizão e seu apoio no Congresso, como matização à fragmentação partidária. Isso se dá, por exemplo, por meio de postos de gabinete, nomeações para outros cargos, práticas clientelistas, direcionamento de investimentos e gastos públicos (PEREIRA; MELO, 2012).

Em terceiro lugar, estaria o sistema de controle das ações do Executivo, que são mecanismos de exigência de prestação de contas do governo. Aí estariam, primeiramente, os instrumentos de controle parlamentar, resultantes da competição política e da fragmentação do poder, mas incluem também o Judiciário, os tribunais de contas e a imprensa livre (PEREIRA E MELO, 2012). 
Eles também argumentam que, com a exceção de Collor, todos os presidentes brasileiros conseguiram construir maiorias no Congresso, por meio de dinâmica de cooperação e trocas. Logo, os autores defendem que a fragmentação partidária, além de não ter impedido o bom funcionamento do sistema e a estabilidade democrática, representou fator chave para alcançar a eficiência a partir dos compromissos estabelecidos entre as partes (PEREIRA; MELO, 2012).

Na mesma linha, Santos e Vilarouca (2008) defendem que o sistema político brasileiro não precisa de reformas radicais, pois há instrumentos à disposição dos presidentes e líderes partidários que evitam a fragmentação partidária e os incentivos paroquiais que decorrem das arenas eleitorais. Esses mecanismos referem-se à centralização do processo decisório nas mãos do presidente e dos líderes partidários que se concretizam por meio distribuição de ministérios e do controle de agenda pelo executivo mediante a edição de medidas provisórias e de decretos sobre administração e orçamento e o envio de requerimentos de urgência.

Para esses autores, portanto, os parlamentares não agem "cada um por si”, mas de maneira coordenada e previsível. Desse modo, o processo legislativo dentro do congresso é centralizado, pois o próprio sistema provê mecanismos que garantem a governabilidade, enfrentando o potencial tóxico das instituições de conformam o presidencialismo de coalizão (SANTOS; VILAROUCA, 2008).

Ao analisar a disciplina da base nas votações, Amorim Neto (2000) conclui que ela é bastante expressiva quando a composição dos gabinetes presidenciais é proporcional ao peso partidos no Congresso. Segundo ele, o comportamento legislativo, nesse caso, é tão disciplinado quanto àquele observado em sistemas parlamentaristas.

Pereira e Mueller (2002) ${ }^{4}$, em estudo sobre as relações entre o Executivo e o Legislativo no processo orçamentário, afirmam que as emendas parlamentares são importantes instrumentos de promoção da governabilidade. Segundo eles, embora essas verbas representem baixos valores em relação à totalidade do orçamento, são suficientes para promover o êxito eleitoral e a sobrevivência política dos deputados que integram a coalizão. Trata-se, portanto, de um custo baixo para que o Executivo obtenha alto grau de governabilidade sob o presidencialismo de coalizão. Os autores concluem que os

\footnotetext{
${ }^{44}$ Agradecimento ao professor Ricardo Martins, que apresentou interessante revisão de literatura em conferência proferida no "Seminário Internacional 30 Anos de Presidencialismo de Coalizão: Balanço e Perspectivas de Reforma", em 16 de junho de 2016, em Brasília-DF.
} 
mecanismos institucionais que conferem ao Executivo elevado controle sobre orçamento contrabalanceia os possíveis efeitos desestabilizadores decorrentes do sistema eleitoral, partidário e federativo.

Ao comparar o comportamento da coalizão no período 1946-64 e no pós-88, Santos (2002) verifica alta disciplina tanto da base governista quanto do campo oposicionista após a redemocratização. O mesmo autor, em trabalho intitulado "Defesa do Presidencialismo de Coalizão", argumenta que o modelo político brasileiro, embora complexo e de difícil manejo, é altamente democrático, maximizando simultaneamente a accountability e a representatividade.

Amorim Neto, Cox e MacCubbins (2003), analisando o período de 1989 a 1998, concluem que o governo FHC destaca-se por apresentar consistência entre composição partidária do gabinete, estratégia de iniciativa legislativa e forte cartel na definição da agenda legislativa, formando um governo realmente majoritário, agindo o Presidente como um Premier.

Em discussão sobre o papel do Poder Legislativo no presidencialismo de coalizão, nos governos FHC e Lula, Freitas (2013) afirma ser ponto pacífico que o Brasil é governável. No seu estudo, a autora conclui que Executivo e Congresso não têm agendas concorrentes ou conflitos irreconciliáveis. Para ela, a coalizão governa de fato, sendo responsável pela alteração ou manutenção do status quo, e os partidos políticos desempenham importante papel de coordenação nos processos de tomada de decisão.

Em linhas gerais, a argumentação de todos esses autores é no sentido de que o presidencialismo de coalizão não conduz à ingovernabilidade e à paralisia decisória, embora possa conter características institucionais que teoricamente poderiam levar o sistema ao colapso. Isso porque, segundo eles, existem ferramentas e outras instituições - o carro - que permitem a coordenação da relação entre o Executivo e o Legislativo, viabilizando a condução do governo. 


\section{3 $3^{\text {a }}$ onda explicativa: o motorista}

A terceira onda explicativa aqui proposta considera que o perfil dos atores importa no presidencialismo de coalizão. Ou seja: a pista traz o conjunto de instituições fundantes, o carro consiste nas ferramentas para transitar pela via, e o motorista maneja esses instrumentos.

Nessa linha, Neusdat (1990) argumenta que, à medida que a complexidade institucional dos gabinetes foi crescendo nos últimos anos, a capacidade do Presidente como gestor da burocracia decisória passou a ser determinante para o desempenho da presidência. A literatura sobre gestão presidencial o atribui, pelo menos parcialmente, ao perfil do próprio presidente. Para Lassance (2015), em sistemas presidencialistas, os presidentes são os principais responsáveis por criar expectativas, sinalizar oportunidades e implementar políticas de desenvolvimento. Os padrões de governança diferem muito de um para o outro e guardam consonância com seu perfil gerencial, seu grau de ativismo unilateral e seu manejamento de incentivos e restrições.

Barber (1972), um dos precursores das teorias sobre o perfil dos presidentes, propõe uma classificação que considera a personalidade presidencial em termos de três componentes principais: i) o caráter; ii) a visão de mundo; e iii) o estilo.

O estilo seria a parte mais visível da personalidade de um líder, pois consiste na forma habitual de realizar três papéis políticos: a retórica (palavras), as relações pessoais (pessoas) e o negócio/tarefas (trabalho). A "visão de mundo", por sua vez, diz respeito às crenças políticas, às convicções filosóficas e ideológicas fundamentais que moldam o comportamento. Para Barber (1972), no entanto, o núcleo da personalidade encontra-se no "caráter", que ele define como a forma pela qual o Presidente orienta-se para a vida não para o momento presente, mas duradouramente.

Com base nisso, Barber (1972) cria uma tipologia e cataloga a personalidade de todos os presidentes americanos até o mandato de Bush I, com base em duas métricas: i) como o presidente executa o seu papel político - se ativa ou passivamente e ii) se o presidente gosta ou não gosta das atividades que o seu papel exige - se positivo ou negativo. Combinando as duas dimensões, o autor obtém quatro tipos de caráter: o ativopositivo, o ativo-negativo, o passivo-positivo e o passivo negativo.

O caráter ativo-positivo, segundo ele, é adaptável e flexível. Ele executa com intensidade seu papel e se satisfaz muito com isso, indicando elevada autoestima e 
sucesso na relação com o ambiente. Ele atua com foco na produtividade e tem grande habilidade em fazer uso da racionalidade.

Já o ativo-negativo é compulsivo e experimenta uma contradição entre intenso esforço para executar suas atividades e baixa recompensa emocional para isso. Esse tipo de personalidade tem dificuldade de gerir seus sentimentos agressivos.

O passivo-positivo, por sua vez, tem como características a receptividade e o altruísmo. Trata-se de uma personalidade que busca o afeto como recompensa por ser agradável e cooperativo, em vez de pessoalmente assertivo.

Por outro lado, o caráter passivo-negativo é caracterizado principalmente pela omissão. Ele tem baixa autoestima e é focado em executar suas tarefas de forma obediente. Sua tendência é se retirar das situações, para escapar do conflito e da incerteza da política, fazendo uso de princípios vagos e mecanismos processuais.

Para categorizar os presidentes de acordo com sua tipologia, Barber (1972) adota um procedimento indutivo. Ele levanta alguns aspectos importantes do desempenho de ex-presidentes em termos de tipos de características, e depois extrapola os resultados dessas explicações, propondo algumas hipóteses gerais no sentido de que se pode esperar que candidatos com perfis semelhantes se comportem de maneira parecida. A partir dessa indução, surgem previsões gerais para cada um de seus quatro tipos de caracteres.

Assim, os ativos-positivos - Franklin Roosevelt, Harry Truman e Jonh Kennedy, de acordo com o autor - exibem forças pessoais especialmente em sintonia com a Presidência, pontos fortes que lhes teria permitido fazer com que o gabinete fosse um "motor do progresso". Embora sublinhando as virtudes do tipo ativo-positivo, Barber observa que, em sua pressa para fazer as coisas acontecerem, podem muito rapidamente e facilmente derrubar as "formalidades" que mantêm a ordem democrática no lugar (BARBER, 1972).

Os ativos-negativos - categoria em que estariam Woodrow Wilson, Herbert Hoover e Lyndon Baines Johnson - têm necessidade de impor seus hábitos e percepções políticas. Eles tendem a perseverar rigidamente em uma política desastrosa. Em relação a esse tipo, Barber lança a teoria da "propensão à tragédia", defendendo que são particularmente tendentes a um desempenho desastroso se eleitos. Barber vê o tipo ativonegativo como tendo dificuldade particular em se ajustar às exigências implícitas em 
situações de crise. Ele diz que Woodrow Wilson, Herbert Hoover e Lyndon B. Johnson parecem ter esquecido que o poder significa persuasão. Segundo Barber (1972), esses presidentes compartilharam um padrão comum de perfil: um processo de enrijecimento, com falta de habilidade política, uma insistência num curso de ação equivocado, apesar da forte evidência do erro. Cada um deles atuou para a construção de sua própria derrota e, nesse processo, prejudicou a situação do país como um todo.

Passivos-negativos - que seriam Calvin Coolidge e Dwight David Eisenhower representam o perigo de desvio. Eles deixam vagas a energização e o estímulo às possibilidades do seu papel. No entanto, em certas circunstâncias históricas, esse tipo pode oferecer um necessário respiro para a recuperação após um período de política frenéticos (BARBER, 1972).

Passivo-positivos - como William Howard Taft e Warren Gamaliel Harding agem se provocados, mas não iniciam nem "empurram" nada. No entanto, para um povo em busca de sentimento de comunidade, eles fornecem esperança e algum sentido de partilha e carinho (BARBER, 1972).

Várias observações e críticas são feitas em relação à teoria de Barber (Cf. GEORGE, 1974). Em primeiro lugar, empregar variáveis de personalidade para explicar ou prever o comportamento político de um presidente requer análise da inter-relação entre personalidade e fatores situacionais. Mas esses elementos que afetam o desempenho presidencial são numerosos e complexos, e que incluem diversas variáveis, o que torna o processo naturalmente difícil.

Além disso, os dados históricos utilizados para os diagnósticos variaram em quantidade e qualidade. Ou seja, pode ser que algumas análises tenham sido mais consistentes que outras menos fundamentadas. Também não ficam muitos claros quais foram os critérios utilizados para a seleção dos eventos que compuseram os diagnósticos.

Outro aspecto a ser destacado é que os tipos são apresentados como se fossem mutuamente excludentes, mas as pessoas podem ser, como Barber reconhece, a mistura de mais de uma das categorias. Isso complica a tarefa de utilizar a tipologia de diagnosticar um presidente e leva Barber para olhar para o tipo-tendência dominante exibido por cada um. 
Finalmente, em relação às tragédias relacionadas à personalidade ativo-negativa, elas estão ligadas a diferentes tipos de eventos políticos, fato que dificultaria a reprodução da metodologia de Barber, pois pode tornar arbitrária a definição, por parte do pesquisador, do que seria um episódio trágico (GEORGE, 1974).

De todo modo, afora as diversas críticas à teoria de Barber, seu estudo é considerado, além de original, importante esforço de categorização das personalidades dos presidentes.

Neusdat (1990) também se propôs a estudar o perfil dos presidentes, a partir de diversos eventos, ações presidenciais e suas repercussões. Sua primeira publicação de 1960, vista por alguns como ensaio de opinião ou manual para presidentes, cobriu as administrações de Harry Truman, Dwight David Eisenhower e Franklin Roosevelt. O autor argumenta que a base institucional do poder dos presidentes não é fonte exclusiva da efetividade e do sucesso do seu governo. Para ele, a liderança depende fortemente de seus traços de personalidade. Neustadt centra-se, então, em três traços que o presidente deve possuir para ter sucesso na Casa Branca, ou seja, conseguir aprovação e êxito nas suas políticas: o poder de persuadir, sua reputação profissional e seu prestígio público (NEUSTADT, 1990).

De acordo com ele, os norteamericanos costumam ver o presidente como o homem todo-poderoso que governa o país como o quer, de maneira autoritária, a partir do seu gabinete. Para Neustadt (199), contudo, um presidente deriva seu poder não só da autoridade constitucional, mas também de sua reputação e prestígio no país e no exterior. Como a mera autoridade não garante que a burocracia governamental o ajude na implementação de sua agenda política, o presidente é obrigado a influenciar os que o cercam com persuasão.

O poder de persuadir significa que o presidente não pode simplesmente mandar e esperar que suas ordens sejam obedecidas. Só porque ele quer algo feito não significa que os outros realizarão seus desejos. Nos Estados Unidos, há o princípio da separação dos poderes e a autonomia federativa, o que torna o poder muito disperso, aumentando a necessidade de permanente negociação e persuasão, e a consideração dos interesses e benefícios desejados pelos diversos atores (NEUSDAT, 1990). 
Outro aspecto do poder político é a reputação do presidente nos Estados Unidos e no exterior. Esse fator é importante pela dependência em relação à máquina burocrática - indivíduos e agências - para que seja implementada a agenda presidencial. Segundo Neustadt (1990), quanto melhor a reputação do presidente, mais fácil serão as negociações.

O último símbolo de poder presidencial investigado por Neustadt (1990) é o prestígio, ou seja, como o público o vê, facilitando ou dificultando o apoio dada às suas políticas. A opinião sobre o presidente contribui inclusive para o andamento das suas propostas no Congresso, além de ser um termômetro sobre a resistência do governo.

Neustadt (1990) também considera que um presidente deve pensar e agir de forma prospectiva, para que as decisões que toma hoje ajudem na sua capacidade de persuasão amanhã. Além disso, deve utilizar todo seu conhecimento para orientar suas decisões, as quais terão efeito direto sobre sua reputação e seu prestígio com o público. Segundo ele, a presidência não é um lugar para amadores, e a capacidade para assumi-la dificilmente pode ser adquirida sem profunda experiência em cargos políticos, sendo um lugar para os "homens da política", mas nem por isso para todos os políticos.

O estudo de Greestein (2000), por sua vez, baseado em entrevistas com expresidentes e pessoas ligadas a eles, teve o objetivo de identificar características que teriam contribuído ou prejudicado o desempenho na Casa Branca. Ele desenvolveu, então, seis títulos referentes a atributos que afetariam o desempenho do cargo presidencial.

O primeiro, que se refere à face da liderança presidencial, é a proficiência do Presidente como um comunicador público. O segundo, que diz respeito ao funcionamento interno da presidência, é a capacidade organizacional do presidente, isto é, sua habilidade de reunir a equipe e estruturar suas atividades de forma eficaz. Isso inclui a capacidade de montar a equipe e minimizar a tendência dos subordinados para dizer o que eles sentem e não o que ele quer ouvir. O terceiro e quarto aplicam-se ao presidente como operador político: sua habilidade e sua visão de política pública. O quinto é o estilo cognitivo com o qual o presidente processa os aconselhamentos e informações que chegam a ele. O sexto é a inteligência emocional, ou seja, a medida em que o presidente é capaz de gerenciar suas emoções e usá-las de maneira construtiva, ao invés de ser dominado por elas e prejudicar o seu desempenho público (GREENSTEIN, 2000). 
Os críticos das pesquisas sobre personalidade dos presidentes questionam o método e os pressupostos. Quanto ao primeiro aspecto, alegam que os estudos carecem de parcimônia conceitual e de rigor empírico. Para eles, as generalizações e os conselhos prescritivos são muitas vezes baseados em evidências limitadas, e as hipóteses são difíceis de serem testadas. Argumentam que a descrição acaba por substituir a coleta de dados orientada pela teoria, não produzindo resultados de pesquisas cumulativas (LYONS, 1997).

Sobre as premissas, eles afirmam que a presidência moderna está tão institucionalizada e prisioneira de restrições externas que a personalidade do ocupante teria pouca influência sobre os resultados políticos. Esse grupo reúne pluralistas como Robert Dahl e Theodore Lowi, e teóricos da escolha racional como Terry Moe (LYONS, 1997).

Lyons (1997) rebate as críticas ao afirmar que os argumentos partem de um pressuposto equivocado: que a análise da personalidade não se relaciona com a base institucional do poder presidencial. Ele defende que a abordagem de Neustadt (1990), por exemplo, é crucial para o entendimento do desenvolvimento da institucionalidade presidencial e para explicar por que algumas organizações são mais efetivas que outras. Para ele, o desenvolvimento do institucionalismo não torna obsoleta a abordagem sobre personalidade presidencial. Ao ignorar as implicações institucionais dos argumentos de Neustadt (1990), os neoinstituicionalistas estariam afastando uma abordagem conceitual que, adequadamente compreendida, fornece a base para um modelo institucionalista de análise do poder presidencial (LYONS, 1997).

Em função dos diversos constrangimentos institucionais, como o sistema de freios e contrapesos, e de todo o arcabouço jurídico-político que dá sustentação à Presidência, pode ser difícil perceber como a personalidade individual do presidente pode gerar efeitos nos outputs políticos, uma vez que ele não governa sozinho, embora seja a figura central do sistema. Nesse sentido, parece mais razoável considerar o perfil presidencial de maneira ampla, referindo-se ao núcleo duro do governo - que também pode ser chamado, por exemplo, de núcleo central ou centro de governo. Esse grupo político tende a reproduzir, em grande medida, o estilo do boss, além de seguir e implementar suas orientações, mas não se restringe a ele de forma individual.

No Brasil, ainda é escassa a literatura que trata do perfil dos presidentes e de sua assessoria mais próxima. Diferentemente do que ocorre nos Estados Unidos, a área de 
estudos presidenciais não tem sido tão explorada por aqui, embora os presidentes sejam atores chave do sistema político, dado que até os períodos históricos são tratados como referência ao presidente no poder. Inicialmente, a pesquisa sobre presidentes nos EUA recaía tanto sobre sua psicologia individual quanto os comportamentos e estilos de liderança. Nesses estudos, a metodologia incluía abordagens quantitativas e teoria dos jogos. Mais recentemente, as pesquisas passaram a focar no papel pessoal de cada um dos presidentes, sua relação com o ambiente político - Legislativo, Judiciário, burocracia, sociedade civil, etc -, bem como o contexto socioeconômico em que atuam (LASSANCE, 2015).

Em trabalho publicado pelo Banco Interamericano de Desenvolvimento (BID), Alesandro et al (2013) tratam dos centros de governo, definindo-o como o núcleo que apoia o boss nas funções de coordenação política e técnica, planejamento estratégico, monitoramento dos programas e comunicação. Nesse sentido, defendem que, embora os conceitos possam ser mais ou menos abrangentes quanto aos membros que integram essa equipe, é mais importante olhar para as suas funções do que propriamente para a sua composição ou localização estrutural. A área de finanças, por exemplo, tem atribuições mais ligadas à coordenação do que à prestação de serviços, o que caracteriza sua atuação como típica de centro de governo. Do mesmo modo, a autoridade orçamentária, aparentemente responsável por atividades de gestão de recursos, costuma participar do planejamento, formulação e acompanhamento das ações governamentais.

Inácio e Llanos (2003) afirmam que os presidentes são os atores políticos mais poderosos das democracias latino-americanas. Além de responderem diretamente à demanda do eleitorado, eles gozam de importantes poderes em vários domínios políticos, como a ingerência na agenda legislativa, o controle da alocação de recurso e a prerrogativa para nomear e demitir funcionários. Entretanto, mesmo os presidentes mais influentes contam necessariamente com a assistência técnica e o suporte político dos seus assessores mais confiáveis.

Segundo Lassance (2015), a atuação desse grupo tem se tornado cada vez mais relevante em função do aumento de atividades transversais que os governos têm tido que desempenhar, além de fatores como a atuação da mídia e a personalização das campanhas eleitorais. Todos esses elementos levariam cada vez mais à responsabilidade pessoal direta do chefe do Executivo pelas ações em todas as áreas de sua administração, que tem 
respondido a esse desafio fortalecendo o papel do centro de governo para assegurar o controle político sobre o gabinete e a burocracia.

A função primária dos centros de governo é a coordenação política, dada a dificuldade de um indivíduo acumular sozinho a função de direção das políticas públicas com o papel de articulação com os diversos atores, especialmente o Legislativo e os partidos políticos, mas também as organizações da sociedade civil, outros grupos de interesse e a opinião pública. Nos governos de coalizão, a coordenação política é mais complexa e requer permanente consultas sobre as políticas a serem lançadas. O centro de governo tem também o papel antecipar e gerenciar reações de grupos descontentes (ALESANDRO et al, 2013).

Para além da coordenação política, o núcleo duro atua também na supervisão dos processos de formulação e implementação de políticas públicas. Nesse aspecto, a falta de diretrizes centrais pode levar à incoerência ou mesmo contradições entre as ações, à duplicação de esforços e a diversos conflitos entre os órgãos. No entanto, os centros de governo diferem quanto ao grau de coordenação que fornecem aos seus governos. Uma questão que se coloca, nesse aspecto, é se a força e a centralização de decisões no centro de governo têm a ver com a visão do presidente sobre a autonomia ministerial (ALESANDRO et al, 2013).

Para traduzir suas plataformas eleitorais em programas governamentais, cabe ao núcleo central o planejamento estratégico do governo como um todo. Isso ocorre por meio do monitoramento da atuação dos órgãos e alinhamento das suas ações com as prioridades do chefe do Executivo, assegurando que os objetivos de cada um sejam suficientemente específicos e realistas. Cabe também a esse núcleo garantir que o orçamento esteja sincronizado e distribuído de acordo com a visão mais geral do governo. O estilo do chefe e a dinâmica política do seu gabinete, bem como o nível de especialização nos ministérios e centros de governo, influenciam a forma como o trabalho é conduzido. (ALESANDRO et al, 2013).

Em geral, os centros de governo reúnem dados para monitorar o desempenho dos órgãos e municiar o chefe do Executivo com informações para tomar decisões e realizar cobranças aos ministros. Em tese, o presidente precisa receber inputs fontes para formar suas posições e orientar os ministérios, mas a capacidade do núcleo duro de acompanhar a performance das áreas e de intervir quando os resultados não estão sendo alcançados 
depende da relação entre os ministros e o chefe do Executivo e do poder que este último delega ao centro de governo (ALESANDRO et al, 2013).

Quanto à função de comunicação e prestação de contas, o núcleo central interage com os órgãos para definir a apresentação de informações ao presidente e ao público em geral. Nesse sentido, o centro de governo escolhe quais dados de desempenho serão levados, resultando em uma tensão: algumas forças levam a proteger a imagem do chefe do Executivo a todo custo, enquanto outras se inclinam para a transparência (ALESANDRO et al, 2013).

Nos sistemas parlamentares, em que a responsabilidade ministerial é coletiva, o centro de governo atende não apenas ao primeiro-ministro, mas ao gabinete como um todo. No presidencialismo, ao contrário, os ministros atuam de acordo com as ordens do presidente, que os nomeia e decide se continuam em seus cargos. A autoridade, a responsabilidade final e prestação de contas ao eleitorado recaem, portanto, sobre o presidente. Desse modo, o centro de governo serve-o exclusivamente, ainda que suas funções beneficiem todo o governo (ALESANDRO et al, 2013, 2014).

Existem variações importantes entre os países na forma como os centros de governo são organizados para desempenhar suas funções, dependendo de disposições constitucionais, restrições institucionais e tradições administrativas. Também dentro de um mesmo país, cada chefe do Executivo estrutura seu núcleo de acordo com suas preferências pessoais ou realidades políticas, podendo variar de um mandato para outro, em caso de reeleição, ou até mudar no curso de uma mesma gestão (ALESANDRO et al, 2013).

Além da assessoria formal, Siavelis (2010) argumenta que os presidentes constroem ou dependem de redes informais de apoiadores que ajudam na relação com o Executivo, na proteção da imagem do chefe e nas diversas interações políticas. Essas estruturas não formais, muitas vezes, influenciam mais as decisões presidenciais do que alguns ministros. Transpondo o raciocínio do autor para a linha argumentativa aqui apresentada, é possível compreender que, embora não oficialmente designados, esses assistentes comporiam, ainda que informalmente, o chamado "núcleo duro" de governo.

A atuação desse centro de governo tende a refletir, portanto, o perfil, as escolhas e a dinâmica de trabalho do presidente, seja porque ele define assessores com 
personalidade mais parecida com a sua, seja porque essas pessoas acabam por reproduzir o comportamento do boss, ou mesmo porque tentam antecipar suas decisões, processando as situações e tomando cursos de ação tal como o chefe.

Neste trabalho, diferentemente das abordagens que recam sobre o perfil psicológico individual dos presidentes, a ideia do motorista está relacionada ao estilo de governar do núcleo duro de governo, que se manifesta nos diversos aspectos de sua atuação, como articulação política, liderança, gestão e comunicação. 


\section{HEMOGRAMA DA GOVERNABILIDADE}

Independentemente da corrente, os autores concordam que o presidencialismo de coalizão reflete em processos como a formação dos ministérios, o apoio legislativo às propostas e posições do Executivo, a disciplina partidária, o uso de medidas provisória, a definição da agenda legislativa e diversas outras variáveis (POWER, 2009, p.132). Esses elementos são, portanto, típicos da relação entre Executivo e Legislativo, e sua dinâmica diz muito a respeito da situação da interação entre esses Poderes. Com base nisso, serão apresentados, a seguir, alguns fatores considerados importantes para o teste diagnóstico do estado de saúde do presidencialismo de coalizão.

Segundo as denominadas Leis de Duverger, os sistemas majoritários de um turno tendem ao bipartidarismo, enquanto os sistemas majoritários de dois turnos e a representação proporcional conduziriam ao multipartidarismo. A maior parte dos autores, no entanto, entende esses postulados como probabilísticos e tendenciais, uma vez que há casos que fogem das regras. De todo modo, as regras proporcionais, em geral, conduzem a sistemas partidários fragmentados, permitindo a eleição de candidatos com inexpressiva votação.

Sobre o tema, Santos (1986) identifica que a fragmentação partidária estava no seu nível máximo no ano que antecedeu ao golpe de 1964. Na legislatura de 1946-1951, o número efetivo de partidos foi de 2,7; na legislatura de 1951-1955, 4,1; na de 19551959, 4,6; na de 1959-1963, 4,5; e na legislatura de 1963-1964, 4,6. Também segundo ele, quanto mais o Poder Legislativo se fragmentava, mais cadeiras eram ocupadas para os partidos de direita e esquerda e menos para os partidos de centro, caracterizando uma crescente polarização ideológica. Vários estudiosos previram equivocadamente que o Brasil se estabilizaria com um multipartidarismo moderado, com um sistema partidário mais reduzido (REBELLO, 2102).

Também segundo Santos (1986), as rupturas institucionais em regimes democráticos decorrem de crises de paralisia decisória, uma vez que esses processos abrem caminho para que determinados grupos tentem fazer uso de meios violentos e de mudanças ilegais nas regras do jogo para solucionar os impasses. Nesse tipo de situação, ocorre a intensificação e dispersão de preferências, além de fragmentação dos recursos políticos, o que estimula a formação de coalizões de veto ad hoc, dificultando 
enormemente a formação de maiorias governativas estáveis. Esse fenômeno resultaria da combinação do aumento do número de partidos em oposição ao governo, da radicalização das suas posições ideológicas e da diminuição do seu tamanho legislativo (AMORIM NETO, 2002).

Nos sistemas presidencialistas da América Latina, Deheza (1998) identificou que a maioria dos governos é de coalizão, em que os presidentes negociam com partidos por vários meios, especialmente pela distribuição de ministérios. A entrega de postos ministeriais tem o propósito de promover maioria no Congresso, recompensar o apoio recebido nas eleições ou construir acordos restaurativos entre os partidos.

Amorim Neto (2006), em estudo para identificar como as mudanças ministeriais afetam o comportamento legislativo, testando o impacto da composição do gabinete sobre as taxas de disciplina partidária, concluiu que, havendo correspondência entre o peso no Congresso e a participação ministerial, os partidos coligados tendem a se comportar de modo disciplinado nas votações em relação às preferências do Executivo. Essa cooperação se realiza, portanto, por meio de acordos de coalizão, que são a fonte dos altos níveis de sucesso legislativo dos presidentes brasileiros. Segundo o autor, as coalizões dependem fortemente de determinadas características na composição dos gabinetes, em especial os critérios pelos quais os presidentes selecionam ministros e alocam ministérios aos partidos - vale dizer, se os gabinetes são majoritários ou minoritários, e se a distribuição de pastas é proporcional ou não.

A formação dessas coalizões em troca de cargos recebidos no Executivo ocorre de forma coordenada com a atuação dos líderes partidários que organizam o comportamento dos parlamentares. Na rotina do parlamento, foram criados "padrões de organização próprios", de modo que os recursos e direitos seguem uma lógica partidária e não são distribuídos igualmente aos congressistas. Os líderes partidários são os representantes legítimos de toda a sua bancada e esse cargo confere ao congressista maiores poderes de ação e influência dentro do processo decisório (FIGUEIREDO; LIMONGI, 1998, 1999).

Os líderes detêm amplos poderes conferidos pelos regimentos das Casas, sendo responsáveis por controlar o fluxo dos trabalhos parlamentares, o que significa que os congressistas, agindo individualmente, não são capazes de alterar a dinâmica do processo legislativo. Desse modo, o caráter centrífugo e descentralizador das comissões seria 
neutralizado pelos partidos e seus líderes, que direcionam as matérias para o plenário a qualquer momento, por intermédio da aprovação do requerimento de urgência (FIGUEIREDO; LIMONGI, 1998, p. 92).

Segundo Santos (2002), há duas correntes sobre o comportamento dos partidos na arena legislativa. Uma delas afirma que eles são indisciplinados e de atuação imprevisível, uma vez que estão focados nos seus próprios interesses. A outra defende que os partidos são disciplinados e com conduta previsível e que, seus membros não possuem poder suficiente para perseguir suas preferências individuais. Os dados empíricos apresentados pelo autor mostram grau alto de disciplina partidária nas votações em plenário, em relação às orientações dos líderes.

Para Power (2011), as coalizões atuais não são apenas superdimensionadas - com número bem superior ao necessário para as aprovações - como são desconexas compostas por partidos sem correspondência ideológica e programática. Essas características indicam o oportunismo dos parlamentares de se alinharem ao presidente e refletem a expectativa do governo em relação à indisciplina. Segundo o autor, coalizões superdimensionadas e desconexas constituem uma "apólice de seguro" para o Executivo.

Em geral, há orientação do Executivo, por meio do líder do governo, quanto à sua preferência sobre as matérias em votação. Há proposições, por exemplo, que exigem votações nominais, em que os parlamentares manifestam expressamente seus votos. Elas diferenciam-se das simbólicas, em que há manifestação física, como levantar a mão ou permanecer de pé, e das secretas, nas quais os congressistas não explicitam suas posições. As votações nominais, portanto, evidenciam as posições individuais dos parlamentares, em detrimento da manifestação da bancada ou dos partidos, abrindo margem para manifestações contrárias às orientações dos líderes. A tabela abaixo apresenta as situações nas quais o plenário da Câmara dos Deputados brasileira utiliza a votação individual identificada (votação nominal): 
Tabela 2 - Situação e quórum para deliberação nas votações nominais, por tipo de proposição

\begin{tabular}{|l|c|l|}
\hline \multicolumn{1}{|c|}{ Tipo de Proposição } & Situação & \multicolumn{1}{|c|}{$\begin{array}{c}\text { Quórum para } \\
\text { Deliberação } \\
\text { (votos necessários) }\end{array}$} \\
\hline Emenda Constitucional & Sempre & $3 / 5$ (308 votos) \\
\hline Lei Complementar & Sempre & $1 / 2+1$ (257 votos) \\
\hline $\begin{array}{l}\text { Legislação Ordinária/Medida } \\
\text { Provisória/Requerimento } \\
\text { Parlamentar }\end{array}$ & $\begin{array}{c}\text { quando solicitada por pelo } \\
\text { menos 31 deputados }\end{array}$ & maioria dos presentes \\
\hline
\end{tabular}

Fonte: Nicolau (2000), a partir do Regimento Interno da Câmara dos Deputados.

Também relacionado ao processo legislativo, um dos principais indicadores que demonstram o nível de articulação entre governo e Legislativo é a aprovação dos projetos de lei de iniciativa do Executivo. Para além das propostas enviadas ao Congresso pelo governo, a produção legislativa como um todo é elemento que sinaliza o andamento das ações governamentais. Em seu estudo sobre os indícios de ingovernabilidade, por exemplo, Santos (1986) encontrou evidências de paralisia decisória no Brasil, em 1963, isto é, às vésperas do golpe: a taxa de aprovação de projetos de lei caiu para 0,07 neste ano, enquanto havia atingido os valores de 0,13, 0,13, 0,15 e 0,14, em 1959, 1960, 1961 e 1962, respectivamente.

Seguindo essa lógica, o veto também é forte indicativo do conflito entre Executivo e Legislativo, pois sinaliza incapacidade de construção de consenso na arena legislativa, conduzindo o problema "para a caneta" do presidente. O ato de vetar uma proposta, portanto, é medida extrema, de alto custo e possui potencial gerador de efeitos colaterais na relação entre os poderes.

Outro termômetro importante para se medir a coordenação entre Executivo e Legislativo diz respeito à aprovação das medidas provisórias enviadas ao Congresso, que podem ser vistas como mecanismos de delegação dentro do presidencialismo brasileiro (AMORIM NETO; TAFNER, 2002). Embora o recurso a esses atos normativos demonstre o poder de agenda do presidente, tais propostas precisam ser submetidas ao crivo do Parlamento antes de serem convertidas em lei. Nesse processo, o Executivo sempre deseja que elas sejam aprovadas integralmente, mas não raro são alteradas, rejeitadas ou não votadas, perdendo sua eficácia. Logo, mesmo as medidas provisórias, versão mais extrema da força do Executivo, precisam passar pelo crivo do Legislativo, o 
que requer do presidente capacidade de cooperação com os líderes dos partidos, pois "sem o apoio da maioria, presidentes, simplesmente, não governam" (LIMONGI, 2006, p. 245).

Do mesmo modo, a rotatividade dos ministros é evidência de instabilidade do governo e, portanto, de risco de paralisia decisória. A equação é simples: quanto mais volúvel a permanência dos ministros em seus postos, menos decisões tomam. Durante a presidência de Dutra, a taxa de estabilidade ministerial foi de 0,36; em Vargas, 0,32; em Kubitschek, 0,38; e em João Goulart, 0,13 (SANTOS, 1986).

Um dos instrumentos fundamentais utilizado pelo Executivo para barganhar com o Congresso são as emendas parlamentares. Até 2014, o governo gozava de discricionariedade para executar ou não as propostas, tendo, portanto, condições de jogar com essa prerrogativa de acordo com suas necessidades de negociação com o Congresso. Naquele ano, contudo, o governo sofreu uma importante derrota, que pode ser vista como sinal da sua fragilidade. Com aprovação do denominado "orçamento impositivo", a execução das emendas passou a ser obrigatória, o que retirou do Executivo uma das suas essenciais moedas de troca com o Legislativo.

Logo, a partir desses e de outros elementos considerados importante sinalizadores da situação da relação entre Executivo e Legislativo, elegeu-se um conjunto de fatores que serão analisados no âmbito do "hemograma". Na tabela a seguir, estão listados as dimensões e os indicadores que compõem esse teste diagnóstico. A posição das setas, cuja compreensão ficará mais clara na seção seguinte, representa que tipo de comportamento de cada indicador vai sinalizar menor governabilidade:

- seta para cima ( $\uparrow)$ : o aumento no resultado do indicador significa redução da governabilidade;

- seta para baixo $(\downarrow)$ : a diminuição no resultado do indicador significa redução da governabilidade. 
Tabela 3 - Dimensões e indicadores de governabilidade

\begin{tabular}{|c|c|c|}
\hline DIMENSÕES & INDICADORES & $\downarrow$ Governabilidade \\
\hline \multirow{3}{*}{$\begin{array}{c}\text { Produção e aprovação de projetos } \\
\text { de lei }\end{array}$} & Taxa de participação & Depende* \\
\hline & Taxa de sucesso & $\downarrow$ \\
\hline & Taxa de dominância & $\downarrow$ \\
\hline Vetos presidenciais & Percentual de projetos vetados & $\uparrow$ \\
\hline Aprovação de medidas provisórias & Taxa de conflito em medidas provisórias & $\uparrow$ \\
\hline \multirow{2}{*}{ Características da coalizão } & Tamanho proporcional da coalizão & $\downarrow$ \\
\hline & Disciplina da coalizão & $\downarrow$ \\
\hline Grau de coalescência & Taxa de coalescência & $\downarrow$ \\
\hline \multirow{2}{*}{ Rotatividade de ministros } & Geral & $\uparrow$ \\
\hline & Articuladores com o Congresso & $\uparrow$ \\
\hline \multirow[b]{2}{*}{ Fragmentação partidária } & Número efetivo de partidos políticos & $\uparrow$ \\
\hline & $\begin{array}{l}\text { Número de partidos com menos de dez } \\
\text { deputados }\end{array}$ & $\uparrow$ \\
\hline $\begin{array}{c}\text { Aprovação do orçamento } \\
\text { impositivo } \\
\end{array}$ & Momento em que houve a mudança de regra & NA \\
\hline
\end{tabular}

* Conforme será abordado de forma mais detalhada na próxima seção, para uma avaliação mais consistente da relação entre governabilidade e taxa de participação, é necessário cotejar este indicador com outros fatores.

Fonte: Elaboração própria

A seguir, serão apresentados resultados e análises sobre cada um dos indicadores de governabilidade propostos na tabela.

\subsection{Produção e aprovação de projetos de lei}

Segundo Limongi (2006), os principais indicadores para caracterizar os governos parlamentaristas são a taxa de sucesso das iniciativas do Executivo, que é a proporção entre o que é aprovado sobre o total enviado por este poder, e a taxa de dominância, que consiste na divisão das leis de iniciativa do Executivo pelo total de leis aprovadas no período.

De acordo com levantamento realizado por Hermann e Mendel (1976; 1986), no âmbito do Inter-Parliamentary Union, essa taxa sempre costuma girar em torno dos $90 \%$. O governo inglês, por exemplo, aprovou $93 \%$ das propostas que submeteu ao parlamento entre 1971 e 1976, e $92 \%$ entre 1978 e 1982. A dominância, por sua vez, foi de $83 \%$ e $84 \%$ em cada um desses períodos. O estudo demonstra que, na Dinamarca, os percentuais variaram entre 88 e 99\%. A Finlândia, que adota a representação proporcional com lista aberta, também registra valores que oscilam entre 84 e $99 \%$. 
Aplicando os indicadores ao Brasil, Limongi (2006) identifica que, de 1988 a 2006, o sucesso do Executivo, considerando a aprovação durante o mandato do Presidente que enviou as propostas, foi superior a $70 \%$. As diferenças entre presidentes são pequenas e independem da sua base de apoio. Collor aprovou $65 \%$ dos projetos que submeteu, Itamar alcançou $66 \%$ e os demais presidentes ficaram acima dos $70 \%$.

A taxa de dominância para o mesmo período é de $85,6 \%$, também sem grandes variações entre os mandatos. Collor e Sarney atingem em torno de 77\%, Itamar e Lula estão acima dos 90\%, e FHC consegue $85 \%$. Comparando com o período democrático anterior, o sucesso do Executivo entre 1949 a 1964 foi de 29,5 \%. Quanto às taxas de dominância, 39\% dos projetos de lei aprovados foram de iniciativa do Executivo. As enormes diferenças entre os dois períodos decorrem do arcabouço constitucional (LIMONGI, 2006).

A partir dos dados sobre propostas de medidas provisórias, leis ordinárias, leis complementares, leis orçamentárias e emendas constitucionais, foram calculadas aqui três taxas:

1) de participação: percentual de projetos de inciativa do Executivo sobre o total de projetos tramitados

2) de dominância: percentual de projetos de iniciativa do Executivo aprovados em relação ao total de projetos aprovados;

3) de sucesso: percentual de projetos de iniciativa do Executivo aprovados em relação ao total de projetos de inciativa do Executivo;

Os dados abaixo permitem a visualização do peso da participação do Executivo no conjunto das propostas que tramitam no Congresso: 
Gráfico 1 - Número de propostas enviadas ao Congresso, por mandato, de 1995 a 2016

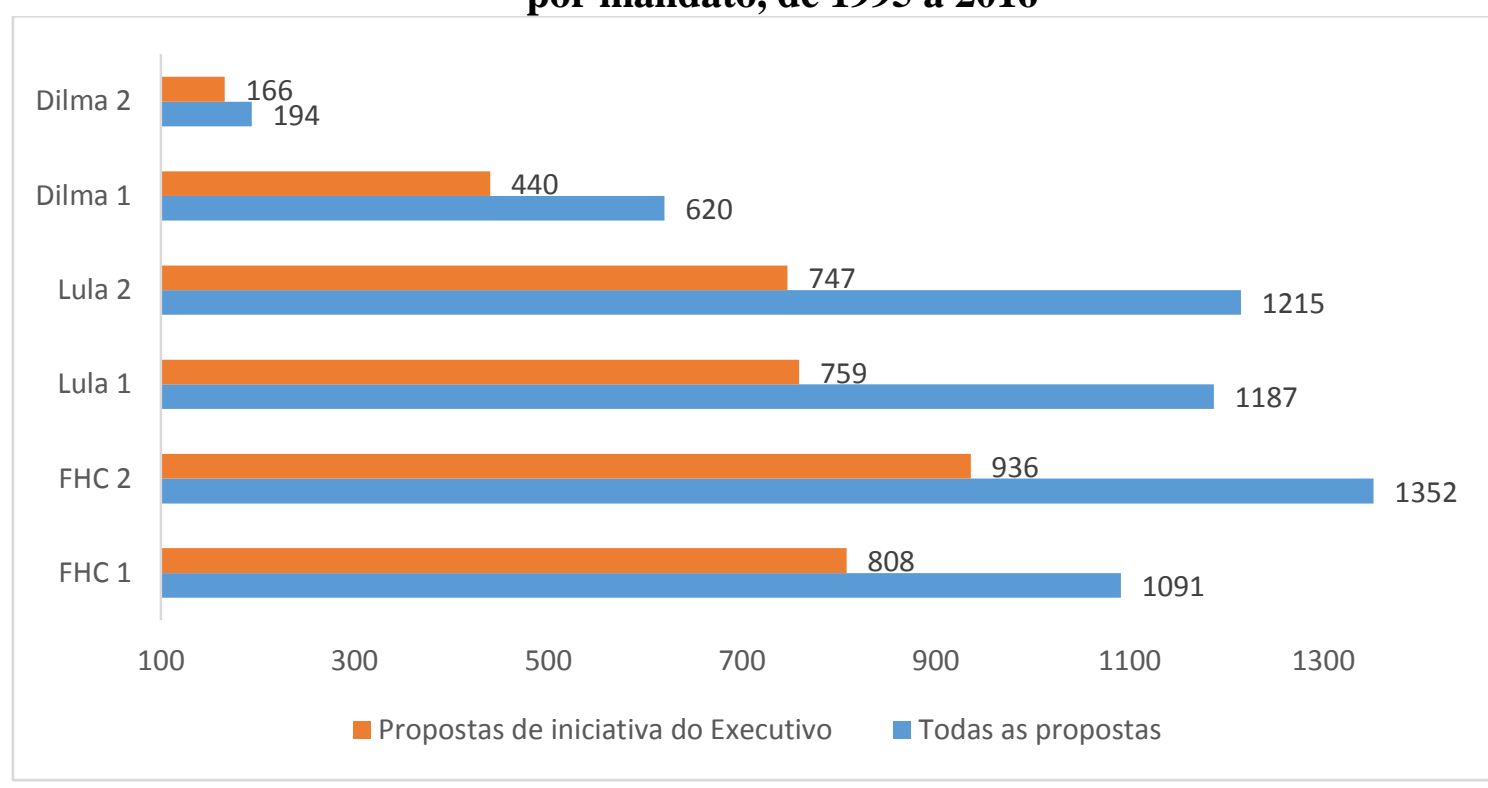

Fonte: Elaboração própria, a partir Banco de Dados Legislativos do CEBRAP. Acesso em 23/11/2016.

Em termos percentuais, a participação do Executivo em relação ao envio de propostas, em cada mandato, foi a seguinte:

\section{Gráfico 2 - Taxa de participação do Executivo, por mandato, de 1995 a 2016}

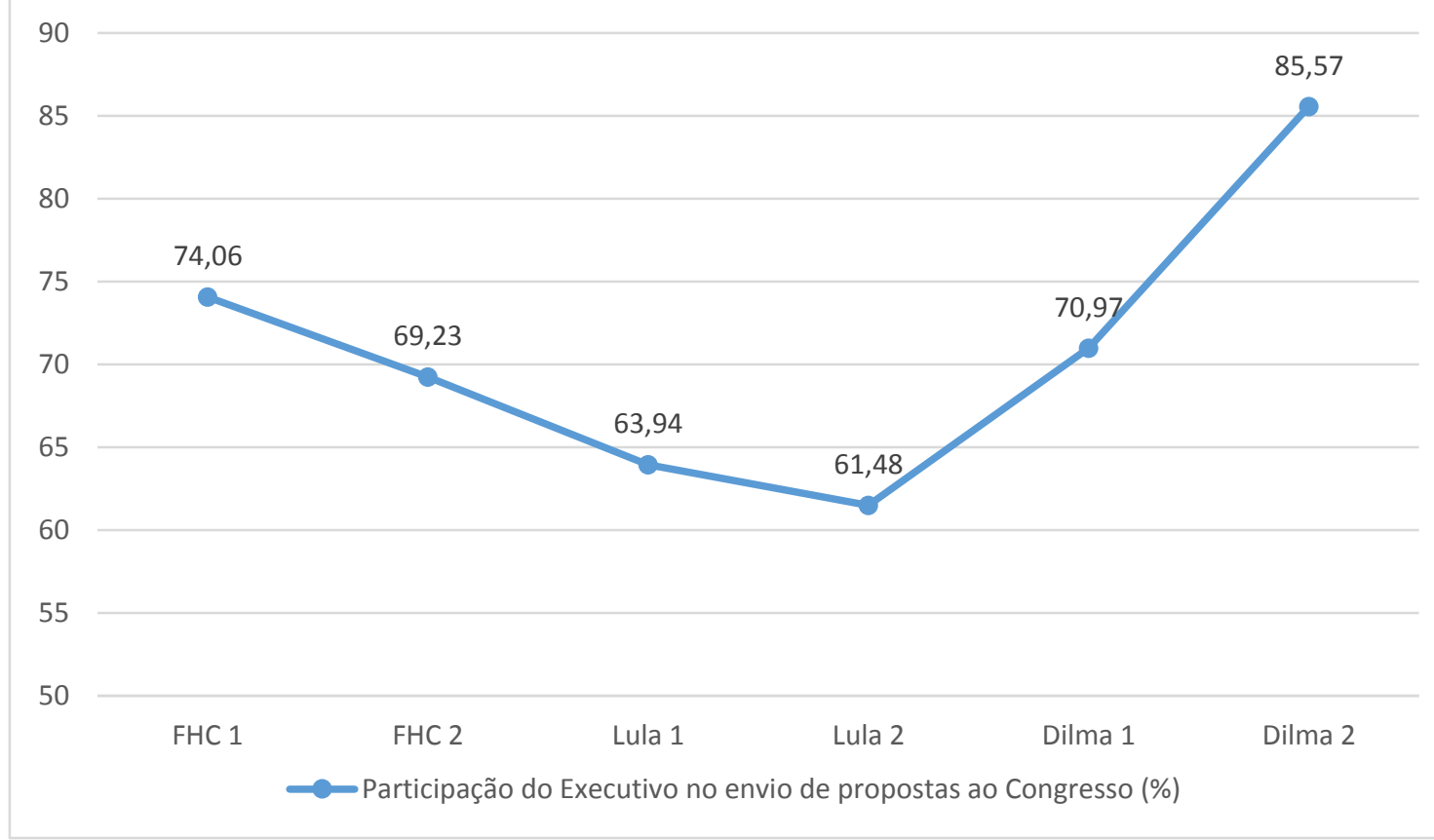

Fonte: Elaboração própria, a partir Banco de Dados Legislativos do CEBRAP. Acesso em 23/11/2016. 
Apesar de FHC, em seu segundo governo, ter enviado uma quantidade maior de propostas ao Congresso, os números absolutos dele e de Lula, nos dois mandatos, não são muito destoantes, variando entre 750 e 930 projetos, em universos de 1100 a 1300, aproximadamente. Em termos percentuais, de FHC 1 a Lula 2 observa-se um movimento de decréscimo de participação do Executivo, indo de 74 para 61,5\%. A partir de Dilma 1, contudo, notam-se dois novos fenômenos, ainda que se considere a saída da Presidenta antes do término regular do segundo mandato: i) a diminuição do envio de projetos ao Congresso, seja pelo Executivo ou pelos outros Poderes; ii) o aumento percentual de participação do Executivo, alcançando o patamar de mais de $85 \%$.

Em relação à taxa de sucesso, que consiste no percentual de projetos aprovados em relação ao total apresentado pelo Executivo, os resultados estão apresentados a seguir:

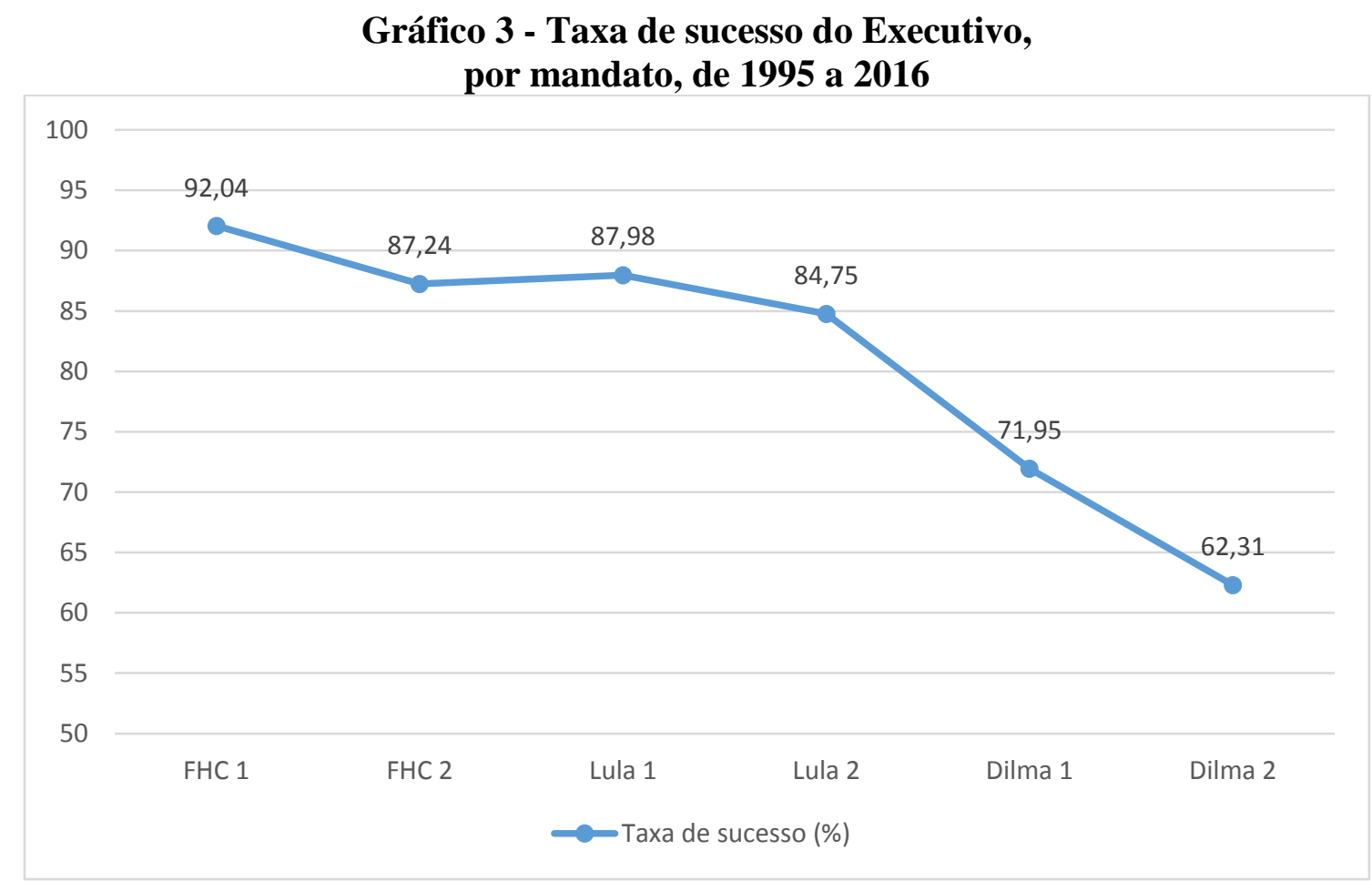

Fonte: Elaboração própria, a partir do Banco de Dados Legislativos do CEBRAP. Acesso em 23/11/2016.

Como o objetivo é comparar a força do Executivo na relação com o Legislativo, por mandato presidencial, interessa saber se o projeto enviado por determinado Presidente foi aprovado durante o seu governo. Logo, os cálculos realizados aqui consideraram esse recorte. A partir dos dados acima, verifica-se um alto percentual alcançado por FHC 1 (92\%), seguido por uma certa estabilidade no seu segundo governo e nos dois mandatos 
de Lula, oscilando entre 88 e $85 \%$. A redução mais aguda ocorre em Dilma I, com $71,95 \%$, fechando o seu segundo governo com $62,31 \%$.

Quanto aos projetos do Executivo aprovados em relação ao total de propostas aprovadas, que consiste na denominada "taxa de dominância", tem-se o seguinte quadro:

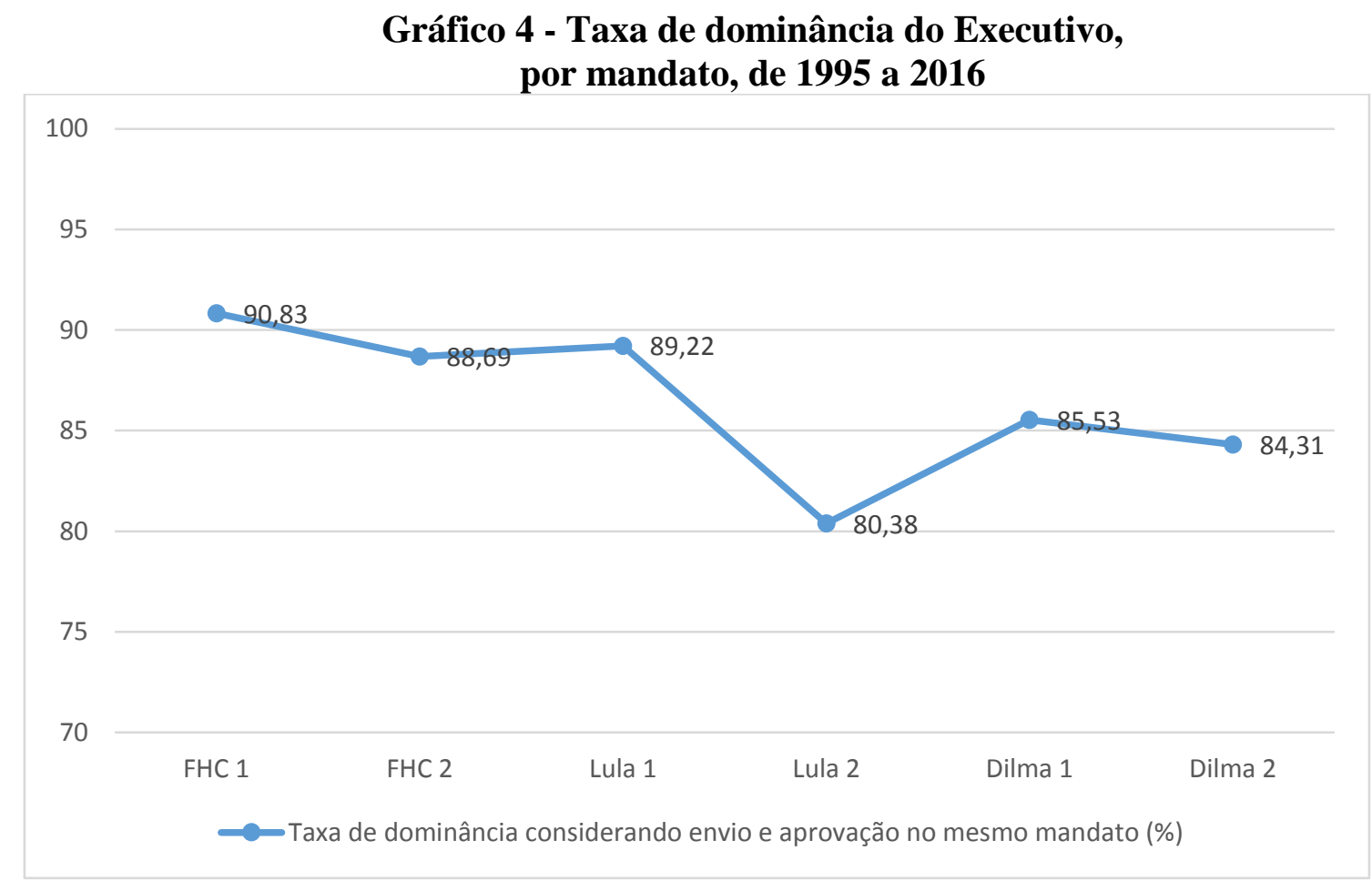

Fonte: Elaboração própria, a partir do Banco de Dados Legislativos do CEBRAP. Acesso em 23/11/2016.

Conforme Limongi e Figueiredo já haviam previsto (2006), os dados demonstram a proeminência do Executivo na agenda legislativa, sendo responsável, em todos os mandatos analisados, pela autoria de mais de $80 \%$ dos projetos aprovados. A taxa mais baixa, mas não tão distante das demais, ocorreu no segundo mandato de Lula.

Sintetizando os resultados dos cálculos para as três taxas, tem-se o seguinte quadro: 


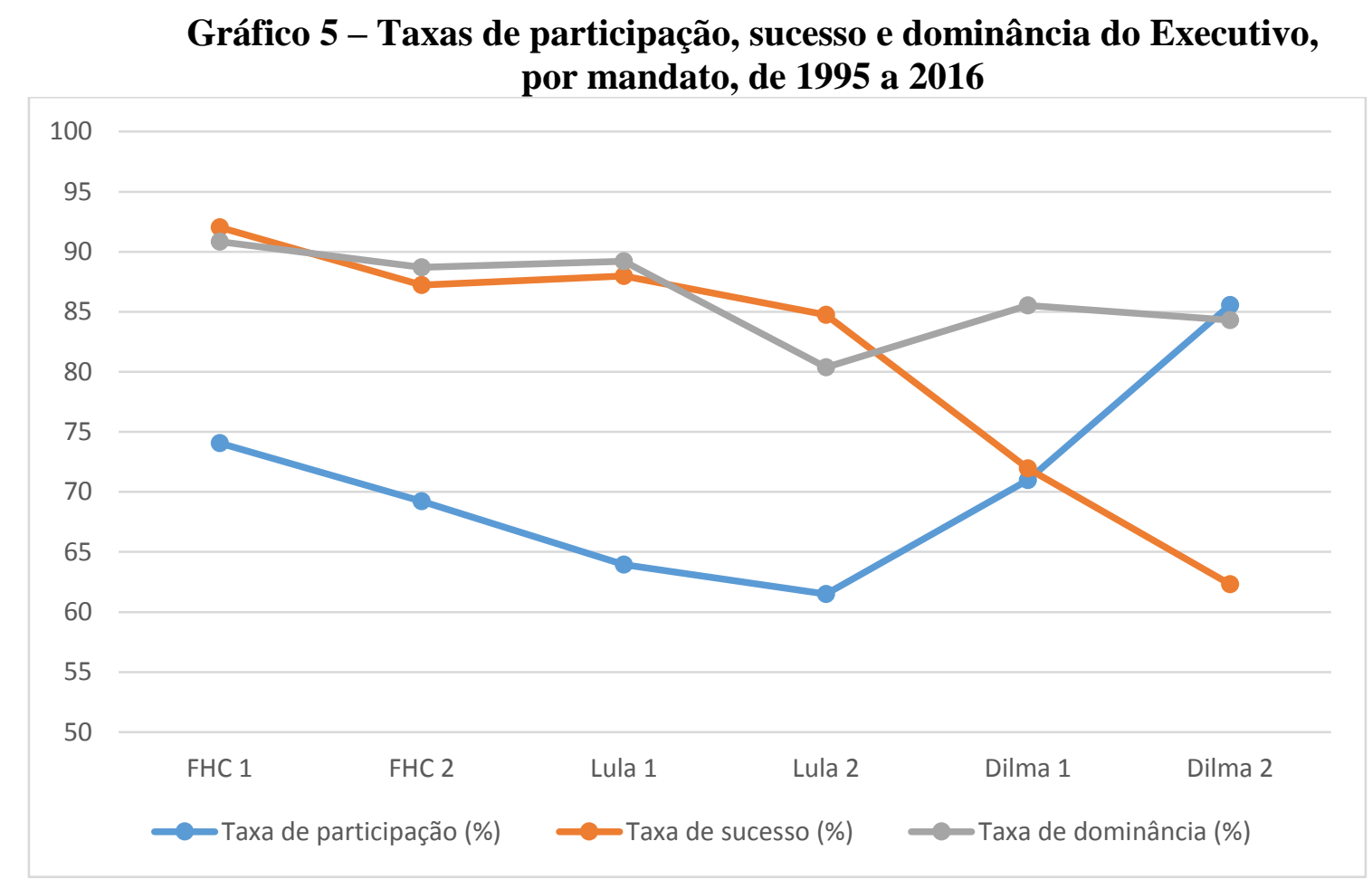

Fonte: Elaboração própria, a partir do Banco de Dados Legislativos do CEBRAP. Acesso em 23/11/2016.

A análise do gráfico traz algumas revelações a respeito das taxas ali apresentadas. A de dominância não apresenta variações significativas entre os mandatos, permanecendo numa constante de valores expressivos, entre 80 e $90 \%$, o que indica a manutenção de um padrão de alto peso dos projetos do Executivo no total de propostas aprovadas. Ou seja, o Congresso processa e avaliza muito mais os projetos do governo do que os seus próprios.

O gráfico permite também identificar um outro fenômeno curioso: após o segundo mandato de Lula, as taxas de sucesso e de participação mudaram a direção do comportamento, invertendo as tendências que vinham tendo até então. A partir do primeiro governo Dilma, portanto, o Executivo aumentou sua participação no envio de propostas (taxa que vinha caindo) e reduziu o seu sucesso na aprovação (taxa que vinha aumentando). No final do segundo mandato de Dilma, esses valores foram especialmente significativos, o que parece indicar uma situação em que o governo teria aumentado a sobrecarga de projetos sobre o Parlamento, insistindo pela implementação de sua agenda, e o Congresso respondeu de maneira radical, travando cada vez mais a pauta do Executivo. 


\subsection{Vetos presidenciais}

Os vetos representam situações em que a discordância entre o Executivo e o Parlamento acerca de determinado tema não foi solucionada durante o processo legislativo. Não havendo negociação, o conflito é levado, portanto, para a caneta do Presidente, que tem a prerrogativa de se manifestar contrariamente ao conteúdo final que chega para sua aprovação.

Embora o veto integral sinalize a divergência em seu nível mais agudo, o parcial também é indicativo de impasse, podendo recair sobre dispositivos centrais do projeto. Sendo assim, ainda que em graus diferentes, as duas modalidades de veto implicam custos ao presidente perante o Congresso e, portanto, devem ser consideradas medidas sensíveis.

Nesse sentido, o veto pode ser entendido como caso extremo de dissenso entre os dois Poderes. Por essa razão, o indicador "percentual de vetos" - parciais ou integrais de leis ordinárias e complementares ${ }^{5}$ foi calculado para o período de 1995 a 2016, a partir dos dados disponíveis no site do Congresso Nacional e no Portal da Legislação da Presidência da República.

\footnotetext{
${ }^{5}$ As medidas provisórias serão analisadas à frente de maneira mais detalhada.
} 
Gráfico 6 - Número de vetos por ano, de 1995 a 2016

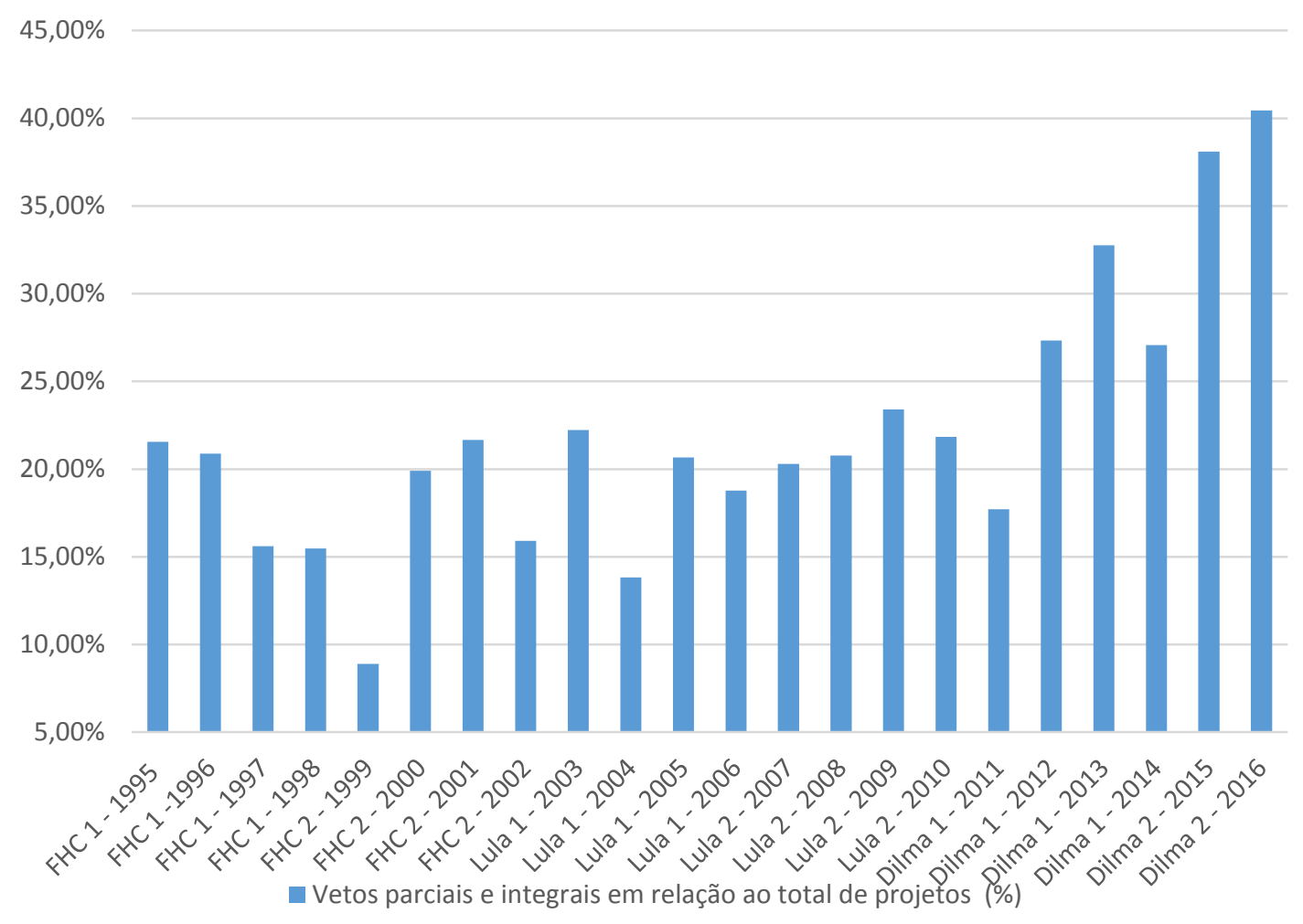

Fonte: Elaboração própria, a partir dos dados disponíveis no site do Congresso Nacional e no Portal da Legislação da Presidência da República. Acesso em 15/08/2016.

Com outra visualização gráfica, que talvez expresse melhor o comportamento do fenômeno no tempo, tem-se a seguinte curva: 
Gráfico 7 - Número de vetos por ano, de 1995 a 2016

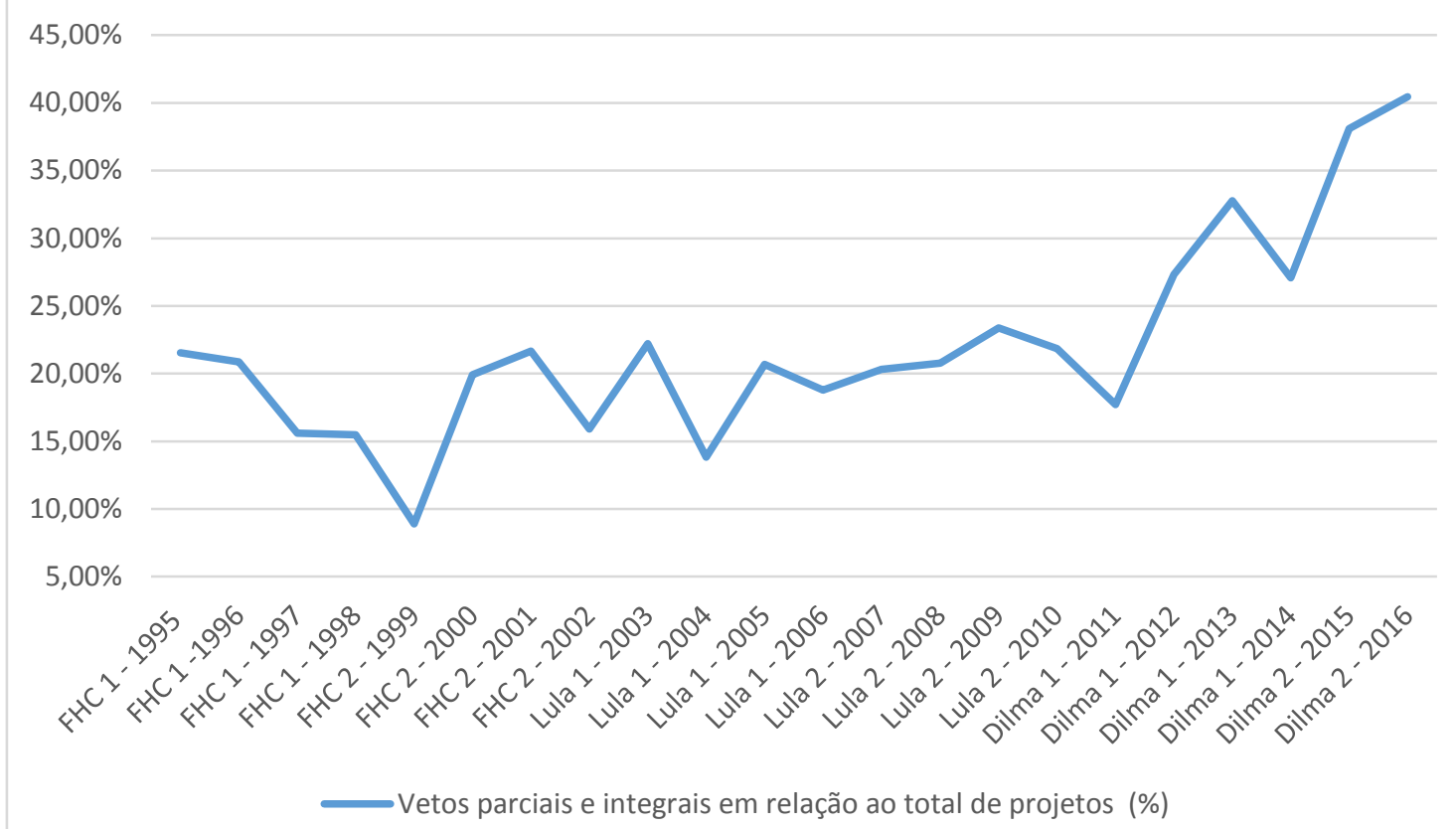

Fonte: Elaboração própria, a partir dos dados disponíveis no site do Congresso Nacional e no Portal da Legislação da Presidência da República. Acesso em 15/08/2016.

Fazendo os mesmos cálculos por mandato, os resultados são os seguintes:

\section{Gráfico 8 - Número de vetos por mandato, de 1995 a 2016}

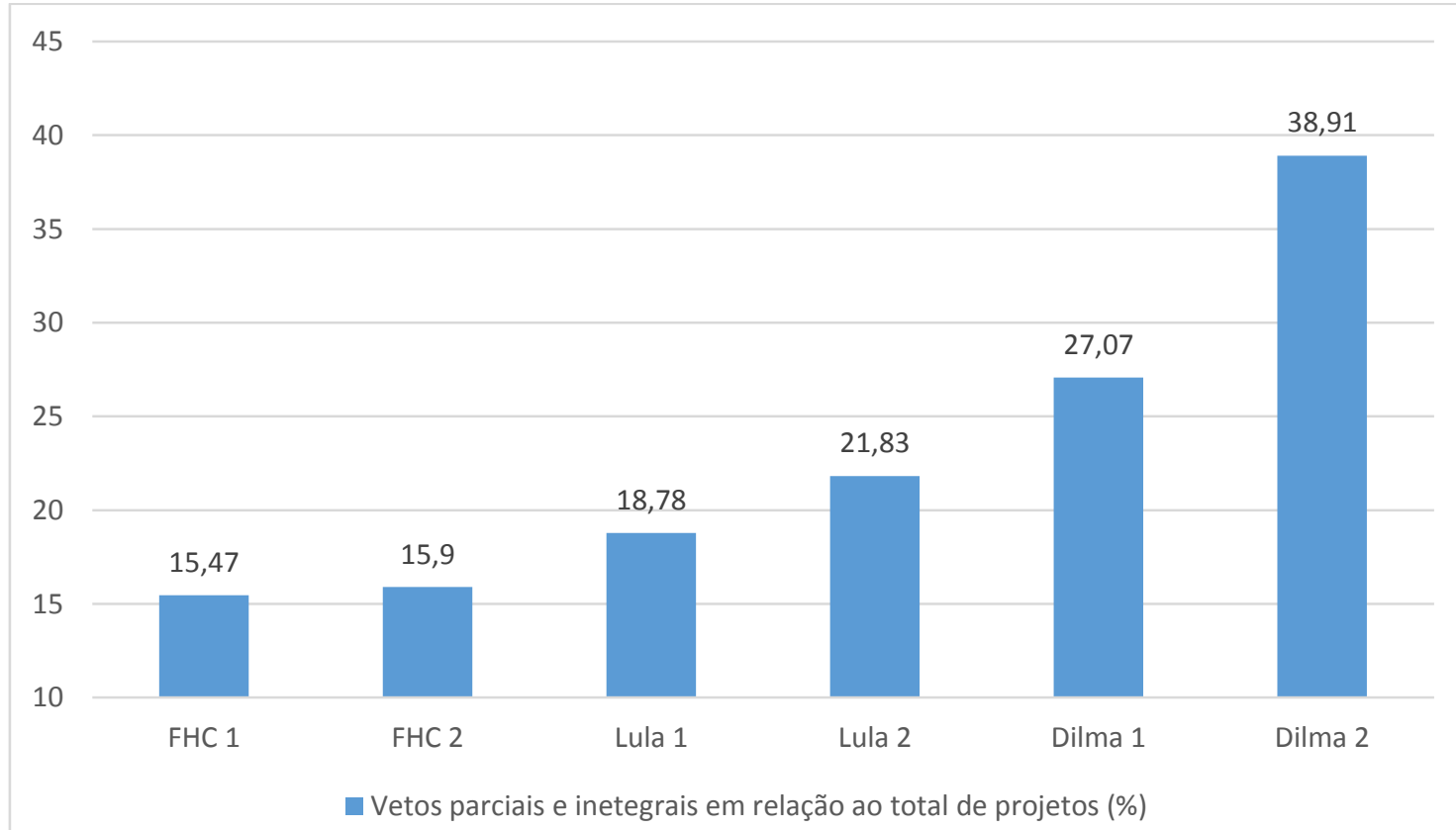

Fonte: Elaboração própria, a partir dos dados disponíveis no site do Congresso Nacional e no Portal da Legislação da Presidência da República. Acesso em 15/08/2016. 
Os dados demonstram que, nos governos de FHC e Lula, o percentual de projetos vetados oscila entre 15,5 e $22 \%$, aumentando paulatinamente de um mandato para outro. De Lula 2 para Dilma 1, há um aumento de 5 pontos percentuais, totalizando mais de $27 \%$ de projetos vetados. No segundo mandato, os vetos recaem sobre quase $40 \%$ dos projetos.

Por ser uma medida extrema de interferência do presidente do processo legislativo, o aumento de vetos indica a ampliação da necessidade de recurso a essa ferramenta. Ou seja: nos mandatos Dilma, em especial no segundo, há indícios de maior dificuldade do Executivo em vencer as disputas no âmbito do Legislativo, seja por diminuição da base, desorganização da coalizão ou descoordenação entre governo e Parlamento. De todo modo, o fenômeno demonstra um abalo importante na força da presidenta no Congresso.

\subsection{Aprovação de medidas provisórias}

A medida provisória é um tipo de ato normativo editado pelo presidente da República em situações de relevância e urgência, produzindo efeitos imediatos, mas com necessidade de aprovação do Congresso para que continue a produzir efeitos. Logo, o Executivo tem especial interesse em sua rápida aprovação.

Após a edição da MP pelo presidente, o Parlamento pode manifestar sua discordância em relação à medida i) rejeitando-a, ii) não realizando a votação dentro do prazo constitucional, implicando a perda de sua eficácia ou iii) alterando o texto de forma contrária aos interesses do Executivo, levando ao presidencial. Logo, a partir dos dados brutos disponibilizados pelo Centro Brasileiro de Estudos Legislativos, buscou-se calcular o conflito entre Executivo e Legislativo em relação às medidas provisórias.

Para isso, propõe-se aqui um novo indicador, denominado "conflito nas medidas provisórias", a partir do somatório de dois fenômenos:

- Para captar a discordância do Legislativo em relação à posição do Executivo: MPs não votadas e as rejeitadas pelo Congresso.

- Para captar a discordância do Executivo em relação à posição do Executivo: MPs vetadas pelo Presidente após voltarem do Congresso, integral parcialmente. 
Somados os quantitativos de MPs enquadradas nas situações acima, em cada mandato, compara-se o resultado com o total de Medidas enviadas por cada governo. A partir desse cálculo, foram obtidos os seguintes percentuais:

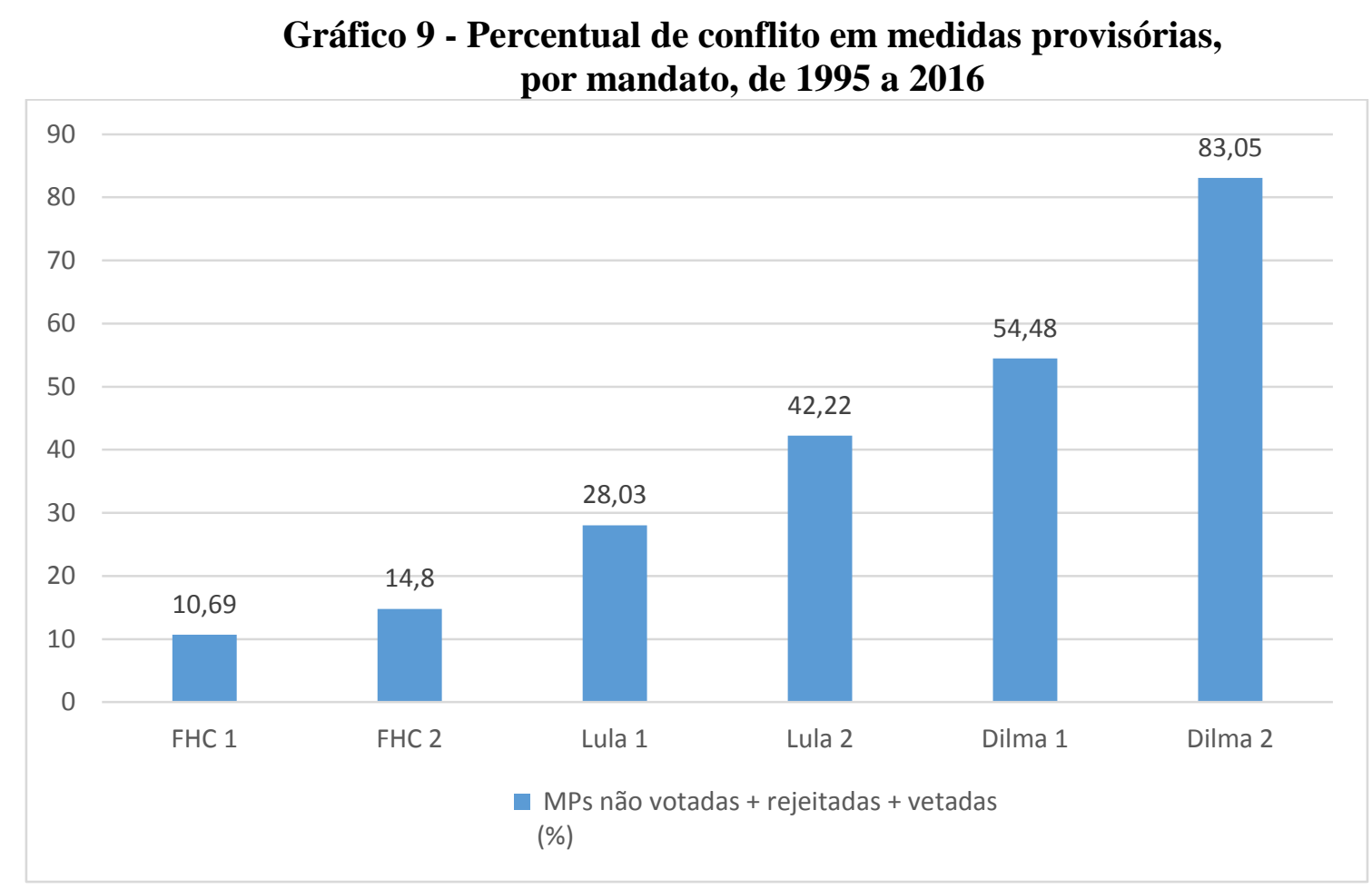

Fonte: Elaboração própria, a partir do Banco de Dados Legislativos do CEBRAP. Dados brutos recebidos em 30/08/2016.

A partir desses resultados, observa-se que, do mesmo modo como ocorre com os vetos, há um aumento progressivo das situações de conflito ou não-negociação entre Executivo e Legislativo. No segundo mandato de Lula, o percentual supera 40\%; em Dilma 1, há conflito em mais da metade dos casos, chegando a $83 \%$ em seu segundo mandato. Verifica-se, pois, um aumento importante de divergência entre os dois poderes nos governos Dilma 1 e 2.

\subsection{Características da coalizão}

Um dos indicadores mais básicos para a mensuração do apoio ao governo é o tamanho da coalizão. Grosso modo, esse dado indica com quantos parlamentares o Executivo pode contar para aprovar de projetos de seu interesse e impedir o 
prosseguimento de propostas contrárias à sua posição. Evidentemente, o número puro de parlamentares não basta para a garantia do apoio, mas é pressuposto para o andamento das negociações.

Nesse sentido, segue o retrato do tamanho das coalizões governistas no início e no fim de cada mandato:

Gráfico 10 - Número de deputados da coalizão, por mandato, de 1995 a 2016

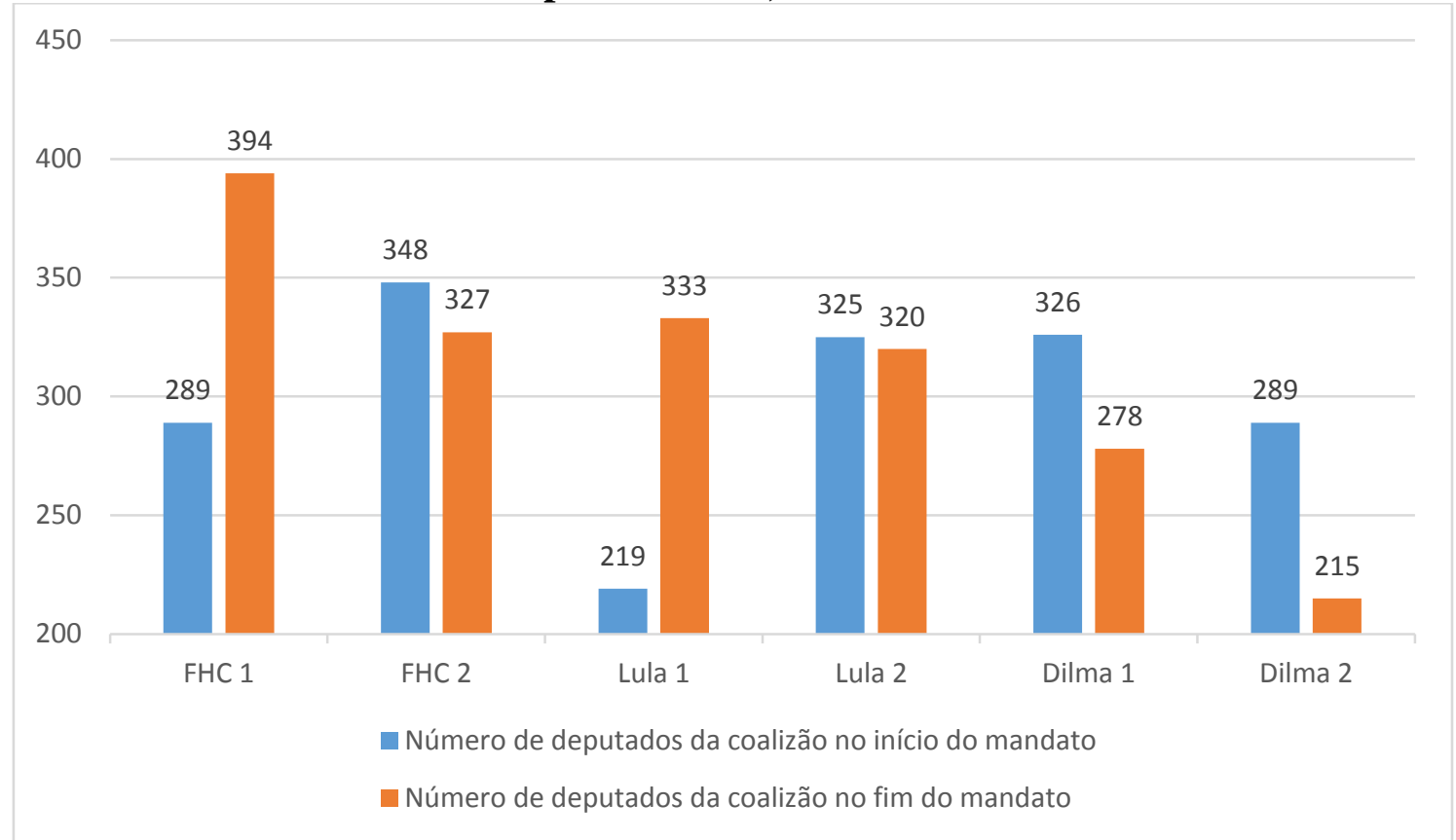

Fonte: Elaboração própria, a partir do Banco de Dados Legislativos do CEBRAP. Dados brutos recebidos em 11/11/2016.

Comparando-se o tamanho da coalizão, no fim de cada mandato, em relação ao total de deputados da Câmara, no mesmo período, os resultados são os seguintes: 
Gráfico 11 - Proporção entre o número de deputados da coalizão e o total de deputados, no fim dos mandatos, de 1995 a 2016

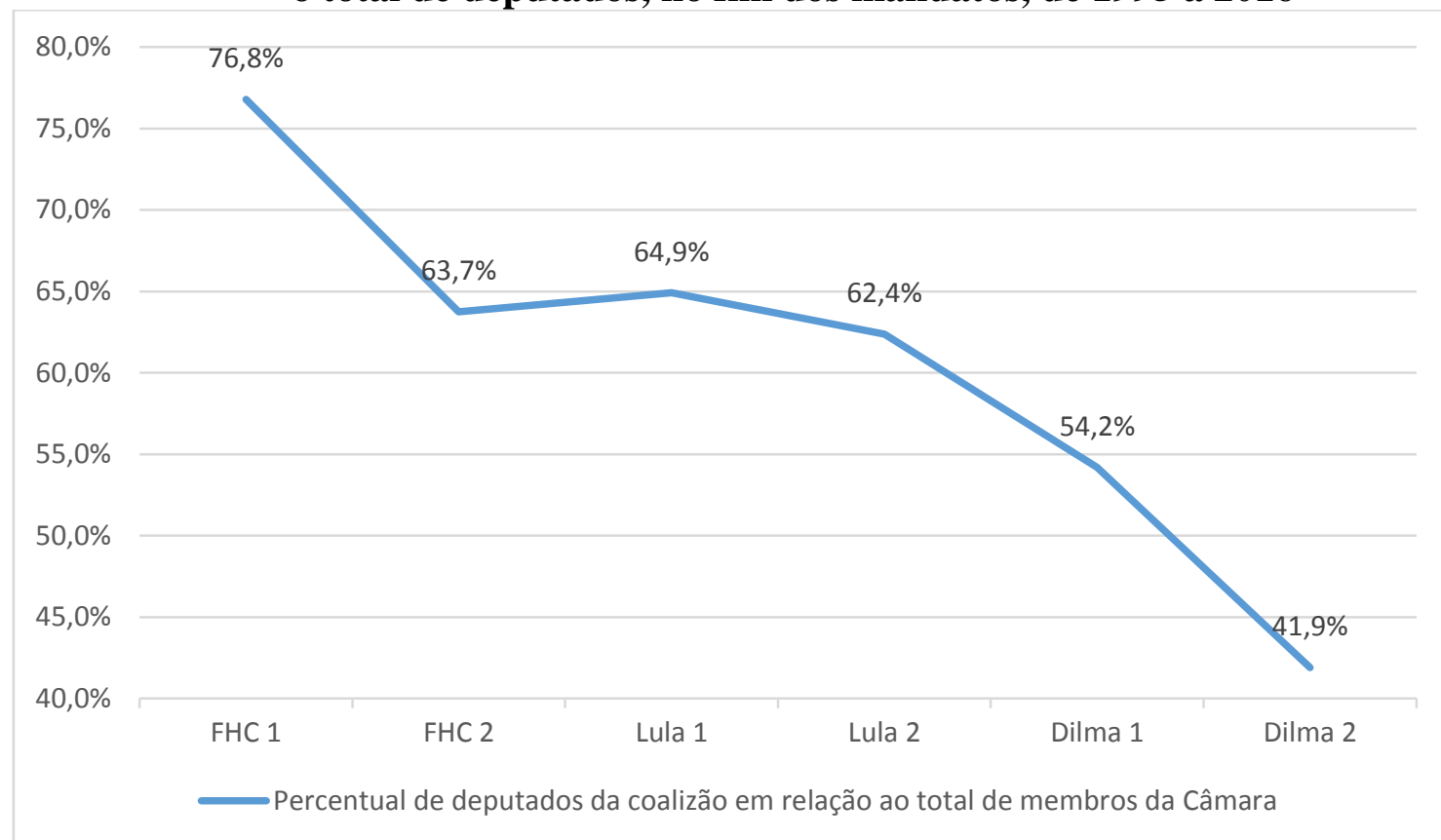

Fonte: Elaboração própria, a partir do Banco de Dados Legislativos do CEBRAP. Dados brutos recebidos em 11/11/2016.

Os números relativos ao fim dos mandatos merecem especial destaque por expressarem o nível de apoio que cada presidente conseguiu construir ao longo do seu governo. Nesse aspecto, é possível observar que os governos FHC e Lula concluíram seus dois mandatos com expressivo apoio parlamentar na Câmara dos Deputados, com condições de aprovar, inclusive, mudanças constitucionais, que requerem a votação favorável de 309 membros, ou seja, 3/5 dos parlamentares da Casa.

Dois fatos específicos chamam a atenção. Em primeiro legar, nota-se o aumento significativo da base no governo Lula 1, resultado da construção de novas alianças durante o mandato e da entrada do PMDB na coalizão, com todo o peso da sua bancada de 80 deputados. Além disso, vale ressaltar que, no fim do segundo mandato de Dilma, embora a base da presidenta fosse composta oficialmente por 215 deputados - o que significa, portanto, que 298 não integravam a coalizão -, 367 votaram favoravelmente ao impeachment, demonstrando que Dilma não obteve apoio dos considerados "governistas" num momento crucial.

O comportamento individual dos parlamentares nas votações diz muito sobre a coesão interna e a coerência das posições dos partidos políticos, inclusive quanto a seguir 
(ou não) as orientações do governo. Sendo assim, a disciplina partidária, ou seja, a atuação dos membros após a orientação dos líderes, é indicador fundamental para a mensuração do papel dos partidos na arena política.

Freitas (2013) analisa o comportamento dos partidos políticos, para verificar se atuam ou não como atores unitários. Segundo ela, a relação entre candidatos e eleitores influencia a interação entre parlamentares e partidos. A votação nos partidos favorece a disciplina partidária, enquanto a votação nos indivíduos a desestimula. Do mesmo modo, quanto maior for o controle dos líderes sobre a escolha dos candidatos, maior será sua capacidade de induzir a cooperação dos membros. Além disso, o grau de centralização de agenda e recursos nas mãos dos líderes também induz a busca de estratégias coletivas de ação.

A partir da sistematização de estudos sobre a disciplina partidária em outros países e do levantamento de dados sobre o fenômeno no Brasil de 1989 a 2011, a autora conclui que, mesmo nos sistemas presidencialistas, os partidos políticos operam a construção de consensos que lhes permita atuar como atores unitários nos momentos em que isso é necessário. Em sua pesquisa, ela observa que a correlação entre a concordância dos partidos com o governo na Câmara e no Senado é da ordem de 0,75 , o que, segundo ela, é explicado pela existência de um ator coletivo - os partidos políticos - organizando a atuação dos parlamentares (FREITAS, 2013).

O comportamento do Congresso espelha o conflito entre governo e oposição, ou seja, os votos dos parlamentares são o reflexo da sua posição em relação ao Executivo. Limongi (2006) identifica que a disciplina média da base do governo, isto é, a proporção de deputados da coalizão que votaram em acordo com a indicação expressa do líder do governo, é de 87,4\% no período que vai de 1988 a 2006, variando de 78,4\%, sob Sarney, e $90,7 \%$, no segundo mandato de FHC.

Segundo o autor, mais importante do que a magnitude da disciplina é a previsibilidade. Nesse aspecto, o presidente raramente é derrotado. No período analisado, o governo saiu vitorioso em 91,3\% das votações. Na maioria das derrotas, o problema não foi a indisciplina da base, mas sua cisão, quando um ou mais partidos não seguiram a orientação do líder do governo. De acordo com Figueiredo e Limongi (2007), foram as prerrogativas concedidas aos líderes partidários pela Constituição de 1988 que tornaram mais forte e consistente o apoio das coligações aos Presidentes, visto que esses novos 
poderes permitiram maior organização da dinâmica de interação entre o Executivo e sua base de apoio.

A partir daquele momento, houve um aumento importante das ferramentas e recursos parlamentares nas mãos dos líderes partidários. Se entre 1946 e 1964 eles só tinham competência para retirar projetos das comissões por meio de procedimentos de urgência, no pós-88, além da ampliação desse poder, as lideranças partidárias ganharam as prerrogativas de determinar a agenda do plenário, representar todos os seus membros no Parlamento, restringir emendas e votações em separado, nomear e substituir membros de comissões permanentes e de comissões permanentes que analisam medidas provisórias e orçamento (FIGUEIREDO; LIMONGI, 2007).

Para os objetivos deste trabalho, portanto, interessa medir a disciplina dos partidos - em especial, os integrantes da base - em relação ao governo. Para isso, são utilizados os dados da disciplina dos deputados federais em relação à indicação do líder do governo em cada votação nominal, levando-se em conta as votações não-unânimes e válidas. Uma votação é considerada unânime se i) todos os líderes dos partidos indicaram o mesmo voto, ou ii) pelo menos $90 \%$ dos deputados presentes à sessão votaram da mesma forma. Uma votação é considerada válida, por sua vez, se pelo menos $50 \%$ dos deputados estiveram presentes à votação.

O cálculo é feito levando em consideração todas as votações nominais em que houve a indicação do líder do governo, visto que não é em todos os casos que a liderança manifesta posicionamento. Em seguida, divide-se o total de votações em que o parlamentar votou de forma disciplinada pelo total de votações em que o líder indicou um posicionamento. Desse modo, o percentual de deputados disciplinados diz respeito àqueles que votaram de acordo com a indicação do líder do governo; o de indisciplinados, por sua vez, refere-se aos que votaram de maneira diferente da indicação do líder do governo. Os resultados estão indicados no gráfico abaixo: 
Gráfico 12 - Taxa de disciplina da coalizão, por mandato, de 1995 a 2016

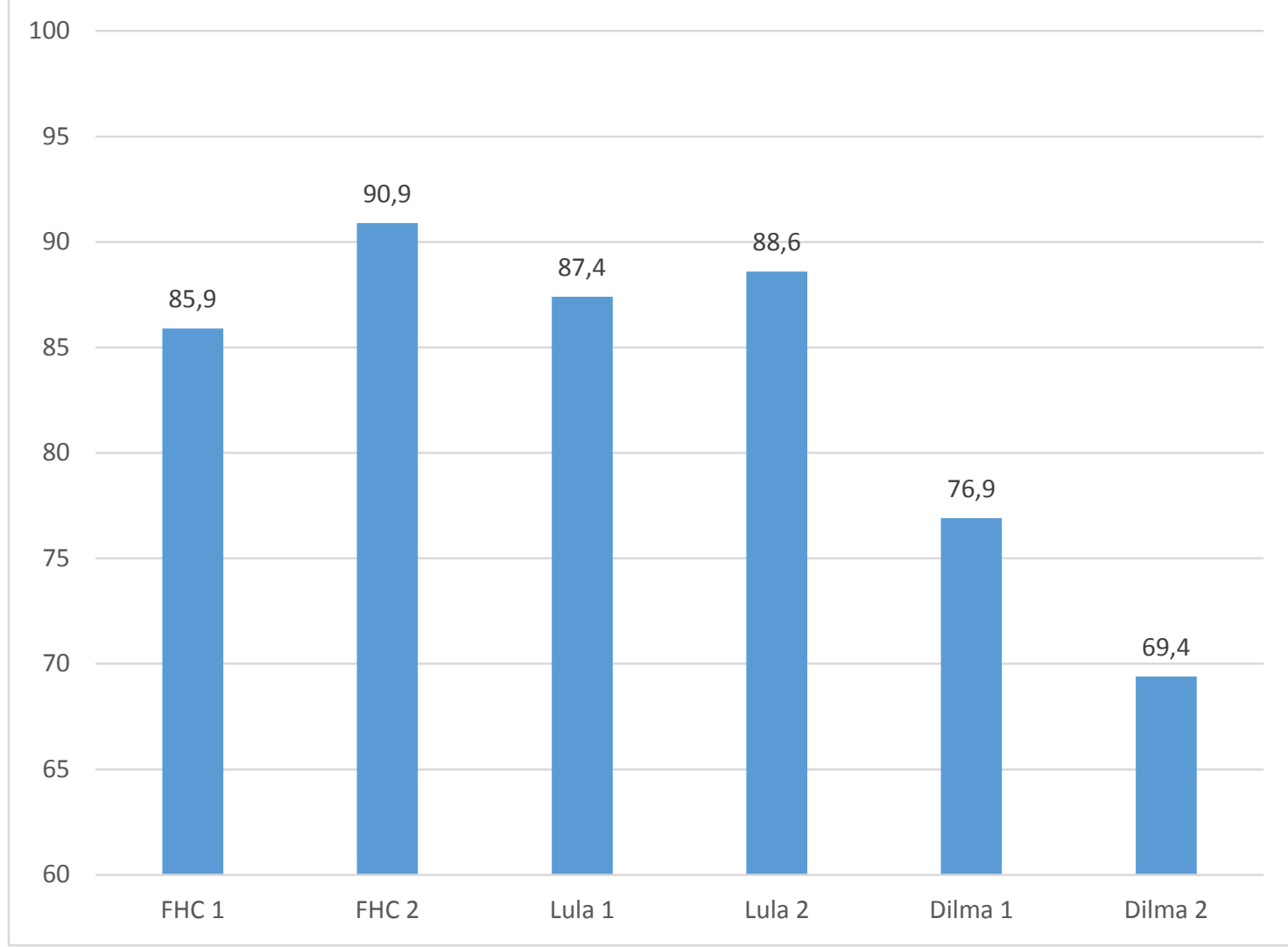

Fonte: Elaboração própria, a partir do Banco de Dados Legislativos do CEBRAP. Acesso em 23/11/2016.

Visualizando em outro formato, que evidencia melhor o comportamento dinâmico do fenômeno, a curva é a seguinte: 
Gráfico 13 - Taxa de disciplina da coalizão, por mandato, de 1995 a 2016

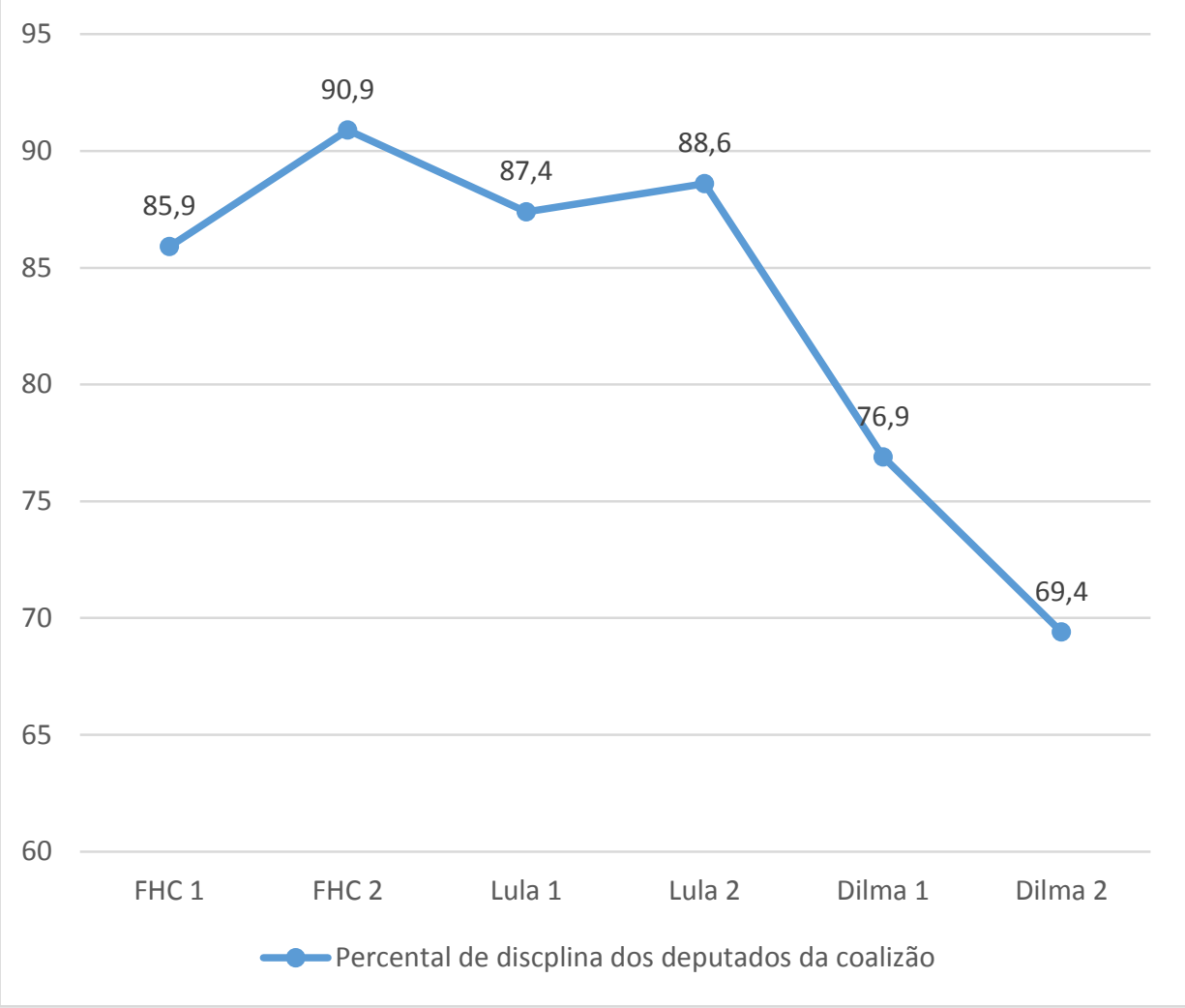
23/11/2016.

Fonte: Elaboração própria, a partir Banco de Dados Legislativos do CEBRAP. Acesso em

Cotejando-se agora a disciplina da coalizão com o seu tamanho no fim de cada mandato, tem-se a seguinte situação: 
Gráfico 14 - Número de deputados e taxa de disciplina da coalizão ao final de cada mandato, de 1995 a 2016

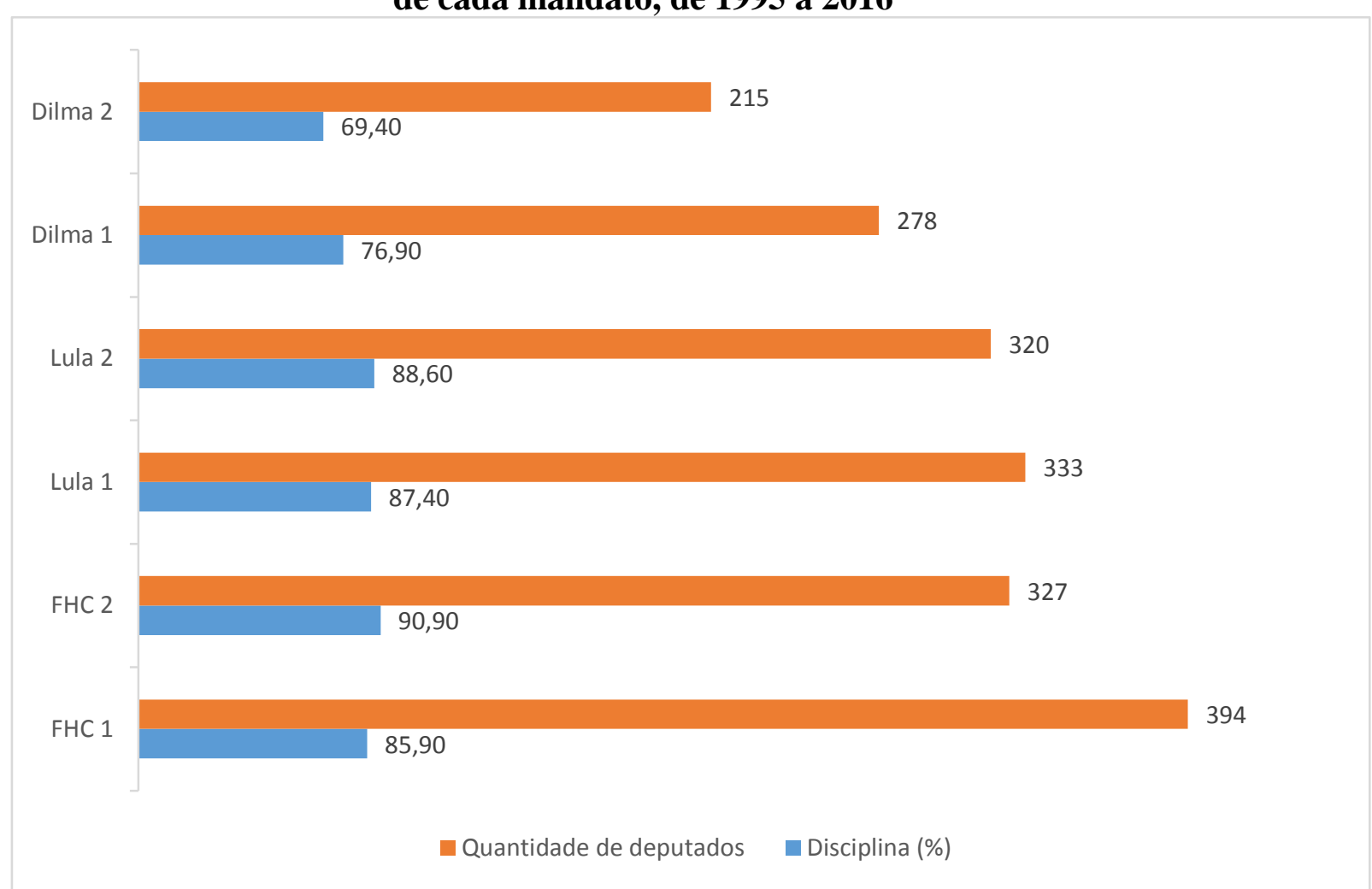

Fonte: Elaboração própria, a partir Banco de Dados Legislativos do CEBRAP. Dados sobre número de deputados recebidos em 11/11/2016 e acesso à base de dados sobre disciplina em 23/11/2016.

Os dados demonstram que Lula e FHC, em seus dois mandatos, apresentaram valores semelhantes para os dois indicadores relativos à coalizão, excluído aí o tamanho notadamente "fora da curva" da base no fim do primeiro governo de FHC. Entretanto, nos dois governos Dilma, há uma redução acentuada na disciplina e na quantidade de deputados da coalizão, chegando, no fim do seu segundo mandato, aos valores de 69,4 e 215 , respectivamente.

\subsection{Grau de coalescência}

Nos sistemas presidencialistas, o presidente tem discricionariedade para distribuir os Ministérios, podendo convidar ou não outros partidos para compor o governo, ou nomear ministros sem envolvimento partidário (FIGUEIREDO, 2006). O que se espera é que, quanto maior a proporcionalidade na composição do gabinete, mais disciplinado é o comportamento legislativo dos partidos da coalizão (AMORIM NETO, 2000). 
Essa proporcionalidade entre os ministérios designado aos partidos e as cadeiras ocupadas por cada um no Congresso é denominada "taxa de coalescência". Tal indicador revela o nível de sustentação política da formação ministerial. Em 2003, por exemplo, embora Lula tenha distribuído muitos ministérios ao Partido dos Trabalhadores (PT) em detrimento do resto da coalizão, a proporcionalidade global entre as pastas e as cadeiras parlamentares foi bem elevada $(0,64)$. Isso porque, naquele momento, a base governista era composta por pequenos partidos, de modo que a atribuição de apenas uma carteira para cada foi suficiente para garantir uma alocação proporcional. No entanto, após o episódio do mensalão, a coalescência diminuiu, pois o PMDB (Partido do Movimento Democrático Brasileiro) entrou coalizão, mas levou apenas dois Ministérios, apesar do seu peso no Congresso (AMORIM NETO, 2012).

Os gabinetes presidenciais, no início e no fim dos mandatos, apresentaram a seguinte composição:

Tabela 4 - Composição partidária dos gabinetes, no início e fim dos mandatos, de 1995 a 2016

\begin{tabular}{|c|c|c|}
\hline Mandato & Período & Partidos representados no gabinete \\
\hline \multirow{2}{*}{ FHC 1 } & Início & PSDB-PMDB-PFL-PTB \\
\cline { 2 - 3 } & Fim & PSDB-PMDB-PFL-PTB-PPB-PPS \\
\hline \multirow{2}{*}{ FHC 2 } & Início & PSDB-PMDB-PFL-PTB-PPB-PPS \\
\cline { 2 - 3 } & Fim & PSDB-PMDB-PPB \\
\hline \multirow{2}{*}{ Lula 1 } & Início & PT-PSB-PDT-PPS-PCdoB-PV-PL-PTB \\
\cline { 2 - 3 } & Fim & PT-PSB-PCdoB-PV-PTB-PMDB-PP \\
\hline \multirow{2}{*}{ Lula 2 } & Início & PT-PTB-PMDB-PV-PSB-PP-PCdoB \\
\cline { 2 - 3 } & Fim & PT-PMDB-PV-PSB-PP-PCdoB \\
\hline \multirow{2}{*}{ Dilma 1 } & Início & PT-PMDB-PSB-PR-PP-PDT-PCdoB \\
\cline { 2 - 3 } & Fim & PT-PMDB-PSD-PR-PP-PDT-PCdoB-PRB \\
\hline \multirow{2}{*}{ Dilma 2 } & Início & PT-PMDB-PSD-PR-PP-PDT-PCdoB-PRB-PTB-PROS \\
\cline { 2 - 3 } & Fim & PT-PP-PR-PDT-PCdoB-PTB \\
\hline
\end{tabular}

Fonte: Elaboração própria, a partir de Amorim (2012) e do Banco de Dados Legislativos do CEBRAP.

Outro dado interessante diz respeito ao percentual de ministros apartidários nomeados por cada presidente: 
Gráfico 15 - Percentual de ministros sem filiação partidária, no início e no fim dos mandatos, de 1995 a 2016

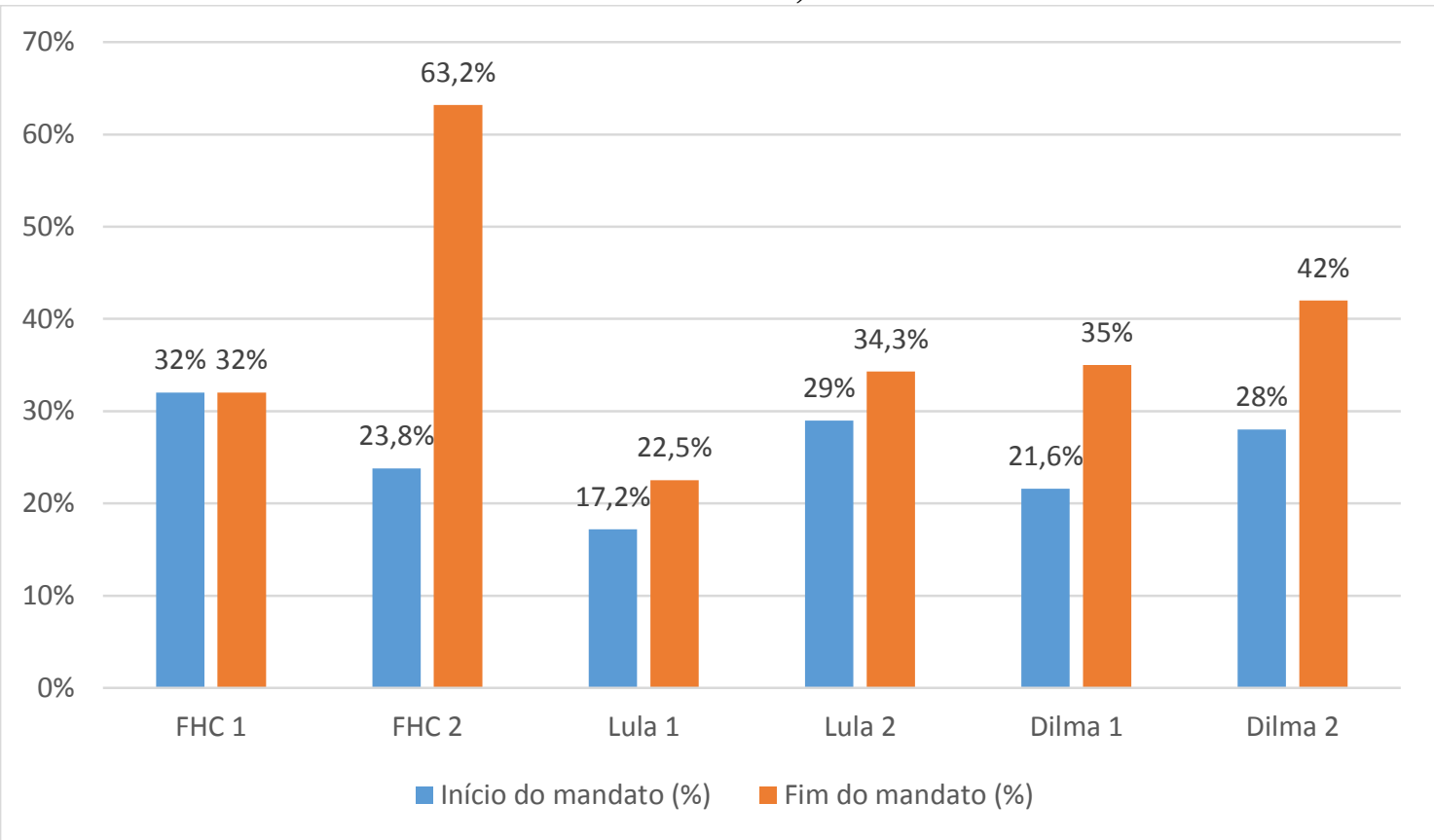
CEBRAP.

Fonte: Elaboração própria, a partir de Amorim (2012) e da Base de Dados Legislativos do

No caso dos três presidentes, o fim dos seus segundos mandatos foi o período com o maior percentual de ministros sem filiação partidária. Provavelmente, isso se deve ao fato de não haver mais necessidade de construção de apoio parlamentar, por não ser mais possível a reeleição, o que lhes confere maior liberdade.

FHC, no fim do seu segundo governo, apresenta alto percentual de ministros sem filiação partidária $(63,2 \%)$, contrastando enormemente com o valor no início desse mandato (23,8\%). Em seguida, vem Dilma 2, que fechou o governo com mais de $40 \%$ de ministros sem partido. O mandato de Lula 1 foi o que se iniciou com o menor percentual de Pastas chefiadas por quadros sem filiação partidária (17,2\%), seguido por Dilma 1 $(21,6 \%)$.

Calculando-se, finalmente, a taxa de coalescência no início e no fim de cada mandato, tem-se o seguinte quadro: 
Gráfico 16 - Taxa de coalescência, por mandato, de 1995 a 2016

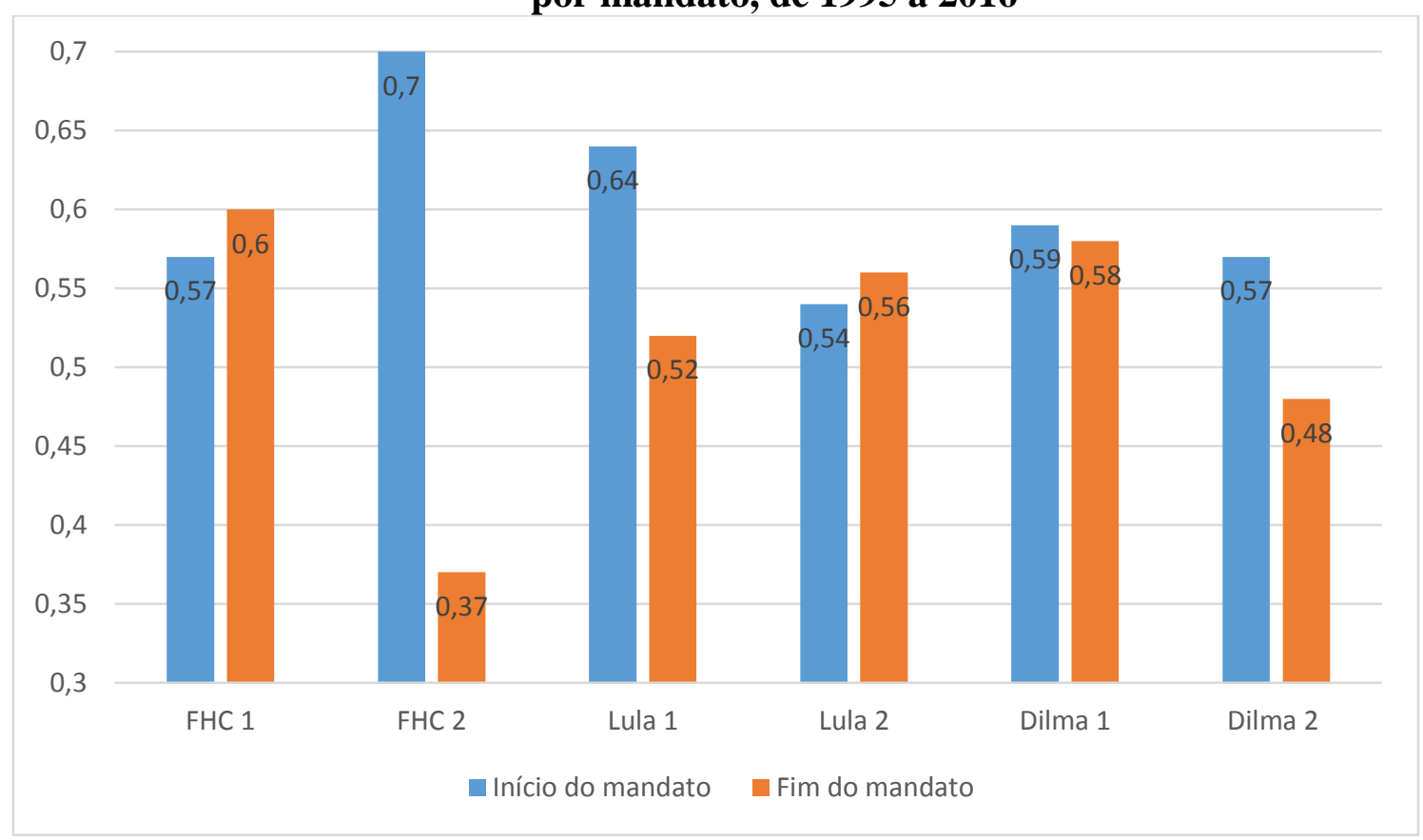

Fonte: Elaboração própria, a partir de Amorim (2012) e da Base de Dados Legislativos do CEBRAP.

Mais uma vez, FHC, no seu segundo mandato, apresenta taxa bem destoante dos demais governos, iniciando com alta proporcionalidade $(0,7)$ e fechando o governo com a metade do valor $(0,37)$. Lula 1 também inicia o mandato com taxa expressiva $(0,64)$, com um gesto de muita atenção à coalizão. O segundo menor valor de fechamento de mandato pode ser observado em Dilma $2(0,48)$, indicando um gabinete que pouco espelhava o apoio que, em tese, o governo ainda teria na reta final pré-impeachment.

\subsection{Rotatividade de ministros}

A frequência de trocas de ministros pode ser entendida como indicativo do nível de instabilidade do governo. Para o andamento dos projetos, é importante que a direção ministerial sofra o mínimo de alterações possível. Se o presidente se vê diante da necessidade de fazer mudanças e, especialmente, se isso ocorre com frequência, tal fato costuma ser sinal de inconstância na composição da base ou dificuldade do governo em "segurar" seus ministros, que podem ter tido que entregar os cargos em decorrência de alguma crise. 
Para melhor observação do fenômeno, verificou-se a frequência de troca de ministros por mandato. Foram excluídos os ministros interinos, que exercem função "tampão" até que se nomeie o titular. No caso de Dilma 2, como a presidenta foi afastada antes do término do seu mandato, os cálculos foram feitos de duas formas: i) dividindose o tempo total de ocupação dos cargos pelo número de trocas, tal como foi feito para os mandatos de todos os outros presidentes; e ii) desconsiderando-se os ministros que saíram na data do afastamento, descartando-se também os seus respectivos períodos de permanência no cargo, para que os resultados não fossem contaminados por esse fato. $\mathrm{Ou}$ seja, foram mantidos apenas os dados referentes aos ministros não exonerados em função da saída da presidenta. A consolidação dos dados brutos está sintetizada na tabela abaixo:

Tabela 5 - Tempo médio de permanência dos ministros titulares, por mandato, de 1995 a 2016

\begin{tabular}{|c|c|c|}
\hline Presidente & $\begin{array}{c}\text { Número de trocas } \\
\text { de ministros }\end{array}$ & $\begin{array}{c}\text { Média de } \\
\text { permanência (dias) }\end{array}$ \\
\hline FHC 1 & 63 & 650,67 \\
\hline FHC 2 & 79 & 484,11 \\
\hline Lula 1 & 77 & 719,78 \\
\hline Lula 2 & 73 & 684,79 \\
\hline Dilma 1 & 82 & 692,04 \\
\hline Dilma 2 & 72 & 242,71 \\
\hline Dilma 2* & 40 & 257,85 \\
\hline
\end{tabular}

* Estão excluídos os dados referentes aos Ministros que saíram com Dilma na data do seu afastamento.

Fonte: Elaboração própria, a partir do Banco de Dados Legislativos do CEBRAP. Dados brutos recebidos em 10/11/2016.

Visualizando em formato gráfico, tem-se a seguinte figura: 


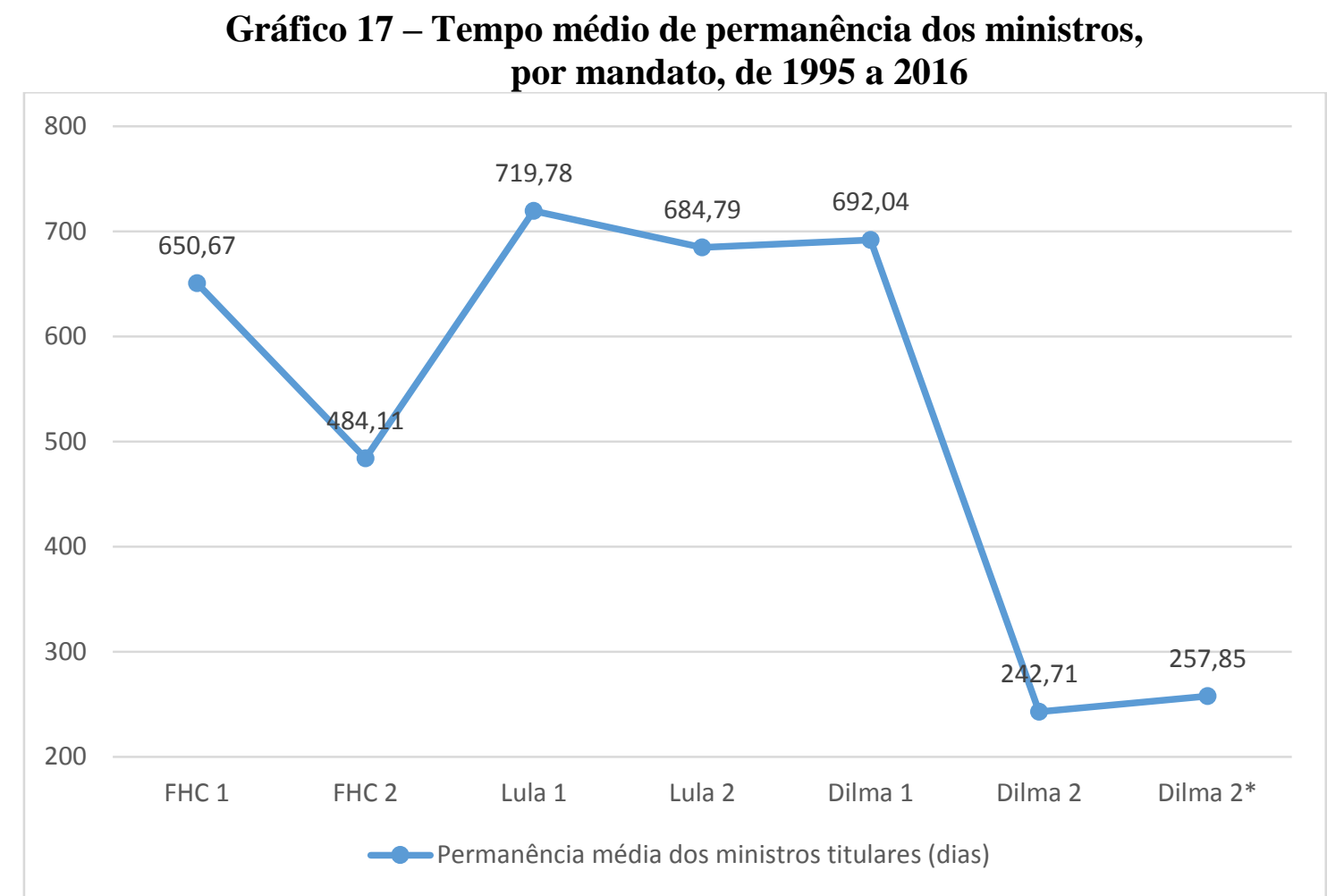

* Estão excluídos os dados referentes aos Ministros que saíram com Dilma na data do seu afastamento.

Fonte: Elaboração própria, a partir do Banco de Dados Legislativos do CEBRAP. Dados brutos recebidos em 10/11/2016.

Outro dado importante para a medição do nível de estabilidade do governo é a rotatividade dos ministros responsáveis pela articulação com o Congresso. No decorrer dos seus mandatos, os chefes do Executivo alteram a estrutura ministerial, criando, extinguindo e fundindo Pastas, e redefinem papéis em suas equipes. Esse fenômeno tende a ser mais comum nos órgãos de assessoramento direto ao presidente, integrantes da Presidência da República. Desse modo, a função de administrar a relação com o Legislativo é desempenhada por diferentes atores ao longo dos governos. O quadro abaixo traz os nomes e as quantidades de ministros responsáveis por esse papel em cada mandato, com o cálculo do seu tempo médio de permanência no cargo: 
Tabela 6 - Ministros responsáveis pela articulação com o Congresso, por mandato, de 1995 a 2016

\begin{tabular}{|c|c|c|}
\hline Mandato & Ministros & $\begin{array}{l}\text { Quantidade e } \\
\text { tempo médio }\end{array}$ \\
\hline FHC 1 & $\begin{array}{l}\text { 1. Eduardo Jorge - Secretaria-Geral (1995) } \\
\text { 2. Luiz Carlos Santos - Ministério Extraordinário para a } \\
\text { Coordenação de Assuntos Políticos (1996) } \\
\text { 3. Eduardo Graeff - Secretaria-Geral (1998) }\end{array}$ & $\begin{array}{l}3 \text { Ministros } \\
486 \text { dias }\end{array}$ \\
\hline FHC 2 & $\begin{array}{l}\text { 1. Eduardo Graeff - Secretaria de Relações Institucionais (1999) } \\
\text { 2. Aloysio Nunes Ferreira - Secretaria-Geral (1999) }\end{array}$ & $\begin{array}{l}2 \text { Ministros } \\
730 \text { dias }\end{array}$ \\
\hline Lula 1 & $\begin{array}{l}\text { 1. José Dirceu - Casa Civil (2003) } \\
\text { 2. Aldo Rebelo - Secretaria de Relações Institucionais (2004) } \\
\text { 3. Jacques Wagner - Secretaria de Relações Institucionais (2005) }\end{array}$ & $\begin{array}{l}3 \text { Ministros } \\
486 \text { dias }\end{array}$ \\
\hline Lula 2 & $\begin{array}{l}\text { 1. Tarso Genro - Secretaria de Relações Institucionais (2006) } \\
\text { 2. Walfrido Mares Guias - Secretaria de Relações - Institucionais } \\
\text { (2007) } \\
\text { 3. José Múcio - Secretaria de Relações Institucionais (2007) } \\
\text { Alexandre Padilha- Secretaria de Relações Institucionais (2009) }\end{array}$ & $\begin{array}{l}3 \text { Ministros } \\
486 \text { dias }\end{array}$ \\
\hline Dilma 1 & $\begin{array}{l}\text { 1. Antônio Palocci - Casa Civil (2011) } \\
\text { 2. Luiz Sérgio Oliveira - Secretaria de Relações Institucionais } \\
\text { (2011) } \\
\text { 3. Ideli Salvatti - Secretaria de Relações Institucionais (2011) }\end{array}$ & $\begin{array}{l}3 \text { Ministros } \\
486 \text { dias }\end{array}$ \\
\hline Dilma 2 & $\begin{array}{l}\text { 1. Pepe Vargas - Secretaria de Relações Institucionais (2015) } \\
\text { 2. Michel Temer - Secretaria de Relações Institucionais (2015) } \\
\text { 3. Ricardo Berzoini - Secretaria de Governo (2015) / Jaques } \\
\text { Wagner - Casa Civil (2015) } \\
\text { 4. Lula* - Casa Civil (2016) / Jaques Wagner - Gabinete da PR } \\
\text { (2016) } \\
\text { *não chegou a assumir }\end{array}$ & $\begin{array}{l}\quad 4 * \text { Ministros } \\
\quad 124 \text { dias } \\
\text { *Considerando } \\
\text { Lula, que não } \\
\text { assumiu, } \\
\text { permanecendo vago } \\
\text { o posto de ministro } \\
\text { da Casa Civil. A } \\
\text { articulação política } \\
\text { continuou também } \\
\text { sendo feita por } \\
\text { Jaques Wagner, ex- } \\
\text { ministro da Casa } \\
\text { Civil, que foi } \\
\text { deslocado para o } \\
\text { Gabinete da PR. }\end{array}$ \\
\hline
\end{tabular}

Fonte: Elaboração própria, a partir do estudo de Lameiro (2014) e do Banco de Dados Legislativos do CEBRAP

Durante os mandatos FHC 1, Lula 1 e 2 e Dilma 1, os presidentes tiveram três ministros responsáveis pela articulação com o Congresso. Em seu segundo governo, FHC realizou apenas uma troca, totalizando dois nomes. A maior rotatividade ocorreu no segundo mandato de Dilma, que teve 4 ministros em pouco mais de 17 meses de governo, sem contar Jaques Wagner, que também geria a relação com o Executivo, pela Casa Civil, embora a competência institucional fosse da Secretaria de Governo, chefiada por Ricardo Berzoini. 


\subsection{Fragmentação partidária}

A negociação com o Legislativo torna-se mais difícil com a multiplicidade de partidos, podendo levar, no limite, à paralisia decisória. Isso decorre, em grande medida, do sistema proporcional, que tende a aumentar a polarização ideológica. Ainda que a fragmentação partidária por si só não conduza à ingovernabilidade, ela significa, no mínimo, maior custo de negociação, uma vez que o Executivo terá um maior número de frentes para a construção de acordos, aumentando, portanto, o custo de transação relacionado a isso.

Para a análise da fragmentação partidária, não basta contar o número de partidos, pois não seria razoável considerar que um partido com menos de 10 parlamentares tenha o mesmo peso, dentro do Congresso, que um partido com mais de 80 parlamentares, por exemplo.

Douglas Rae (1967) criou um índice para mensurar o grau de dispersão de votos para qualquer eleição. Assim, quanto mais próximo de 1, mais fragmentado um sistema, e quanto mais próximo de 0 , mais concentrado. A tabela abaixo indica o grau de fracionalização da Câmara dos Deputados no Brasil:

Tabela 7 - Taxa de fracionalização da Câmara dos Deputados, por mandato, de 1982 a 2006

\begin{tabular}{|c|c|}
\hline Ano & Taxa de fracionalização \\
\hline 1982 & 0,59 \\
\hline 1986 & 0,65 \\
\hline 1990 & 0,89 \\
\hline 1994 & 0,88 \\
\hline 1998 & 0,86 \\
\hline 2002 & 0,88 \\
\hline 2006 & 0,89 \\
\hline
\end{tabular}

Fonte: LEEX, http://www.ucam.edu.br/leex/Brasil/Compet/ELEIAL.htm,

Marku Laakso e Rein Taagepera (1979) criaram outro índice, que leva em conta o número de partidos e o grau de sua relevância (Nicolau, 2004), denominado " índice do número efetivo de partidos políticos" (NEP), calculado por meio da fórmula $1 /\left(\sum \mathrm{pi}^{2}\right)$, onde $\mathrm{pi}=$ percentual de cadeiras ocupadas por cada partido. 
Comparando a Câmara dos Deputados brasileira, o Brasil desponta como um dos maiores caso de fragmentação partidária legislativa no mundo. Pippa Norris (2008) identifica que, no ano 2000, a média de partidos efetivos em 138 países é 4,1. Durante a década de 90, a média na América Latina foi de 3,6 (Alcántra Sáez e Freidenberg, 2002). No Brasil, a média do número efetivo de partidos parlamentares na Câmara dos Deputados, entre 1990 a 2010, é de 8,8.

Realizando os cálculos para a situação da Câmara dos Deputados no início de cada um dos mandatos, tem-se o seguinte quadro:

\section{Gráfico 18 - Número efetivo de partidos políticos, por mandato, de 1995 a 2016}

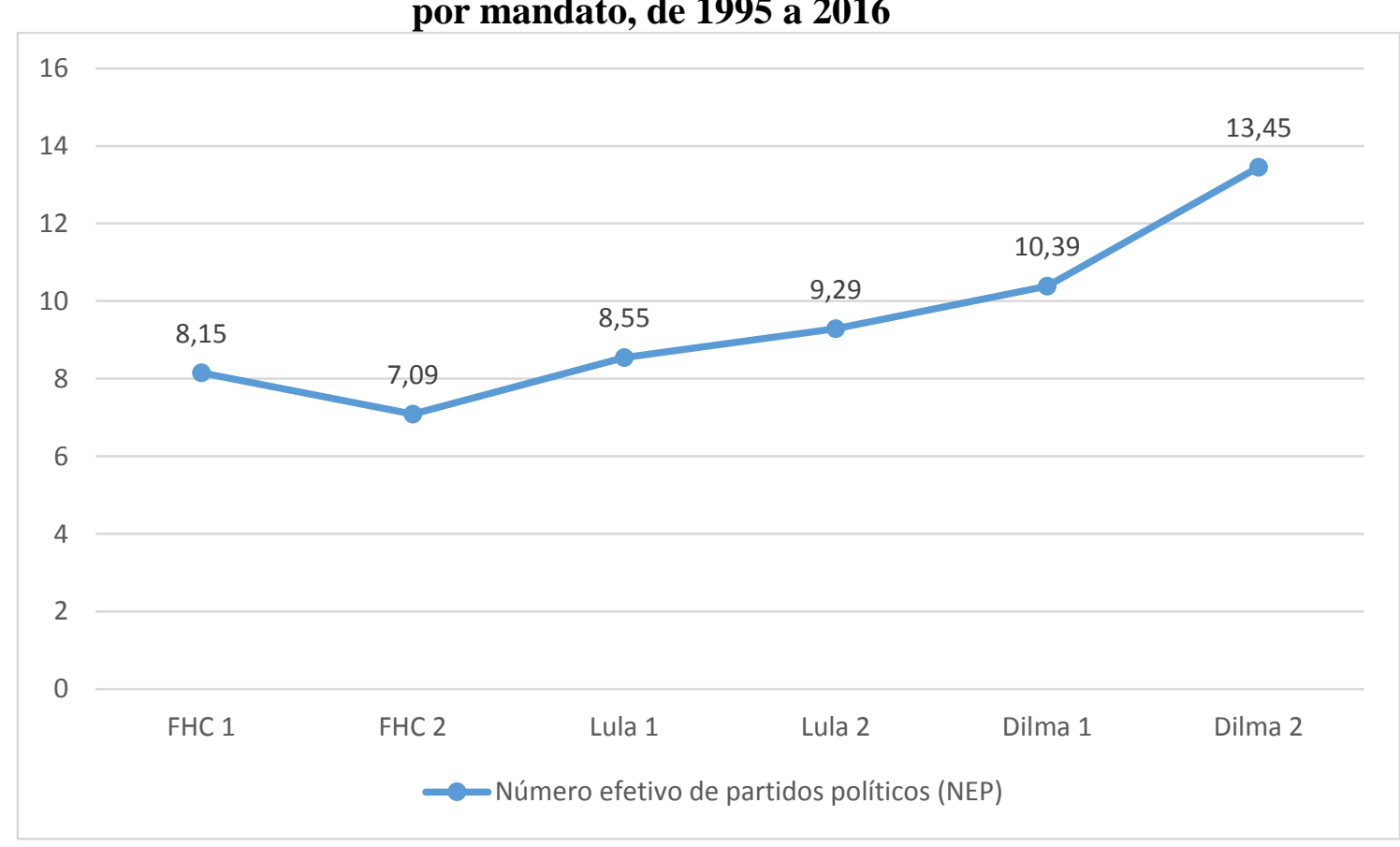

Fonte: Elaboração própria, a partir do Banco de Dados Legislativos do CEBRAP

Outra maneira de visualizar a fragmentação poderia ser a contagem das cadeiras ocupadas por partidos com números muito baixos de parlamentares. Considerando, por exemplo, partidos com menos de dez deputados na Câmara, tem-se a seguinte situação: 


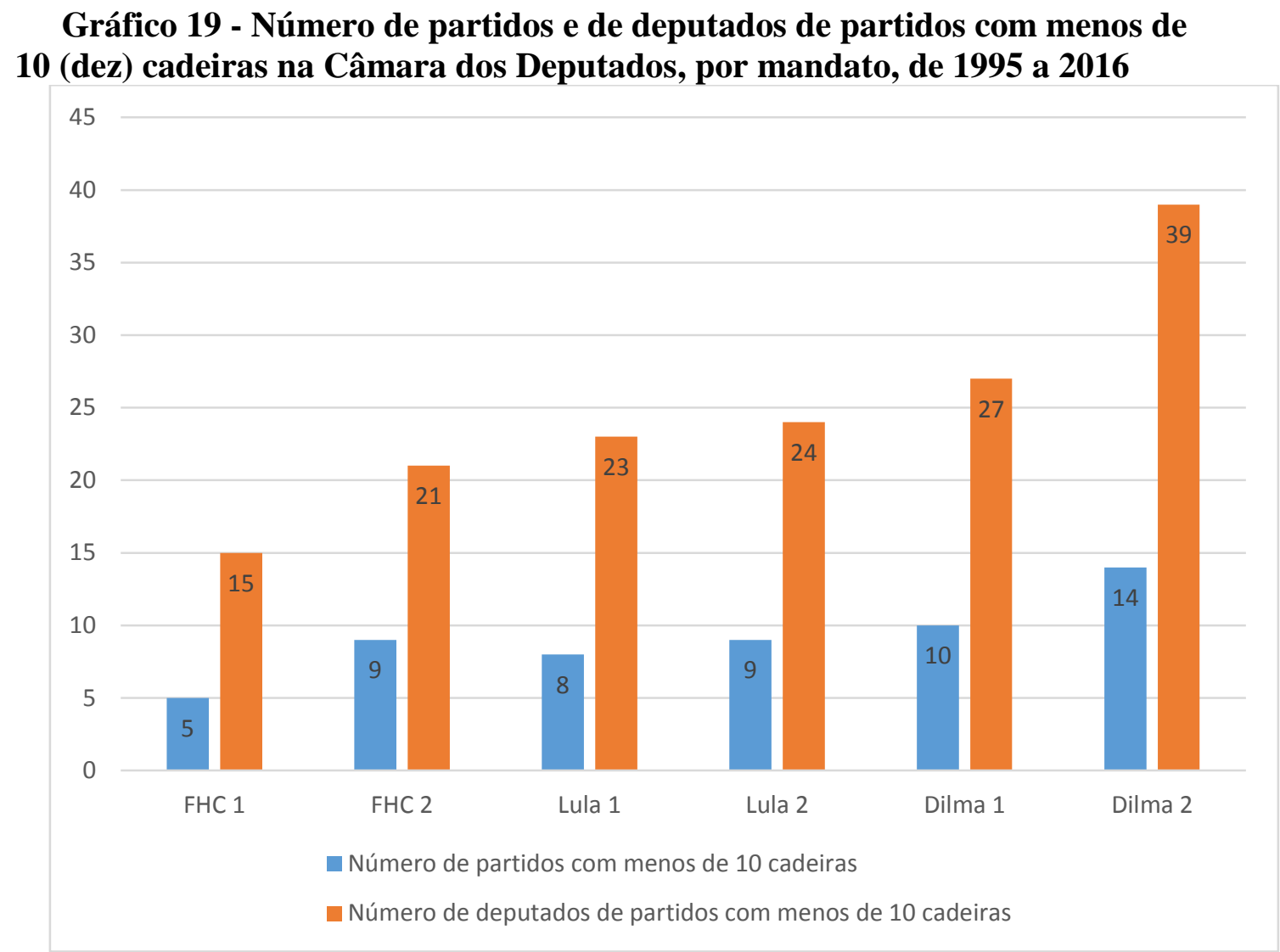

Fonte: Elaboração própria, a partir do Banco de Dados do CEBRAP

Nos dois gráficos, observa-se clara tendência ao aumento da fragmentação a cada mandato. O número efetivo de partidos políticos (NEP) é menor em FHC 2, chegando a 7,09, e é relativamente parecido, embora crescente, em FHC 1 e Lula 1 e 2, oscilando entre 8,15 e 9,29. No primeiro mandato de Dilma, o índice é superior a 10, superando o valor de 13 em seu segundo mandato.

Em relação aos partidos com menos de dez deputados na Câmara, os valores são mais baixos em FHC 1 (5 partidos e 15 parlamentares), e seguem uma tendência crescente a partir de então, chegando a 10 e 27, respectivamente, em Dilma 1. No segundo governo Dilma, os números totalizam 14 partidos e 39 parlamentares.

Nota-se, portanto, aumento crescente da fragmentação, em especial nos mandatos de Dilma, com números expressivos no seu segundo governo. Isso significa que a presidenta teve que lidar com um Congresso ainda mais pulverizado que os seus antecessores, o que implica naturalmente maiores custos de negociação e de gestão da relação com o Legislativo. 
É importante que se faça uma ressalva fundamental: embora a fragmentação partidária seja um fator que dificulta a negociação com o Congresso, ela não está sob o controle do governo. Isso equivale dizer que se trata de uma situação dada, resultante das eleições, com a qual o Executivo tem que lidar, aumentando a necessidade de habilidade política para enfrentá-la.

\subsection{Aprovação do orçamento impositivo}

Para sustentarem coalizões majoritárias no Congresso e terem condições políticas de governar, os presidentes costumam fazer uso de um instrumento fundamental de negociação com o Parlamento - as emendas parlamentares. Isso ocorre não apenas no Brasil, mas em outros presidencialismos multipartidários, onde o Executivo executa discricionariamente as iniciativas legislativas ao orçamento.

No Brasil, a partir da sanção da Lei de Diretrizes Orçamentárias de 2014 e da posterior promulgação da Emenda Constitucional $n^{\circ}$ 86, de 2015, a regra foi alterada pelo Congresso, tornando obrigatória a execução das programações orçamentárias derivadas de emendas individuais, por meio da aprovação do denominado orçamento impositivo. Isso significou o fim da liberdade decisória do Executivo e, portanto, do seu poder de barganha com o Parlamento. A nova regra, em síntese, significa que a execução da lei orçamentária, em relação às programações incluídas ou acrescidas por meio de emenda individual, tornou-se um dever do gestor, salvo em casos de impedimentos técnicos ou legais.

Além de aumentar a participação do Congresso na definição de políticas públicas, o governo sabia, desde sempre, que haveria fortes impactos no sistema político em termos de governabilidade, estabilidade e previsibilidade. O custo do apoio deveria aumentar, pois os parlamentares passariam a internalizar os ganhos eleitorais decorrentes da execução impositiva de suas emendas independentemente do apoio político ao presidente, e novos recursos seriam demandados para a construção e manutenção de maiorias legislativas (RENNÓ; PEREIRA FILHO, 2013).

Para Greggiani e Silva (2015, p. 6), a mudança da regra foi resultado do descontentamento dos parlamentares com os baixos níveis de execução das emendas individuais, conforme demonstrou uma pesquisa realizada em 2013 com chefes de gabinetes de deputados. Nesse estudo, dois terços deles confirmaram ter havido aumento 
na dificuldade de liberação dessas emendas, um indicativo da insatisfação política (GREGGIANIN, 2013).

A Emenda Constitucional foi aprovada com ampla margem no dia 10 de fevereiro de 2015, em segundo turno, por 452 votos a favor e 18 contrários, com apenas uma abstenção (GREGGIANIN; SILVA, 2015). Por ser relativamente recente, talvez ainda seja cedo para avaliar os efeitos da medida. No entanto, para os objetivos deste trabalho, o ponto central em relação ao orçamento impositivo é destacar a fragilidade do governo e de sua base naquele momento, que não conseguiu impedir a aprovação de proposta com tamanho potencial ofensivo aos seus interesses. 


\subsection{Resultado do hemograma}

A partir dos processamentos de dados e das construções analíticas realizadas na seção anterior, chega-se ao seguinte "resultado do hemograma da governabilidade dos governos FHC, Lula e Dilma", que consiste no achado de pesquisa central deste trabalho:

Tabela 8 - Resultado do hemograma da governabilidade

\begin{tabular}{|c|c|c|c|c|c|}
\hline DIMENSÕES & INDICADORES & $\begin{array}{l}\downarrow \text { Governabi- } \\
\quad \text { lidade }\end{array}$ & $1^{\circ}$ lugar & $2^{\circ}$ lugar & $3^{\circ}$ lugar \\
\hline \multirow{3}{*}{$\begin{array}{l}\text { Produção e } \\
\text { aprovação de } \\
\text { projetos de lei }\end{array}$} & Taxa de participação & Depende* & Dilma 2 & FHC 1 & Dilma 1 \\
\hline & Taxa de sucesso & $\downarrow$ & Dilma 2 & Dilma 1 & Lula 2 \\
\hline & Taxa de dominância & $\downarrow$ & Lula 2 & Dilma 2 & Dilma 1 \\
\hline Vetos presidenciais & Percentual de projetos vetados & $\uparrow$ & Dilma 2 & Dilma 1 & Lula 2 \\
\hline $\begin{array}{c}\text { Aprovação de } \\
\text { Medidas Provisórias }\end{array}$ & $\begin{array}{l}\text { Taxa de conflito em Medidas } \\
\text { Provisórias }\end{array}$ & $\uparrow$ & Dilma 2 & Dilma 1 & Lula 2 \\
\hline \multirow{2}{*}{$\begin{array}{l}\text { Características da } \\
\text { coalizão }\end{array}$} & $\begin{array}{l}\text { Tamanho proporcional da } \\
\text { coalizão }\end{array}$ & $\downarrow$ & Dilma 2 & Dilma 1 & Lula 2 \\
\hline & Disciplina da coalizão & $\downarrow$ & Dilma 2 & Dilma 1 & FHC 1 \\
\hline Grau de coalescência & Taxa de coalescência & $\downarrow$ & FHC 2 & Dilma 2 & Lula 1 \\
\hline \multirow[b]{2}{*}{$\begin{array}{l}\text { Rotatividade de } \\
\text { ministros }\end{array}$} & Geral & $\uparrow$ & Dilma 2 & FHC 2 & Lula 2 \\
\hline & Articuladores com o Congresso & $\uparrow$ & Dilma 2 & $\begin{array}{l}\text { Dilma } 1 \\
\text { Lula } 2 \\
\text { Lula } 1 \\
\text { FHC } 1 \\
\end{array}$ & FHC 2 \\
\hline \multirow{2}{*}{$\begin{array}{l}\text { Fragmentação } \\
\text { partidária }\end{array}$} & $\begin{array}{l}\text { Número efetivo de partidos } \\
\text { políticos (NEP) }\end{array}$ & $\uparrow$ & Dilma 2 & Dilma 1 & Lula 2 \\
\hline & $\begin{array}{l}\text { Número de partidos com } \\
\text { menos de dez cadeiras na } \\
\text { Câmara }\end{array}$ & $\uparrow$ & Dilma 2 & Dilma 1 & Lula 2 \\
\hline $\begin{array}{l}\text { Aprovação do } \\
\text { orçamento } \\
\text { impositivo }\end{array}$ & $\begin{array}{l}\text { Momento em que houve a } \\
\text { mudança de regra }\end{array}$ & \multicolumn{4}{|c|}{$\begin{array}{l}\text { Dilma } 1 \text { (2013): aprovação da Lei de Diretrizes } \\
\text { Orçamentárias } 2014 \\
\text { Dilma } 2 \text { (2015): aprovação da Emenda } \\
\text { Constitucional no } 86 / 2015\end{array}$} \\
\hline
\end{tabular}

*Conforme abordado na seção anterior, é necessário cotejar o indicador com outros fatores para uma avaliação adequada da sua relação com a governabilidade. No caso analisado, desde o início de Dilma 1, a taxa de participação aumentou, enquanto a de sucesso diminuiu, o que indica dificuldade na relação com o Congresso, como já analisado anteriormente.

Fonte: Elaboração própria.

Além das 8 (oito) dimensões e dos 13 (treze) indicadores, o quadro traz o ranking dos governos quanto ao fenômeno governabilidade. Este "placar", elaborado a partir dos resultados calculados na seção anterior, leva em conta os 6 (seis) mandatos presidenciais entre 1995 e 2016 - FHC 1, FHC 2, Lula 1, Lula 2, Dilma 1 e Dilma 2 -, destacando os 3 (três) com menor nível de governabilidade em relação a cada indicador. Ou seja, em primeiro lugar sempre está o governo com menor grau de governabilidade em função de 
determinado indicador; na segunda posição, encontra-se o mandato com o segundo menor valor; e, em terceiro, o governo com o terceiro menor nível.

O hemograma revela interessante variação no padrão de governabilidade na comparação entre os mandatos presidenciais. O nível de coordenação entre os Poderes e, portanto, a capacidade governativa do Executivo, não é constante, o que indica que o presidencialismo de coalizão não se "comporta" da mesma forma em todas as gestões.

De acordo com o resultado, dos 13 (treze) indicadores analisados, 11 (onze) demonstram pior comportamento no governo Dilma 2 - período de acirramento da crise política -, dos quais 9 (nove) têm também o segundo pior resultado em Dilma 1. Quanto aos outros 2 (dois) indicadores, embora os primeiros colocados sejam mandatos diferentes dos de Dilma, o segundo pior resultado é observado no seu governo. Desse modo, o exame indica que, a partir de 2014, a relação entre Executivo e Congresso esteve mais comprometida do que nos mandatos anteriores.

Deve-se ressaltar que, durante todo o período estudado, as instituições capitais do presidencialismo de coalizão - a pista - permaneceram as mesmas. Do mesmo modo, todos os presidentes gozaram de semelhantes prerrogativas legais e tiveram ao seu dispor iguais instrumentos de coordenação - o carro. No entanto, o hemograma diagnostica distintos paradigmas de relação entre governo e Congresso e, portanto, diferentes níveis de governabilidade.

Por que isso teria ocorrido? Indo além, por que esse fenômeno acontece com governos que operam sob as mesmas regras? Explicações institucionais são suficientes? A seguir, será discutida uma hipótese explicativa menos trivial para esses eventos, sem a pretensão de que seja única, tampouco definitiva. 


\section{ESTILO DE GOVERNAR E GOVERNABILIDADE}

A partir da análise dos mandatos dos presidentes brasileiros que governaram de 1995 a 2016, este estudo dialoga com o que se chamou de ondas explicativas do presidencialismo de coalizão. O trabalho com dados e o percurso analítico desenvolvidos aqui foram orientados pela hipótese de pesquisa segundo a qual diferentes estilos de governar geram diferentes níveis de governabilidade.

Conforme apresentado, a literatura analisa o presidencialismo de coalizão brasileiro sob duas principais abordagens. A primeira enxerga a combinação institucional como um barril de pólvora, com forte tendência à instabilidade, à paralisia decisória e até à ruptura democrática (ABRANCHES, 1988; AMES, 2001; PEREIRA; MULLER, 2002; ANASTASIA, 2004). A outra corrente, por sua vez, argumenta que o próprio sistema é dotado de instrumentos capazes de promover a coordenação entre os Poderes e garantir a condução do governo (FIGUEIREDO; LIMONGI, 1998. FIGUEIREDO, 2001; SANTOS, 2002; RENNÓ, 2006; PEREIRA; MELO, 2012).

Neste trabalho, propõe-se a consideração de uma terceira onda explicativa, que não estaria exclusivamente relacionada ao sistema político brasileiro, mas aos presidencialismos em geral. Essa abordagem trata o perfil do presidente e do núcleo central com variável importante para os resultados políticos (BARBER, 1972; NEUSDAT, 1990; GREENSTEIN, 2000; SIAVELIS, 2010; ALESANDRO, 2013, 2014; LASSANCE, 2015).

O exame dos dados, que indica abalo na governabilidade nos mandatos a partir de 2010, especialmente após 2014, traz indícios de uma explicação menos trivial para o fenômeno. Há sinais de que alguma característica inerente ao período dos mandatos de Dilma tenha contribuído para a estremecimento da relação com o Congresso, interrompendo o equilíbrio que vinha se mantendo até então.

Desse modo, um dos elementos mais visíveis e que certamente foi único em cada um dos governos é o seu núcleo central, entendido como o/a presidente/a e sua equipe mais próxima - o motorista. Em grande medida, a composição do centro decisório foi diferente inclusive em cada um dos mandatos do mesmo presidente. Desse modo, defende-se que tal fator repercutiu no modus operandi de cada governo, em especial na articulação e coordenação política entre Executivo e Congresso, gerando reflexos nos níveis de governabilidade. Ou seja, diferentes perfis de governança resultaram em 
diferentes capacidades de condução do governo. O foco aqui não é, portanto, o perfil psicológico individual do presidente.

Logo, considerando que os indicadores utilizados são sinalizadores do nível de governabilidade, os resultados obtidos indicam variação na dinâmica da relação com o Congresso durante os governos, sendo a maior dificuldade observada nos mandatos de Dilma, em especial o segundo, justamente o momento em que a crise política atingiu o seu auge.

No período, o sucesso das propostas normativas, a estabilidade ministerial e a disciplina e satisfação da base estiveram especialmente comprometidos, além de terem seus efeitos potencializados pela forte fragmentação partidária. A gestão da coalizão, portanto, não foi bem-sucedida. Como essa função compete ao núcleo duro, a atuação do grupo não gerou os resultados esperados em termos de articulação entre os Poderes, conduzindo ao enfraquecimento da lealdade parlamentar em relação à presidenta ${ }^{6}$.

A partir da teoria utilizada e do estudo empírico desenvolvido, a proposta explicativa que se coloca aqui é, em primeiro lugar, que o perfil de governança dos presidentes importa, assim como sua trajetória pregressa. A capacidade de negociar com o Parlamento está associada à sua própria visão do sistema político. Por exemplo, presidentes com experiência parlamentar tendem a ser mais propensos a se aproximarem do Legislativo. Como o boss não conduz o mandato sozinho, o núcleo central como um todo impõe seu estilo ao mandato, o que gera resultados políticos, de maior ou menor intensidade.

Esse centro de governo, que, além do presidente, é formado por assessores inclusive os informais - e ministros com papéis ligados à coordenação técnica e política, está à frente da relação com os diversos atores, como os outros Poderes, os partidos, a burocracia, os demais ministros, os movimentos sociais e a mídia. Logo, sua função vai muito além do suporte ao presidente, na medida em que representam a "cara" do governo para dentro e para fora. Seu perfil e estilo de condução, portanto, têm reflexo nos rumos trilhados pela gestão.

\footnotetext{
${ }^{6}$ Para investigar melhor os diferentes padrões de relacionamento com o Congresso em cada governo, solicitou-se, em 07/11/2016, com base na Lei de Acesso à Informação, acesso ao banco das agendas presidenciais oficiais de FHC, Lula e Dilma, para uma comparação da frequência de compromissos com parlamentares em cada mandato. Em resposta, o Planalto não enviou os dados, informando que os de Dilma poderiam ser acessadas no site - o que não procede, visto que não estão completos nem organizados -, enquanto os de FHC e Lula deveriam ser demandados aos institutos dos ex-presidentes.
} 
Nesse sentido, as explicações institucionalistas não rivalizariam com a aqui proposta, mas seriam todas complementares. A aparente oposição entre as teorias pode estar relacionada ao fato de a literatura, em geral, supervalorizar as instituições formais, deixando de lado as regras tácitas e informais fundamentais no jogo político, especialmente na relação entre Executivo e Legislativo.

De fato, a complexidade do contexto em que a crise político-institucional está inserida torna difícil o isolamento de uma ou outra variável, ou a atribuição de força explicativa a apenas uma delas. Por outro lado, é simplista supor que fatores econômicos ou geopolíticos, por exemplo, respondam por toda a performance dos governos.

Em entrevista concedida em 13 de maio de 2016, Ames reavaliou suas conclusões anteriores à luz da crise atual. No seu estudo emblemático (AMES, 2001), ele havia defendido que o sistema político brasileiro é lento, dispendioso e propenso ao caos em decorrência do seu arcabouço institucional. Durante o segundo mandato de Lula e na transição para Dilma, segundo ele, seus argumentos passaram a soar fracos, pois o Congresso havia aprovado os principais projetos, os líderes partidários controlavam suas bancadas e os órgãos de combate à corrupção estavam funcionado.

Ele analisa, todavia, que seu ponto não era desprovido de fundamento, pois avalia que a expansão econômica combinada à habilidade de Lula possa ter ocultado a debilidade das instituições políticas brasileiras. No entanto, ele afirma ter desconsiderado alguns elementos importantes para a compreensão da engenharia do sistema e da instabilidade política atual.

Para Ames (2016), reformas políticas ajudarão no longo prazo, mas o Brasil enfrenta mais que um problema de regras políticas: a crise é mais complexa e mais profunda. Segundo ele, os ingredientes são de naturezas diversas: i) contexto de desaceleração econômica internacional, e não apenas interna; ii) inabilidade política de Dilma; iii) clientelismo e perniciosa relação histórica das empreiteiras com o poder público; iv) falta de credibilidade do Congresso, que opera na administração do clientelismo e da corrupção.

Também com o propósito de construir explicações para crise, este estudo demonstra que há fortes indicativos da existência de explicações intrínsecas às gestões para a compreensão das diferentes capacidades de governar. Há o solo de sustentação do presidencialismo de coalizão, formado por suas instituições, que precisa ser percorrido para a geração de resultados políticos, como uma pista. Em seguida, existe o carro que 
trafega pela pista institucional do sistema político, superando seus buracos, curvas e obstáculos. Por fim, há o conjunto de atores centrais que manejam os instrumentos de coordenação, refletidos na figura do motorista.

Esse personagem tem importante papel na condução do governo, na medida em que define o seu perfil de governança, influenciando os outputs gerados pelos diferentes processos. Nesse sentido, o argumento é que o presidencialismo de coalizão não é o mesmo para todos os presidentes, indicando que o perfil dos atores importa para os resultados políticos. 


\section{CONSIDERAÇÕES FINAIS}

O Brasil vive hoje um conjunto de crises - política, econômica, social e institucional -, o que torna mais difícil a identificação e isolamento dos fatores responsáveis pela situação atual. De todo modo, especialmente nos últimos anos, a relação Executivo e Legislativo demonstra-se cada vez mais ineficiente - mais cara e mais fraca -, tendo chegado ao ápice do seu acirramento a partir de 2014, sobretudo em 2016. Naquela ocasião, Dilma enfrentou ainda maior dificuldade para dar andamento aos seus projetos e governar de fato, tendo ao final sofrido um processo de impeachment.

As principais instituições do presidencialismo de coalizão estão vigentes e consolidadas desde a Constituição de 1988, especialmente a partir de 1995. Ou seja: as regras do jogo são praticamente as mesmas desde então, mas a crise é um fenômeno mais recente. Desse modo, a explicação institucionalista - de que os resultados políticos decorrem das regras - parece não cobrir todo o fenômeno da interrupção do equilíbrio.

A questão central que orientou este trabalho foi, portanto: nos mandatos $F H C$, Lula e Dilma, quais os indicativos e as causas das mudanças no padrão de relacionamento com o Congresso, que refletiram na governabilidade e desencadearam a crise política?

O hemograma aqui construído parte do que diz a literatura, de maneira esparsa e desagregada, sobre elementos indicativos da governabilidade, além de adicionar alguns ingredientes novos. Nesse sentido, foram analisadas, basicamente, dimensões ligadas i) às propostas legislativas; ii) às características da coalizão; iii) à dinâmica da composição ministerial; e iv) à fragmentação partidária.

A análise dos resultados indica que algum aspecto intrínseco aos governos afetou a relação entre os Poderes e, consequentemente, a governabilidade. Nesse sentido, circunstâncias não institucionais operaram para a interrupção do equilíbrio do sistema a partir de 2011, em especial após 2014, pois a capacidade de governar estava particularmente afetada durante a gestão presidencial daquele período.

Os achados de pesquisa deste trabalho podem ser lidos, portanto, como indícios de que a redução da governabilidade tem alguma relação com explicações não exclusivamente institucionalistas, mas que levem em conta não a personalidade individual do presidente, e sim o estilo de governança do núcleo duro de governo como um todo. Nessa perspectiva, estão considerados, por exemplo, a forma de articulação com 
o Congresso, o perfil de gestão, a maneira de condução dos processos decisórios e a comunicação política conduzidos pelo grupo central de governo.

Esse fator seria não propriamente a personalidade individual da presidenta, mas do núcleo central de governo - o qual, em grande medida, tende a reproduzir o perfil do boss. Tal estilo está presente em diversos aspectos de atuação, como gestão, comunicação, liderança e articulação política.

Além disso, há outro elemento que pode ter contribuído para o abalo do sistema, e que esse sim parece ter a ver especificamente com o perfil da própria presidenta: a existência de um sistema de combate à corrupção funcionando de verdade, o que parece mais evidente a partir do governo Dilma, que permitiu - ou, no mínimo, não interferiu que as instituições de enfrentamento à corrupção operassem efetivamente. É possível que, no limite, talvez o presidencialismo de coalizão não consiga manter seu equilíbrio sem a dinâmica da corrupção.

A explicação que se propõe aqui é de natureza comportamentalista. Além de fatores políticos e institucionais, o papel dos atores influenciou a dinâmica da crise. $\mathrm{O}$ estilo do presidente, do seu gabinete e dos seus líderes no Congresso são importantes elementos para que sejam adequadamente utilizados os instrumentos de coordenação institucional e de articulação política. Esse aspecto estaria relacionado não apenas à liderança e à capacidade de articulação, mas à propensão à condução das mais diferentes negociações - inclusive aquelas moral e legalmente questionáveis - para a construção e manutenção do apoio legislativo.

Dependendo do peso do estilo presidencial nos resultados políticos - algo altamente complexo e desafiador de ser medido - talvez exista de fato um problema com as instituições que compõem o "presidencialismo de coalizão", pois o pressuposto de toda e qualquer instituição é que seu funcionamento independa dos atores que atuam sob ela.

Evidentemente, ainda que as regras do jogo e as ferramentas gerenciais sejam as mesmas, "as pessoas" não representam as únicas peculiaridades de um governo. Cada presidente operou, por exemplo, dentro de um contexto específico, como o ambiente econômico e a geopolítica internacional, o que influencia as decisões dos atores e os resultados políticos. Além disso, há fatores de ordem sociológica, que também podem ser explorados para a comparação das performances dos governos.

Há que se considerar também que, sendo a governabilidade um fenômeno altamente complexo e inserido num contexto de múltiplas crises, é difícil isolar 
determinadas variáveis e afirmar categoricamente que outras causas não estariam presentes nas explicações para a interrupção do equilíbrio. O país está assolado em uma grave crise econômica e tem vivenciado, por exemplo, os efeitos da Operação Lava-Jato, que alcançou a classe política de forma ampla. Tais fatores certamente rebatem sobre a estabilidade política, comprometendo a governabilidade.

De 2010 em diante, por exemplo, o Brasil passou a sentir os efeitos da crise econômica mundial. A partir de 2009, na tentativa de segurar o nível de emprego, o governo atuou de maneira agressiva, realizando ampla desoneração de tributos e adotando medidas anticíclicas com o gasto público. Isso foi gerando inflação cada vez maior, mesmo com a contenção dos preços de gasolina, energia e tarifas públicas.

O índice de inflação, que havia sido de 4,31\% em 2009, fechou 2010 já em 5,91\%, 6,5 em $2011 \%$ e, nos anos seguintes, continuou gerando em torno dos $6 \%$, chegando a 10,67\% em 2015. De 2010 para 2011, o PIB caiu de 7,53 para 3,97\%, fechando em 1,92\% em 2012, 3\% em 2013, 0,5\% em 2014 e -3,77\% em 2015 . Em 2014, portanto, a economia já mal crescia e a inflação já extrapolava a meta. Em 2015, o governo tentou fazer um ajuste, soltando os preços e aumentando os juros, o que provocou estagflação. Ainda que os efeitos do desemprego tenham sido percebidos mais fortemente em 2016, a população sentia o aumento de preços e os setores econômicos se preocupavam cada vez mais com o descontrole da economia.

Além da crise econômica, outro evento importante ocorrido no período foi a onda de denúncias de corrupção que afetou a classe política, especialmente no âmbito da Operação Lava-Jato. Tal fato parece ter comprometido a estabilidade, visto que teve alcance bastante amplo sobre partidos, políticos e grandes empresas.

Sobre esses ingredientes contextuais, duas ponderações merecem ser feitas. Em primeiro lugar, este estudo não defende a desconsideração desses fatores de ordem econômica, sociológica e institucional, que aliás não devem ser descartados - e, em geral, a literatura não o faz - na análise de nenhum fenômeno político. Igualmente, o isolamento metodológico e o teste desse tipo de variável, sobretudo as de natureza econômica, é uma tarefa bastante sofisticada, complexa e com limitações de generalização, o que não significa que as pesquisas não devam tentar avançar nesse desafio.

${ }^{7}$ Dados do Ipeadata. Acesso em 27/02/2017. 
Este trabalho teve o propósito de contribuir para o debate sobre o presidencialismo de coalizão brasileiro, basicamente, i) fazendo uma análise quantitativa da capacidade de governar das gestões presidenciais que antecederam a situação política atual, ii) apresentando nova ferramenta metodológica para a medição da governabilidade e iii) reforçando a hipótese de explicações comportamentalistas para a atual crise e para os fenômenos políticos em geral.

Desse modo, esta pesquisa pretende contribuir como ponto de partida, e não de chegada, para a análise do fenômeno. Espera-se que, a partir do levantamento de dados realizado e da proposta explicativa lançada, o estudo agregue elementos à agenda de pesquisa sobre a crise política brasileira, bem como o papel das instituições e dos atores nos resultados políticos. 


\section{REFERÊNCIAS BIBLIOGRÁFICAS}

ABRANCHES, Sérgio Henrique Hudson de. Presidencialismo de coalizão: o dilema institucional brasileiro. Dados. Revista de Ciências Sociais. Rio de Janeiro, vol. 31, n. 1, p. 5-34, 1988.

, Sérgio. Os ciclos do presidencialismo de coalizão. Ecopolítica. 11 março

2014.

ALESANDRO, Martín. The role of the center of government / Martín Alessandro, Mariano Lafuente, Carlos Santiso. 2013

ALESANDRO, Martín. Gobernar para cumplir con los ciudadanos: el rol del Centro de Gobierno en América Latina y el Caribe / Martín Alessandro, Mariano Lafuente, Carlos Santiso. 2014

AMES, Barry. Os entraves da democracia no Brasil. Rio de Janeiro: Fundação Getúlio Vargas, 2003.

, Barry. Os entraves da democracia no Brasil: uma crise antevista?: Folha de S. Paulo: São Paulo, 22 de maio de 2016.

AMORIM NETO, Octavio. Gabinetes Presidenciais, Ciclos Eleitorais e Disciplina Legislativa no Brasil. Dados v.43 n.3 Rio de Janeiro 2000.

, Octavio. De João Goulart a Hugo Chávez: A política venezuelana à luz da experiência brasileira. Opin. Publica [online]. 2002, vol.8, n.2, pp. 251-274.

Octavio; COX, Gay; MACCUBBINS; Mathew. Agenda Power in

Brazil's Câmara dos Deputados, 1989-1998. World Politics 55(4), p. 550-578, 2003.

, Octavio. El presidencialismo moderno em Brasil. Parlamentarismo e Presidencialismo. Presidencialismo y Parlamentarismo. Madrid, 2012.

ANASTASIA, F., MELO, C. R. e SANTOS, F. Venezuela: um país dividido. In: Governabilidade e representação política na América do Sul. Rio de Janeiro/São Paulo: Konrad-Adenauer-Stiftung/Unesp, 2014

ARAÚJO, Victor. Multipartidarismo, Coordenação de Preferências e PolicePatrol em Sistemas Presidencialistas. São Paulo, 2015.

BRITTO, Luiz Navarro de. A Representação Proporcional. Revista Brasileira de Estudos Políticos, n $19,1965$.

BARBER, James David. The Presidential Character: Predicting Performance in the White House. 2nd Edition. London: Prentice Hall International Inc, 1972.

BÚRIGO, Vandré Augusto. Sistema eleitoral brasileiro - a técnica de representação proporcional vigente e as propostas de alteração: breves apontamentos. Revista de Informação Legislativa, n.154, p.179, abr/jul. 2002 
CHEIBUB, José Antônio, PRZEWORSKI, Adam, and SAIEGH,Sebastian. Government Coalition and Legislative Effectiveness under Parliamentarism and Presidentialism. British Journal of Political Science, vol. 34, p 259-285, 2004.

José Antônio. FIGUEIREDO, Argelina; LIMONGI, Fernando. Partidos políticos e governadores como determinantes do comportamento legislativo na câmara dos deputados, 1988-2006. Dados, Rio de Janeiro, v. 52, n. 2, June 2009.

José Antonio; PRZEWORSKI Adam; SAIEGH, Sebastian. Governos de Coalizão nas Democracias Presidencialistas e Parlamentaristas. In: DADOS - Revista de Ciências Sociais, Rio de Janeiro, Vol. 45, n², 2002, pp. 187 a 218.

DEHEZA, Grace Ivana. Gobiernos de coalicion en el sistema presidencial: America del Sur. In: Nohlen, Dieter e Fernandez, Mario (orgs.) El presidencialismo renovado: Institucionalismo y cambio político en América Latina. Caracas: Nueva Sociedad, 1998.

FREITAS, Andrea Marcondes de. O presidencialismo da coalizão. USP: 2013, São Paulo.

GEORGE, Alexander L. Assessing Presidential Character. Cambridge University Express. Vol. 26, No. 2 (Jan., 1974), pp. 234-282.

GREGGIANIN, Eugênio; SILVA, José de Ribamar Pereira da. O Orçamento Impositivo das Emendas Individuais - Disposições da Emenda Constitucional $n^{\circ}$ 86, de 2015, e da LDO 2015. Orçamento em discussão. Brasília, 2015.

HALL, Peter \& TAYLOR, Rosemary. (1996), Political Science and the three new institutionalism. Political Studies, 44 (5): 936-957.

HELMKE, Gretchen; LEVITSKY, Steven. Informal institutions and comparative politics: a research agenda. Kellog Institute, 2013.

HERMAMN, Valentine; MENDEL, Françoise. Parliaments of the world: a reference compendium. London: Inter-Parliamentary Union/De Gruyter, 1976.

IDEA, Manual internacional IDEA sobre diseño de sistemas electorales, Estocolmo, Idea, 1997.

INÁCIO, Magna; LLANOS, Mariana. The Institutional Presidency from a Comparative Perspective: Argentina and Brazil since the 1980s. Brazilian Political Science Review, 2015.

LAMEIRO, Camila Romero. A Casa Civil e a coordenação governamental do Executivo Federal (1995-2010). CONSAD. Brasília, 2014.

LASSANCE, Antonio. Governança presidencial e desenvolvimento: o poder dos Presidentes. Presidencialismo no Brasil: história, organização e funcionamento. Brasília, 2015. 
LEMOS, Leany Barreiro de Sousa. O Congresso brasileiro e a distribuição de benefícios sociais no período 1988/1994: uma análise distributivista. Dados. 44(3), 2001, pp. 561604, 2001.

; RICCI, Paolo. Individualismo e partidarismo na lógica parlamentar: o antes e o depois das eleições. In: POWER, T.; ZUCCO, C. (orgs.). O Congresso por ele mesmo: autopercepções da classe política brasileira. Belo Horizonte: Editora UFMG, 2011.

LIMONGI, Fernando. A democracia no Brasil: presidencialismo, coalizão partidária e processo decisório. In: CEBRAP no.76 São Paulo Nov. 2006

; FIGUEIREDO, Argelina C. O Processo Legislativo e a Produção Legal no Congresso Pós-Constituinte. Novos Estudos Cebrap, no 38, março. 1995.

As Bases Institucionais do Presidencialismo de Coalizão. Lua Nova. Revista de Cultura e Política, São Paulo, v. 44, p. 81-106, 1998.

LYONS, Michael. Presidential Character Revisited. Political Psychology. Vol. 18, N. 4. Lund, 1997.

MAHONEY, James. 2002. Chapter 1: Explaining Political Development in Central America. In The Legacies of Liberalism: Path Dependence and Political Regimes in Central America, 3-28. Baltimore: The Johns Hopkins University Press.

MAINWARING, Scott. Presidentialism and Democracy in Latin America. University of California, San Diego, 1997.

MELO, Carlos Ranulfo. As instituições brasileiras funcionam? Rev. Sociol. Polít., Curitiba, 25, p. 199-203, nov. 2005.

MOISÉS, José Álvaro. O Desempenho do Congresso Nacional no Presidencialismo de Coalizão (1995-2006). In: O papel do Congresso Nacional no presidencialismo de coalizão / [organizado por: José Álvaro Moisés]. - Rio de Janeiro: Konrad-AdenauerStiftung, 2011

NEUSTADT, R. E. Presidential power and the modern presidents. New York: The Free Press, 1990.

NICOLAU, Jairo. Disciplina Partidária e Base Parlamentar na Câmara dos Deputados no Primeiro Governo Fernando Henrique Cardoso (1995-1998). In: Dados vol.43 no.4 Rio de Janeiro, 2000.

, Jairo. Sistemas Eleitorais. 5aed. Rio de Janeiro: FGV Editora, 2004.

PEREIRA, Carlos; MELO, Marcus André. The Surprising Success of Multiparty Presidentialism. Journal of Democracy. 23 (3): 156-70, 2012.

POWELL, G.B. Elections as Instruments of Democracy. Majoritarian and Proportional Visions. New Haven: Yale University Press. 2000. 
POWER, Thimothy. O presidencialismo de coalizão na visão dos parlamentares brasileiros. In: O Congresso por ele mesmo: autopercepção da classe política brasileira. Editora UFMG: Belo Horizonte, 2011.

REBELLO, Maurício Michel. A fragmentação partidária no Brasil: visões e tendências. $36^{\circ}$ Encontro Anual da ANPOCS

RENNÓ, Lucio Remuzat; PEREIRA FILHO, Carlos Eduardo Ferreira. Gastos Públicos, Emendas Orçamentárias do Legislativo e Inclusão Dissipativa nos Municípios Brasileiros: 1998 a 2010. Brasília, 2013.

RICCI, Paolo. O conteúdo da produção legislativa brasileira: leis nacionais ou políticas paroquiais? Dados, Rio de Janeiro, v. 46, n. 4, p. 699-734, 2003.

SANTOS, Fabiano. Em defesa do Presidencialismo de Coalização. IN: Reforma Política no Brasil - Realizações e Perspectivas. Fortalieza, Fundação Konrad Adenauer, 2003, p. 19-38.

, Fabiano; VILAROUCA, Márcio Grijó. Political institutions and governability from FHC to Lula. In: Democratic Brazil Revisited. University Pittburgh Press. Pittburgh, 2008.

SANTOS, Wanderley Guilherme dos. Sessenta e quatro: anatomia da crise. São Paulo, Vértice, 1986.

SIAVELIS, P. Formal and Informal Organization of the Executive Branch in Chile. In $V$ Congreso Latinoamericano de Ciencia Politica. Buenos Aires, 2010.

SCHMIDT, Vivian. Discursive Institutionalism: The Explanatory Power of Ideas and Discourse. Annual Review of Political Science, 11(303-326), 2008.

TSEBELIS, George.Jogos Ocultos: Escolha Racional no Campo da Política Comparada. Edusp. Capítulo 2 (Em defesa do enfoque da Escolha Racional), 1998. 